Rolf v. Lüde (Hg.)

\title{
Neue Wege der
}

\section{Hochschulgovernance}

Symposium zum Hochschulmanagement an der Fakultät Wirtschafts- und Sozialwissenschaften der Universität Hamburg 

Rolf v. Lüde (Hg.)

Neue Wege der Hochschulgovernance 
Fakultät Wirtschafts- und Sozialwissenschaften 
Rolf v. Lüde (Hg.)

\section{Neue Wege der Hochschulgovernance}

Symposium zum Hochschulmanagement

an der Fakultät Wirtschafts- und Sozialwissenschaften

der Universität Hamburg

Mit Beiträgen von

Rolf v. Lüde, Hans E. Roosendaal und Kasia Zalewska-Kurek, Barbara Sporn, Hans-Ulrich Küpper und Wolfgang Weber

Hamburg University Press

Verlag der Staats- und Universitätsbibliothek Hamburg Carl von Ossietzky 
Impressum und Bildnachweis

Bibliografische Information der Deutschen Nationalbibliothek

Die Deutsche Nationalbibliothek verzeichnet diese Publikation in der Deutschen Nationalbibliografie; detaillierte bibliografische Daten sind im Internet über http://dnb.d-nb.de abrufbar.

Die Online-Version dieser Publikation ist auf den Verlagswebseiten frei verfügbar (open access). Die Deutsche Nationalbibliothek hat die Netzpublikation archiviert. Diese ist dauerhaft auf dem Archivserver der Deutschen Nationalbibliothek verfügbar.

Open access über die folgenden Webseiten:

Hamburg University Press - http://hup.sub.uni-hamburg.de PURL:

http://hup.sub.uni-hamburg.de/purl/HamburgUP_Luede_Hochschulgovernance Archivserver der Deutschen Nationalbibliothek - http://deposit.d-nb.de

ISBN 978-3-937816-73-9

(C) 2010 Hamburg University Press, Verlag der Staats- und Universitätsbibliothek Hamburg Carl von Ossietzky, Deutschland

Covergestaltung: Benjamin Guzinski, Hamburg

Abbildung auf dem Cover: Foyer des Hauptgebäudes der Universität Hamburg, Edmund-Siemers-Allee 1; Foto: UHH/Schell.

Produktion: Elbe-Werkstätten GmbH, Hamburg, Deutschland http://www.ew-gmbh.de 
Inhalt

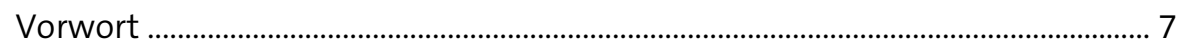

Alexander Bassen

Neue Governance der Wissenschaft 9 Rolf v. Lüde

The central-decentral paradox 23

The university as a merging organisation

Hans E. Roosendaal and Kasia Zalewska-Kurek

Steuerung autonomer Universitäten: Erfahrungen mit der österreichischen Universitätsreform

Barbara Sporn

Steuerungsinstrumente für Hochschulen 61

Hans-Ulrich Küpper

Das letzte Wort 91

Wolfgang Weber

Verstaltungsprogramm 97

Beitragende 99 



\section{Vorwort}

Mit dem Gesetz zur Bildung der Fakultät Wirtschafts- und Sozialwissenschaften der Universität Hamburg (WiSoG) vom 8. Februar 2005 beschritt der hamburgische Gesetzgeber in vielerlei Hinsicht Neuland. Mit Wirkung vom 1. April 2005, so heißt es in Paragraf 2 des WiSoG, bildet die bisherige HWP gemeinsam mit den bisherigen Fachbereichen Wirtschaftswissenschaften und Sozialwissenschaften der Universität Hamburg die neue Fakultät Wirtschafts- und Sozialwissenschaften. Vermutlich ist die WiSo-Fakultät eine der ganz wenigen Fakultäten, vielleicht sogar die einzige Fakultät, die durch ein eigenes auf sie zugeschnittenes Gesetz gegründet und mit deren Gründungsakt gleichzeitig die Eigenständigkeit einer ganzen Universität beendet wurde. Auch bezüglich ihrer Leitungsstruktur weist die neue Fakultät Besonderheiten auf, die sie deutlich von bisherigen Strukturen unterscheiden. Die neue Fakultät, die sich in die drei Departments Wirtschaftswissenschaften, Sozialwissenschaften und Wirtschaft und Politik gliedert, wird von einem hauptamtlichen Gründungsdekan sowie je einem Prodekan aus den Departments und einem ebenfalls hauptamtlichen Geschäftsführer geleitet. Wichtigstes beschlussfassendes Organ ist der Gründungs-Fakultätsrat.

Das Ende der Gründungsphase nach dreieinhalb Jahren am 30. September 2008 und die Überführung der Fakultät in die "Normalität“ als eine von sechs Fakultäten der Universität Hamburg, vorbereitet durch eine durch den Gründungs-Fakultätsrat einstimmig verabschiedete neue Fakultätssatzung, ist ein willkommener Anlass, die neuen Management-Prinzipien, die im WiSo-Gesetz zum Ausdruck kommen, zum Gegenstand eines wissenschaftlichen Symposiums zu machen. Ziel dieses Symposiums vom 16. Oktober 2008 war es, unterschiedliche Governance-Modelle, vor allem aus dem europäischen Ausland, einander gegenüberzustellen und diese sowohl aus einer erfahrungsbasierten Leitungsperspektive als auch unter wissenschaftlich-analytischen Sichtweisen zu bewerten. Es gelang, Kolleginnen und Kollegen aus dem In- und Ausland für dieses Symposium zu gewinnen, die in ihrer Person sowohl diese Leitungserfahrung verkörpern als auch mit eigenen Forschungen zu Hochschule und Governance hervorgetreten sind. Allerdings sind nicht alle Beiträge, die auf dem Symposium gehalten wurden, auch hier veröffentlicht. 
Prof. Dr. Barbara Sporn, Vizerektorin für Forschung, Internationales und External Relations der Wirtschaftsuniversität Wien, berichtet in ihrem Beitrag „Steuerung autonomer Universitäten“ über Erfahrungen mit der österreichischen Universitätsreform. Prof. Dr. Ernst Buschor, Mitglied der Regierung des Kantons Zürich (1993-2003), Vizepräsident der Schweizer Universitätskonferenz (2001/2002) und ehemaliger Vizepräsident des Rates der Eidgenössischen Technischen Hochschulen (ETH), stellte unter dem Titel „Das Schweizer Hochschulrecht vor der Novellierung“ die Weiterentwicklung der Hochschulreform auf dem Symposium vor. Prof. Dr. Hans Roosendaal, Professor for Strategic Management an der University of Twente/ Niederlande und ehemaliger Vizepräsident dieser Hochschule, greift zusammen mit Dr. Kasia Zalewska-Kurek mit „The central-decentral paradox: The university as a merging organization" ein Thema auf, das trotz der vollzogenen Integration an der WiSo-Fakultät alle in diesen Prozess eingebundenen Akteure sicher auch in Zukunft weiter beschäftigen wird. Prof. Dr. Dr. h. c. Hans-Ulrich Küpper, Institut für Produktionswirtschaft und Controlling, Ludwig-Maximilians-Universität München, und Leiter des Bayerischen Staatsinstituts für Hochschulforschung und Hochschulplanung, untersucht in seinem Beitrag „Moderne Steuerungsinstrumente für Hochschulen“ das Instrumentarium zur Steuerung von Hochschulen auch in seinen notwendigen Unterschieden zu Steuerungsmodellen von Wirtschaftsunternehmen.

Eingebettet sind diese Beiträge unserer auswärtigen Gäste in grundlegende Überlegungen des Forschungsdekans in der Gründungsphase und Herausgeber dieses Bandes, Prof. Dr. Rolf v. Lüde, zur „Neuen Governance der Wissenschaft" sowie dem „Letzten Wort" des Gründungsdekans der WiSo-Fakultät, Prof. Dr. Dr. h. c. mult. Wolfgang Weber. Dieses Symposium, mit dem die WiSo-Fakultät gleichzeitig auch ihrem Wirken und persönlichem Engagement in der Gründungsphase dankt, möge dazu beitragen, das Handeln aller verantwortlichen Akteure in dieser Fakultät auch in Zukunft stets so zu reflektieren, wie dies in den vorliegenden Beiträgen an ganz unterschiedlichen Universitäten in verschiedenen Ländern zum Ausdruck kommt. Allen, die zum Gelingen dieses Symposiums beigetragen haben, sei hier herzlich gedankt.

Im Juni 2009

Prof. Dr. Alexander Bassen

Kommissarischer Dekan der WiSo-Fakultät 
Neue Governance der Wissenschaft

Rolf v. Lüde

1 Die Gründung der WiSo-Fakultät und ihre drei „kulturellen Gegenwarten“

Vor ein paar Tagen, am 30. September 2008, ist die Gründungsphase der Fakultät Wirtschafts- und Sozialwissenschaften der Universität Hamburg, einer der größten Fakultäten dieses Typs in Europa überhaupt, endgültig zu Ende gegangen. Als wir vor circa einem Jahr im Dekanat zum ersten Mal darüber nachgedacht haben, ob und wie wir dieses eigentlich schon für den 31. März 2008 vorgesehene Ereignis begehen sollten, das ja zugleich auch das Ende der Amtszeit des Gründungsdekanats und vor allem auch des ersten hauptamtlichen Gründungsdekans in Hamburg, möglicherweise sogar Deutschlands, bedeutete, haben wir uns relativ schnell dazu entschlossen, statt einer großen Feier, die ebenfalls nahegelegen hätte, unser eigentliches Metier, die Wissenschaft, zu nutzen und unser praktisches Handeln als Dekanat einem wissenschaftlichen Diskurs zu unterziehen und gleichsam selbstreferentiell unter Beachtung der Umweltbedingungen, also zum Beispiel neuer Hochschulgesetze, unser Handeln zu reflektieren. Damit verbunden war auch die Überlegung, sich nach der Gründungsphase dieser Fakultät, die ja ebenfalls mit einem Auftaktsymposium im Jahr 2005 in Travemünde begonnen hatte, für einen Tag dem Alltagsgeschäft des ständigen „Entscheiden-Müssens" zu entziehen und sich die Zeit, organisationstheoretisch den "slack“, das meint Schlupf oder Stillstand, zu gönnen, deren es bedarf, um über eigenes Handeln und Zielperspektiven gemeinsam nachzudenken.

Ganz bewusst haben wir jedoch keine Auseinandersetzung mit spezifischen und aktuellen Hamburger Entwicklungen, Problemen und Konflikten geplant. Vielmehr sollen die herausfordernden Bedingungen, unter denen diese Gründungsphase stattfand, unter einer erweiterten Perspektive 
zum Gegenstand eines erfahrungsbasierten wissenschaftlichen Symposiums werden. Die gesetzlichen Rahmenbedingungen haben sich nicht nur für Hamburg, sondern für alle Hochschulen in Deutschland, aber auch in seinen Nachbarländern, in den letzten Jahren erheblich verändert - mit weitreichenden Konsequenzen für die innere Organisation der Universität ebenso wie für Forschung, Lehre und Lernen.

Die WiSo-Fakultät der Universität Hamburg wurde, wohl einzigartig in Deutschland, mit einem eigenen Gesetz gegründet (WiSoG 2005). Verbunden damit war die Herausforderung einer ja nicht ganz freiwilligen Integration ich weiß, dass diese schwache Umschreibung einen starken Euphemismus darstellt - einer ganzen Hochschule mit einem explizit eigenständigen Profil, der ehemaligen Hamburger Universität für Wirtschaft und Politik, sowie der bis dahin eigenständigen Fachbereiche Wirtschaftswissenschaften und Sozialwissenschaften mit ganz unterschiedlichen Wissenschafts- und Lehrkulturen. Diese neue Fakultät stand und steht in diesem Reorganisationsprozess nicht nur unter besonderer Beobachtung der Politik, des Hochschulrates und des eigenen Präsidiums, sondern auch vor Herausforderungen für die Schaffung neuer organisationaler Strukturen, insbesondere eines neuen Selbstverständnisses und einer Kultur, die es allen Beteiligten ermöglichen sollten, diese Kultur und dieses neue Selbstverständnis, zumindest ein Stück weit, als die ihre anzusehen und mit Leben zu erfüllen.

Bei Organisationen, so Luhmann, handelt es sich um „nicht kalkulierbare, unberechenbare, historische Systeme", die jeweils von einer Gegenwart ausgehen, die sie selbst erzeugt haben (Luhmann 2000, S. 9). Damit ist gemeint, dass die Organisationen die Bedingungen, unter denen sie arbeiten, selbst erschaffen, eine Aussage, die zunächst Widerspruch auslösen mag, wenn man etwa an die äußeren Zwänge denkt, denen zum Beispiel unsere Fakultät und die Organisationen, aus denen sie hervorgegangen ist, ausgesetzt waren. Nach der systemtheoretischen Perspektive sind Organisationen jedoch autopoietische Systeme, die sich durch eigene Operationen selbst produzieren und reproduzieren und damit den „historischen $\mathrm{Zu}$ stand" herstellen, in dem sie sich in jedem Augenblick befinden. Dieser Befund gilt für alle Organisation. Wenn wir den Status quo ante unserer Fakultät auch unter Beachtung der unter anderem von Prof. Müller-Böling geleiteten Moderationsgespräche zur Integration dreier heterogener und eigenständiger Organisationen betrachten, können wir uns in dieser luh- 
mannschen Beschreibung auch als Fakultät wieder erkennen. Denkt man die ja viel prominentere und „im Himmel geschlossene“ Verbindung der beiden Großorganisationen Daimler und Chrysler, war die neue WiSo-Fakultät gleichsam mit drei differenten, historisch gewachsenen Gegenwarten konfrontiert, die ziemlich heftig aufeinanderprallten - und vom Himmel wollte schon gar keiner der beteiligten Akteure sprechen, so weit ging noch nicht einmal der damals federführende Senator.

Dieses autopoietische Verständnis von Organisation, bei dem es die Mitglieder selbst sind, die die inneren Strukturen herstellen, steht natürlich in deutlichem Gegensatz zu einem mechanistischen Verständnis von Organisationswirklichkeiten, bei dem unterstellt wird, dass man der Universität nur eine neue rechtliche Struktur verordnen müsse und damit auch schon deren Umsetzung sichergestellt sei. Als Wirtschafts- und Sozialwissenschaftler wissen wir natürlich, dass in einem solchen Prozess der inneren und äußeren Reorganisation mit enormen Problemen, die gemeinhin als Herausforderungen umschrieben werden, und vor allem mit nicht intendierten Nebenfolgen zu rechnen ist, die die von der Politik angestrebten Organisationsziele konterkarieren können. Dies gilt vor allem für Expertenorganisationen wie die der Universität, in denen es gleichsam zum Professionsverständnis der Akteure gehört, sich in den eigenen Weltbildern und Wahrnehmungsmustern nicht irritieren zu lassen und sich möglichst von organisationalen Zwängen zu befreien; eine Organisationswirklichkeit, die es den Mitgliedern eines Dekanats nicht gerade erleichtert, trotz vieler Diskurse eine kollektive Identität der Fakultät herzustellen. Kommunikationsfähigkeit und die Bereitschaft zum Diskurs sind deswegen, das sei hier nur am Rande erwähnt, neben einer hoher Frustrationstoleranz zentrale Voraussetzungen für dieses Amt.

Zwar hatten und haben wir es unter den oben skizzierten Bedingungen eines neuen Hochschulgesetzes und der drei „kulturellen Gegenwarten“ in unserer Fakultät mit besonderen Herausforderungen zu tun, die aber eingewoben sind in national und international neue Regime universitärer Governance, die sich bei Unterschieden im Detail gleichsam isomorph über alle Bundesländer ausgebreitet haben. Deshalb schien es uns für die heutige Veranstaltung zukunftsfähiger, über die Grenzen Hamburgs hinauszuschauen und Kollegen aus anderen Ländern zu bitten, uns von ihren Forschungen, ihren Erfahrungen, Bedenken und gegebenenfalls Dilemmata, in die sie möglicherweise unter ihren Governance-Regimen geraten sind, 
unter einer theoretischen, gleichwohl erfahrungsbasiert geleiteten Perspektive zu berichten. Ich bin überzeugt davon, dass kollektive Akteure, wie unsere Fakultät, daraus lernen können - und sei es auch nur Verständnis dafür zu entwickeln, dass die Probleme, mit denen wir uns herumschlagen, auch anderenorts zu Irritationen führen und dort andere, von uns abweichende Lösungsperspektiven ausprobiert werden.

\section{Der Governance-Begriff als einheitlicher Bezugsrahmen}

Damit wir einen einheitlichen Rahmen schaffen, haben wir das übergreifende Thema des Hochschulmanagements mit einem Fokus auf den „Neuen Wegen der Hochschulgovernance" gewählt.

Ich will zunächst kurz auf diesen Begriff und seine Bedeutung für das Management von Wissenschaft und Hochschulen eingehen. Ich kann mich dabei auf ein langjähriges, von mir geleitetes Schwerpunktprogramm-Projekt der Deutschen Forschungsgemeinschaft (DFG) stützen, dessen Ergebnisse gerade in einem 600-seitigen Band unter dem Titel "Selbstorganisation und Governance in künstlichen und sozialen Systemen" veröffentlicht werden (v. Lüde/Moldt/Valk 2009).

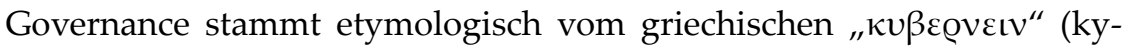
bernein) und vom lateinischen "gubernare" ab, womit ursprünglich das

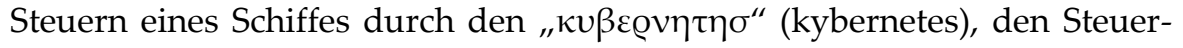
mann, gemeint war. Wenn man sich vergegenwärtigt, dass auch das Wort Risiko vom griechischen "อı $\alpha^{\prime \prime}$ (riza) abstammt und die Bedeutung hat, eine Klippe oder einen Fels zu umschiffen, dann wird schon aus dem gemeinsamen sprachlichen Ursprung deutlich, dass offensichtlich Governance und Risiko untrennbar miteinander verbunden sind, dem Risiko nämlich, eine innerorganisatorische Klippe nicht rechtzeitig erkannt zu haben.

Ausgehend von den 70er-Jahren des letzten Jahrhunderts herrschte die Vorstellung vor, dass man Gesellschaften und Organisationen durch präzise und ausgefeilte Planung auf vernünftige Weise gestalten und steuern könne. Planung galt als das probate Mittel, eine bessere Zukunft anzusteuern.

Allerdings wurde recht schnell klar, dass es sich dabei um eine unrealistische Vorstellung handelte, weil die Wirklichkeit regelmäßig sehr anders eintrat als während der Planung vermutet und beabsichtigt. Seither hat es 
vielfältige Weiterentwicklungen des Governance-Begriffes gegeben, die sich in einem normativ-speziellen und einem analytisch-allgemeinen Konzept zusammenfassen lassen (vgl. hierzu im Detail Langer/Hüther 2009).

Als normativ-spezielles Konzept bezeichnet Governance sozusagen die "Lehre vom guten Regieren und Wirtschaften", die eine bestimmte Form der Regulierung und Gestaltung politischer, sozialer und ökonomischer Systeme sicherstellen soll.

Meistens ist dies in Abgrenzung zu herkömmlichen, weniger "guten", weniger zielorientierten oder weniger demokratischen Formen gedacht: Wo Weisung durch einen "Steuermann" herrschte, sollte mehr Selbstverantwortung und Beteiligung der vormals Gesteuerten sein; wo Hierarchie war, sollten Netzwerke entstehen; wo der enge Blick auf formale Strukturen der Aufbau- und Ablauforganisation waltete, soll eine weitere, offene Perspektive auf die zahlreichen Stellgrößen in ihrem komplexen Zusammenspiel eingenommen werden. Beispiele für derartige normative Konzepte sind "good, global und corporate governance".

Ein klassisches Beispiel dafür liefert Rosenau, wenn er den "Governance“Begriff strikt von "Government" unterscheidet und neben der Existenz formeller Regelsysteme bei diesem Begriff auf die unbedingte Notwendigkeit von intersubjektiv geteilten Bedeutungen verweist, während Government auch ohne diese auskomme und selbst gegen starke Opposition wirksam werden könne.

"[...] governance is not synonymous with government. Both refer to purposive behavior, to goal-oriented activities, to systems of rule; but government suggest activities that are backed by formal authority, by police powers to insure the implementation of duly constituted policies, whereas governance refers to activities backed by shared goals that may or may not derive from legal and formally prescribed responsibilities and that do not necessarily rely on police powers to overcome defiance and attain compliance. Governance, in other words, is a more encompassing phenomenon than government. [...] Governance is thus a system of rule that is as dependent on intersubjective meanings as on formally sanctioned constitutions and charters" (Rosenau 1992, S. 4). 
Entscheidet man sich hingegen für den analytischen Governance-Begriff, wie wir es in unserem Projekt für die DFG getan haben, so erlaubt diese Governance-Perspektive, deren Bedeutung ich damit implizit erkläre, gewissermaßen einen Blick aus der Vogelperspektive auf wechselseitige Steuerungs-, Beeinflussungs- und Regelungsversuche verschiedenster Akteure und auf die Interdependenzbeziehungen, die sich daraus ergeben. Sie wird damit den komplexen, grenzüberschreitenden Verflechtungen der Akteure in institutionellen Regelsystemen besser gerecht und kann auch realistischer nach Bedingungen des Interdependenzmanagements forschen. Externe und Selbst-Steuerungspotenziale können damit gleichzeitig erfasst werden. Dies ermöglicht es, ein differenzierteres und realistischeres Bild der Regulierung sozialer Einheiten, wie zum Beispiel einer Universität oder einer Fakultät, zu gewinnen.

3 Die Universität in der organisationssoziologischen Deutung

Analysen über Universitäten lauteten bis vor gar nicht langer Zeit noch etwa wie folgt:

- Bei Universitäten handelt es sich um Organisationen auf Basis „organisierter Anarchien“, in anderen Umschreibungen auch „organisierter Inkompetenz" oder "organisierter Unverantwortlichkeit". Diese eindrucksvolle Analyse universitärer Entscheidungsprozesse verdanken wir Cohen/March/Olsen (1972) mit ihrem Garbage Can-Model of Organizational Choice, das sich in Erweiterung der verhaltenswissenschaftlichen Entscheidungstheorie auf Phänomene von "Mehrdeutigkeit", „Unklarheit" oder „ambiguity“ stützt. Solche „mehrdeutigen" Situationen sind nach Ansicht von Cohen/March/Olsen nicht nur, aber vor allem in Organisationen wie zum Beispiel Universitäten die Regel (vgl. hierzu im Detail v. Lüde 2003).

- Universitäten sind festgefahrene Gemischtwarenläden, deren kulturelle Heterogenität Wandel verhindert (Schimank 2001). Dies wurde als erfolgreiches Scheitern apostrophiert.

- Universitäten sind institutionelle Organisationen, die sich strukturell äußeren Umwelten anpassen können, auf der Handlungsebene jedoch 
weiterhin ihrer eigenen Logik folgen. Bei diesem Phänomen handelt es sich um die Entkopplung der Ebene der formalen Struktur von der Ebene der Akteure (Meyer/Rowan 1977 sowie später mit hiervon abweichender Sichtweise DiMaggio/Powell 1983).

- Bei der Organisation von Universitäten handelt es sich um machtvolle Spiele, in denen die Organisationsmitglieder nach dem Erhalt von Ungewissheitszonen streben (Crozier/Friedberg 1993; zu einer Übersicht und Re-Analyse vgl. Köhler/v. Lüde et. al. 2003).

- Universitäten kommunizieren bloß den Wandel, sie handeln aber nicht so Brunsson (1989), wenn er von talk statt action spricht. Dies hängt einerseits mit einer Vielzahl inkonsistenter Ansprüche, die die Gesellschaft an eine Universität stellt, zusammen. Zum anderen werden Reformen nicht durchgeführt, um tatsächlich Verbesserungen der Organisation zu erreichen, sondern lediglich zur Erzeugung von Stabilität einer Organisation.

- Bei Universitäten handelt es sich um eine fragmentierte Institution isolierter Individualisten, so Langer (2006) in der wohl umfassendsten empirischen Analyse universitärer Entscheidungsprozesse an deutschen Universitäten. Ähnlich argumentieren Hanft (2000) und Müller-Böling (2000), wenn sie davon sprechen, dass jede Sub-Einheit der Universität mit relativ großen Spielräumen für inhaltliche Gestaltung ihrer Forschungs- und Lehreinheit ausgestattet ist, die häufig aber von den Gesamtinteressen der Universität abweichen.

4 Auf dem Weg zu einem neuen Governance-Regime

All diese Beschreibungen, die leicht erweiterbar wären, laufen auf den gleichen Sachverhalt hinaus: Universitäten wurde eine innere Reformunfähigkeit bescheinigt, auch wenn dies kein Alleinstellungsmerkmal von Universitäten ist (vgl. zum Beispiel bezogen auf die Organisation von Schulen v. Lüde 2007). Vor diesem Hintergrund wurde in den letzten Jahren in Deutschland eine Vielzahl von Reformen im Universitätsbereich angestoßen - oder besser: den Universitäten verordnet und aufgezwungen. 
Diese betreffen

- personalrechtliche Bereiche (Tarifvertrag für den öffentlichen Dienst der Länder [TVL] statt Bundesangestelltentarif [BAT], Juniorprofessur, Umstellung auf leistungsbezogene Besoldung der Professoren),

- budgetäre Bereiche (Umstellung der Finanzierung auf Globalbudgets, Übergang von der Kameralistik zur Doppik, Einführung von Studiengebühren),

- aber auch formal strukturelle Bereiche (Stärkung der Position des Präsidenten und der Dekane, Schaffung von externen Aufsichts- und Steuerungsorganen wie zum Beispiel den Hochschulräten, Schwächung der Mitbestimmungsgremien).

Einen immer bedeutenderen Stellenwert nehmen auch unterschiedliche Systeme der Leistungsbewertungen in Lehre und Forschung ein, und zwar sowohl innerhalb einer Universität oder Fakultät als auch vergleichend im nationalen Maßstab. Prominentes Beispiel ist das Forschungsrating mit den beiden exemplarisch untersuchten Fachgebieten Chemie und Soziologie, die als Pilotstudien des Wissenschaftsrates angelegt waren und deren Ergebnisse am 18. Dezember 2007 beziehungsweise am 18. April 2008 veröffentlicht wurden (Wissenschaftsrat 2008). Dabei war die WiSo-Fakultät bei der Pilotstudie zur Soziologie mit erheblichem Erhebungsaufwand selbst beteiligt und hat in der Bewertung gut bis sehr gut abgeschnitten. Die reine Hochschulgovernance erweitert sich mit der Bewertung von Forschungsleistungen zu einer Governance der Wissenschaften.

Hinzu kommt die Vereinheitlichung der Studienabschlüsse im europäischen Raum im Rahmen des Bologna-Prozesses, mit der gleichzeitig die Lehre an den Universitäten umfassend restrukturiert wird. Die Reformbemühungen umfassen eine Vielzahl von Anwendungsfeldern und versuchen, damit grundlegend in die Strukturen der Universität einzugreifen. Dies geschieht gleichzeitig, wenig koordiniert und mit zum Teil nicht kompatiblen Zielsetzungen, wie zum Beispiel die Erhöhung der Lehrverpflichtung bei gleichzeitiger Erwartung erhöhter wissenschaftlicher Exzellenz in der Forschung, wobei diese Ziele noch stärker als bisher in Konkurrenz zu einander geraten.

Als tiefer liegenden Grund für ähnlich auch international vorzufindende Reformbestrebungen an Universitäten wird generell eine Neubewertung staatlicher Aufgaben und öffentlich-rechtlicher Organisationen gesehen 
(Braun/Merrien 1999). Deutlichstes Kennzeichen hierfür ist das sogenannte "New Public Management" (NPM), das sich seit Anfang der 80er-Jahre auf der Ebene des Reformdiskurses dominant positionieren konnte. Ein wichtiger Baustein dieses Konzeptes ist die Übertragung von Governance-Mechanismen und Managementmethoden der Privatwirtschaft auf den öffentlichen Sektor.

Auch deutsche Universitäten unterliegen, allerdings im internationalen Vergleich „verspätet", diesem Prozess der Ökonomisierung. In der Literatur wird mit einigen Interpretationsunterschieden im Detail ziemlich einheitlich davon ausgegangen, dass das deutsche Universitäts- und Wissenschaftssystem sich derzeit von einem Selbstverwaltungsmodell in Richtung eines Managementmodells bewegt (zum Beispiel de Boer et al. 2007; Jansen 2007; Schimank 2005). Gekennzeichnet ist das Managementmodell durch höhere Konkurrenz, eine Stärkung der internen Hierarchie innerhalb der Universitäten, einer Schwächung des Kollegialitätsprinzips und einer verstärkten Außensteuerung gegenüber einer Detailsteuerung durch die Politik. Zielsetzung dieser Veränderungen ist neben einer Performanzverbesserung in Forschung und Lehre auch die Steigerung der internen Entscheidungseffizienz an den Hochschulen.

Umgesetzt werden die Universitätsreformen in Deutschland insbesondere durch veränderte Bestimmungen in den Landeshochschulgesetzen der Bundesländer. Vermittelt über die Organisation Universität wirken diese auf die Handlungskontexte der Wissenschaftler in Lehre und Forschung. Aufgrund des föderalen Universitätssystems in Deutschland unterscheiden sich die Regelungen der Landeshochschulgesetze zum Teil jedoch erheblich. Diese unterschiedlichen gesetzlichen Regelungen, zum Beispiel den Grad der Hochschulautonomie und die innere Struktur der Organisation betreffend, bilden damit das wichtigste zu beachtende Institutionenset, wenn man über Governance-Regime an deutsche Hochschulen forscht. So zeigt ein Spin-off aus dem anfangs erwähnten DFG-Projekt in Form einer fast fertiggestellten Dissertation von Otto Hüther, die die jeweiligen Hochschulgesetze zum Gegenstand hat, dass es unter den heterogenen gesetzlichen Rahmenbedingungen der Bundesländer in Deutschland nicht mehr gerechtfertigt ist, von der deutschen Universität zu sprechen (vgl. zu ersten Ergebnissen Hüther 2008).

Geht man von einem in den Sozialwissenschaften zentralen Ansatz zur Erforschung von Steuerungshandeln, dem akteurszentrierten Institutiona- 
lismus aus, sind jedoch gerade die gesetzlichen Regelungen für die (kollektiven) Akteure in den Universitäten als eine wichtige Variable zur Erklärung des Handelns und Entscheidens anzusehen. Die gesetzlichen Regelungen, verstanden als Institutionen, bilden quasi einen Rahmen, in dem Akteure handeln, ihre spezifischen Handlungsorientierungen bilden, die Handlungssituation wahrnehmen und dadurch eine spezifische Akteurskonstellation entstehen lassen. Allerdings wirken die gesetzlichen Regelungen aber keinesfalls handlungsdeterminierend. Dies ist darin begründet, dass Regelungen auch nicht eingehalten werden können, Machtverhältnisse illegitim genutzt oder aber formale Regelungen durch informelle Interaktionen ausgehebelt werden. Hiervon können auch formale Handlungsabläufe betroffen sein, etwa dann, wenn die durch den Gesetzgeber geschaffenen Freiräume für reduzierte bürokratischer Verfahrensabläufe, wie zum Beispiel bei der möglichen Beschleunigung von Berufungsverfahren, durch neue restriktive interne Verfahren kompensiert werden. Darüber hinaus begrenzt die Unfähigkeit, die Kontrolle über Ressourcen vollständig institutionell sicherzustellen, den beabsichtigten Regelmechanismus. (Mayntz/ Scharpf 1995, S. 49)

Weite Teile der wissenschaftlichen Literatur gehen jedoch nach wie vor von einem homogenen deutschen Universitätssystem und von einer problemlosen Umsetzung allgemeiner Zielvorstellungen in ein konkretes, den gesetzlichen Vorgaben folgendem Regelwerk aus, wobei die tatsächliche Umsetzung dieser Ziele wenig beachtet wird. An einer solchen problemlosen Umsetzung kann, besser muss, aber gezweifelt werden. Wird den Landesregierungen unterstellt, dass sie mit den Hochschulreformen zumindest eine ähnlich gelagerte Zielorientierung verfolgen, sprechen die differenzierten gesetzlichen Regelungen gerade gegen die Annahme einer einfachen Umsetzung. Auch in der Politik ist der Unterschied zwischen talk - verwiesen sei nur auf die vielen Hochglanzbroschüren zu den Universitätsreformen der Bundesländer - und action, gemeint sind die Regelungen der Landeshochschulgesetze, in den Blick der Analyse zu nehmen.

Es wäre leicht möglich, diesen kritischen Blick auf gesetzliche Regelwerke und ihre tatsächliche Umsetzung im Hochschulsystem sowie deren intendierte und nicht intendierte Folgen noch weiterzuführen. Spannend sind nun die kommenden Analysen und Folgerungen unserer auswärtigen Experten. Deswegen will ich abschließend auf die bereits erwähnten Beobachtungen Niklas Luhmanns noch einmal zurückkommen, wonach es sich 
bei Organisationen um unberechenbare Systeme handelt - auch wenn manchen dieser gleichzeitige Verweis auf den akteurszentrierten Institutionalismus und die Systemtheorie zu weit gehen mag.

Wenn ich zurückblicke auf die Anfangsjahre dieser WiSo-Fakultät, dann wäre es eine hoch riskante Angelegenheit gewesen, darauf zu wetten, dass am Ende dieser drei Gründungsjahre eine Satzung im Fakultätsrat einstimmig - wie tatsächlich geschehen - verabschiedet und damit die Gründungsphase beendet wird. Wir sehen ja derzeit am Beispiel der Krise im Finanzsystem, wohin hoch riskante Wetten auch führen können.

Lassen Sie mich vor dem Hintergrund dieser mit vielen Unsicherheiten belasteten Ausgangssituation der WiSo-Fakultät und der gleichwohl erreichten neuen Organisationsstruktur uns allen eine Empfehlung mit auf den Weg geben, die ebenfalls von Luhmann stammt und die Eigenlogik einer von ihm gedachten Organisation umschreibt: Es komme darauf an, „Organisationen mit einem Selbstverständnis auszustatten, das es ihnen ermöglicht, ihre eigene Sache selbst zu verantworten“. Das Gründungsdekanat hat, wenn Sie sich zum Beispiel an die Debatten um die Gründung der Graduate School erinnern, zumindest implizit immer die Orientierung an dieser Maxime gesucht, wenn es versucht hat, hier einen Identifikationskern der neuen Fakultät für alle Departments/Fachbereiche und Studiengänge herzustellen. Ich wünsche der WiSo-Fakultät, dem amtierenden und dem neuen Dekanat, dass ihnen das auch in anderen Akteurskonstellationen gelingen möge.

\section{Literatur}

Braun, Dietmar; Merrien, François-Xavier (1999): Governance of Universities and Modernisation of the State: Analytical aspects. In: Braun, Dietmar; Merrien, François-Xavier (Hg.): Towards a New Model of Governance for Universities. A comparative view. London, S. 9-33.

Brunsson, Nils (1989): The Organization of Hypocrisy. Talk, Decisions, and Actions in Organizations. Chichester.

Cohen, M. D.; March, J. G.; Olsen, J. P. (1972): A Garbage Can Model of Organizational Choice. In: Administrative Science Quarterly 17/1972, S. 1-25.

Crozier, Michel; Friedberg, Erhard (1993): Macht und Organisation: Die Zwänge kollektiven Handelns. Frankfurt am Main. 
De Boer, Harry; Enders, Jürgen; Leisyte, Liudvika (2007): Public Sector Reform in Dutch Higher Education: The Organizational Transformation of the University. In: Public Administration, Jg. 85, H. 1, S. 27-46.

DiMaggio, Paul J.; Powell, Walter W. (1983): The Iron Cage Revisited: Institutional Isomorphism and Collective Rationality in Organizational Fields. American Sociological Review, Vol. 48, No. 2., S. 147-160.

Hanft, Anke (2000): Sind Hochschulen reform(un)fähig? Eine organisationstheoretische Analyse. In: Hanft, Anke (Hg.): Hochschulen managen. Zur Reformierbarkeit der Hochschulen nach Managementprinzipien. Kriftel, S. 3-24.

Hüther, Otto (2008): Starke Dekane - schwache Professoren? Vergleich und Analyse der deutschen Landeshochschulgesetze. In: Hochschulmanagement. Zeitschrift für die Leitung, Entwicklung und Selbstverwaltung von Hochschulen und Wissenschaftseinrichtungen, Jg. 3, H. 1, S. 23-27.

Jansen, Dorothea (Hg.) (2007): New Forms of Governance in Research Organizations. Disciplinary Approaches, Interfaces and Integration. Dordrecht.

Köhler, Michael; Lüde, Rolf v.; Rölke, Heiko; Spresny, Daniela (2003): Machtspiele strategischer Akteure. Ein mikropolitisches Organisationsmodell. In: Lüde, Rolf v.; Moldt, Daniel; Valk, Rüdiger (2003): Sozionik - Modellierung soziologischer Theorie. Münster - Hamburg - London.

Langer, Roman (2006): Hinter den Spiegeln universitärer Governance. Dynamiken informeller Selbstregulierung an der Universität. Unter Mitarbeit von Daniela Spresny. Berlin.

Langer, Roman; Otto Hüther (2009): Das Governance-Konzept. In: Lüde, Rolf v.; Moldt, Daniel; Valk, Rüdiger (Hg.) (2009): Selbstorganisation und Governance in künstlichen und sozialen Systemen. Abschlussbericht des DFG-Projektes „Emergenz in dynamischen Prozessen - Dirigismus und symbolische Politik" im Rahmen des DFG-Schwerpunktprogrammes "Sozionik“. Berlin.

Lüde, Rolf v. (2003): Jenseits von garbage cans? Kommunikation und Entscheidung in Universitäten. In: Hillmann, Karl-Heinz; Oesterdiekhoff, Georg W. (Hg.): Die Verbesserung des menschlichen Zusammenlebens. Eine Herausforderung für die Soziologie. Opladen, S. 263-287. 
Lüde, Rolf v. (2007): Den Wandel der Organisation Schule selbst gestalten: Grundfragen der Organisationsentwicklung. In: Pfundtner, Raimund (Hg.) (2007): Grundwissen Schulleitung. Handbuch für Schulmanagement. Köln, Neuwied.

Lüde, Rolf v.; Moldt, Daniel; Valk, Daniel (Hg.) (2009): Selbstorganisation und Governance in künstlichen und sozialen Systemen. Abschlussbericht des DFG-Projektes „Emergenz in dynamischen Prozessen - Dirigismus und symbolische Politik" im Rahmen des DFG-Schwerpunktprogrammes „Sozionik“. Berlin.

Luhmann, Niklas (2000): Organisation und Entscheidung. Opladen.

Mayntz, Renate; Scharpf, Fritz W. (Hg.) (1995): Gesellschaftliche Selbstregelung und politische Steuerung, Frankfurt am Main.

Meyer, John W.; Rowan, Brian (1977): Institutionalized Organizations: Formal Structure as Myth and Ceremony. In: The American Journal of Sociology, Jg. 83, H. 2, S. 340-363.

Müller-Böling, Detlef (2000): Die entfesselte Hochschule. Gütersloh.

Rosenau, James N. (1992): Governance, order, and change in world politics. In: Rosenau, James N.; Czempiel, Ernst-Otto (Hg.) (1992): Governance without government: Order and change in world politics. Cambridge.

Schimank, Uwe (2001): Festgefahrene Gemischtwarenläden - Die deutschen Hochschulen als erfolgreich scheiternde Organisationen. In: Stölting, Erhard; Schimank, Uwe (Hg.): Die Krise der Universitäten. Leviathan Sonderheft 20/2001. Wiesbaden, S. 223-242.

Schimank, Uwe (2005): „New Public Management" and the Academic Profession: Reflections on the German situation. In: Minerva, Jg. 43, S. 361376.

WiSoG (2005): Gesetz zur Bildung der Fakultät Wirtschafts- und Sozialwissenschaften der Universität Hamburg und zur Änderung des Hamburgischen Hochschulgesetzes (WiSoG) vom 8. Februar 2005. HmbGVBl. S. 28.

Wissenschaftsrat 2008: Forschungsrating, http://www.wissenschaftsrat.de/ pilot_start.htm. 

The central-decentral paradox

The university as a merging organisation

Hans E. Roosendaal and Kasia Zalewska-Kurek

1 Introduction

It was a pleasure to present this short paper at the Symposium 'Hochschulmanagement - neue Wege der Hochschulgovernance' on the occasion of the retirement of Prof. Dr. Dr. h. c. Wolfgang Weber from the University of Hamburg. The title and subject of this presentation was chosen at the specific request of Wolfgang Weber.

The central-decentral issue is indeed a paradox, although it is not always perceived as such by university management, which sometimes views the university as consisting of two disparate organisations: the organisation of the primary processes of research and teaching versus the organisation of the secondary or auxiliary processes, such as information provision, information and communication technology, administration or even management itself.

In this paper we will address this central-decentral issue by viewing the university as a permanently merging and integrating organisation, thereby making use of the existing strategic management literature on mergers, acquisitions, integration after a merger or an acquisition, reorganisations, etc. (Haspeslagh \& Jemison 1991).

At present, universities are developing from the Humboldtian form of university towards new forms of themselves, such as e.g. the entrepreneurial university introduced by Clark (2001). Whatever type of university is being aspired to, the main driving force is to gain more autonomy and to create a clear position of competitive advantage vis à vis other universities nationwide or even worldwide, with the overall goal to arrive at a heterogeneous landscape of universities. This development then requires a 
clear and articulated institutional strategy, as a corporation needs a corporate strategy. Indeed, the university can be seen as an institution or a sort of corporation with the faculties as divisions. A 'sort of' corporation, as not everything we know from corporate management is easily transferable to the university environment.

Such an institutional strategy will amongst other things comprise of a quality management strategy, as this is required for the accreditation of the university and its concomitant reputation that is so essential for a competitive advantage. This institutional strategy, and above all quality management, will result in new strategic positioning of the relevant actors both internal such as the positioning of the centre, i.e. the central management: the board or the presidency, the faculties and the different functions and services, be these line or staff, and external. Relevant functions are strategic functions such as strategic human resource management or financial strategy, while services can comprise of administration services or back office services supporting e.g. human resource management.

It is sometimes questioned whether a public organisation like a university can indeed develop an effective strategy, the argument to the contrary being that the environment being also a political environment is in tremendous flux. But if a strategy is being perceived as a flexible model to describe the environment from the viewpoint of the mission of an organisation such as a university, such a model or strategy is a necessity for the university to be able to position itself in this changing environment. It is as with the famous Gedankenexperiment of Sir Karl Popper when giving a student the assignment 'observe'. Either the student starts to list anything that there is to observe, which results in a never ending exercise or an indefinite regression, or the student replies with the question: 'what should I observe?', in this way asking for the model on which he is requested to describe the environment. A strategy functions as such a model and has as its primary task to describe the environment from the viewpoint of the mission, vision and goals of the organisation. It is precisely for this reason that a clear strategy is indispensable for any organisation, be this a private or a public one.

A most pertinent strategic issue for such an institutional strategy is the issue of central versus decentral organisation. This issue deals with the relation between centre and faculties or research institutions within the university, between primary and secondary processes, and determines to a large extent the management responsibilities and styles. The question is not 
a black or white question of having either a central or a decentral organisation as it is often perceived, and leading to an almost ideological debate of either central or decentral, but rather which shades of grey will comply with the balance in strategic positioning of the different stakeholders that is necessary to attain the institution's goals. A clear institutional strategy is then needed to formulate these goals and is required to deal effectively with the central-decentral paradox.

The central-decentral issue is always a hot topic in any organisation's strategy, be this a private or a public organisation. For a multi-division enterprise this issue is about the relation between centre and divisions; for a university it is primarily about the relation between centre and faculties. Managers of public organisations are sometimes of the opinion that the hierarchy in a commercial enterprise may lend itself to smoother solutions, but this only shows that these managers are not very familiar with management developments in commercial enterprises, and in particular in knowledge intensive organisations.

The rules of engagement are indeed very similar: both the centre and faculties (or divisions) have to prove their added value for the organisation as a whole. This results in a relation of mutual dependence or interdependence between these stakeholders with a clear quid pro quo while at the end of the day it is the institutional (or corporate) identity or reputation that is at stake. Like any competing organisation the university cannot allow itself bad apples, neither in the centre nor in a faculty.

\section{Integration in alliances, mergers and acquisitions}

As stated in the introduction, we will take the viewpoint of the university as a merging and integrating organisation. We do so as most universities are in a transition from a Humboldtian type of organisation with very independent faculties and a lean and mean management centre towards an organisation that needs to be more integrated as demanded amongst other reasons by the necessary strategic repositioning to gain competitive advantage. As we have noted above, centre and faculties are becoming more interdependent under this strategic redirection. This requires a reorganisation of the university in terms of a new strategic positioning of the stakeholders in 
the university, and this reorganisation is a sort of integration with the goal to create value in terms of autonomy, institutional identity and competitive advantage. This is just as in a merger or acquisition where it is not sufficient to bring the two organisations under one roof, but where the real value creation results from an effective and efficient integration of the two organisations.

Integration strategies aim at creating value by making optimal use of the synergies that exist between two organisations. This means that integration is a strategic process and as such is very suitable to restructure industries, enterprises or other organisations like a complex organisation as a university. In fact, quite a number of merger or acquisition failures can be traced back to poor integration even if the acquisition were strategically well justified (Haspeslagh \& Jemison 1991).

Following Haspleslagh \& Jemison we can look at integration making use of two dimensions of strategic positioning: organisational autonomy and strategic interdependence. Organisational autonomy is then defined as selfgoverning in deciding about the value proposition and market segment of the organisational entity - for brevity we will use the word entity in the remainder of this short paper. Value proposition can be the specific research and teaching of either at the entire university level or at the faculty level and market segment can be the part of the research or wider community the entity wants to serve. Strategic interdependence is defined as the sharing of heterogeneously distributed strategic resources. Heterogeneous resources can be research instrumentation, in particular expensive equipment, e.g. a clean room or an accelerator, but can likewise be e.g. access to information technology or research information. The main point to note in this context is that it is not the desire to be autonomous or independent as most organisations would want that, but it is the necessity to compromise on autonomy and to become interdependent to a certain degree in order to attain the entity's strategic goals. By looking at the strategic positioning using these two dimensions we combine the outside-in view, i.e. viewing the organisation influenced by the environment, with the inside-out view, i.e. viewing the organisation as leveraging the environment on the basis of its competencies and unique resources.

Combining these two dimensions leads to a continuum of modes of integration as shown in figure 1, also showing four ideal (ideal in the Weberian sense) modes of integration: the holding for the combination of low ne- 
cessities for both organisational autonomy and strategic interdependence, amalgamation or absorption for the combination of a low necessity for organisational autonomy with a high necessity for strategic interdependence, preservation for the combination of a high necessity for organisational autonomy with a low necessity for strategic interdependence, and finally symbiosis for the combination of both a high necessity for organisational autonomy and strategic interdependence. Each different type of integration requires a different management approach. These different management approaches will be discussed below, following Haspeslagh \& Jemison (1991).

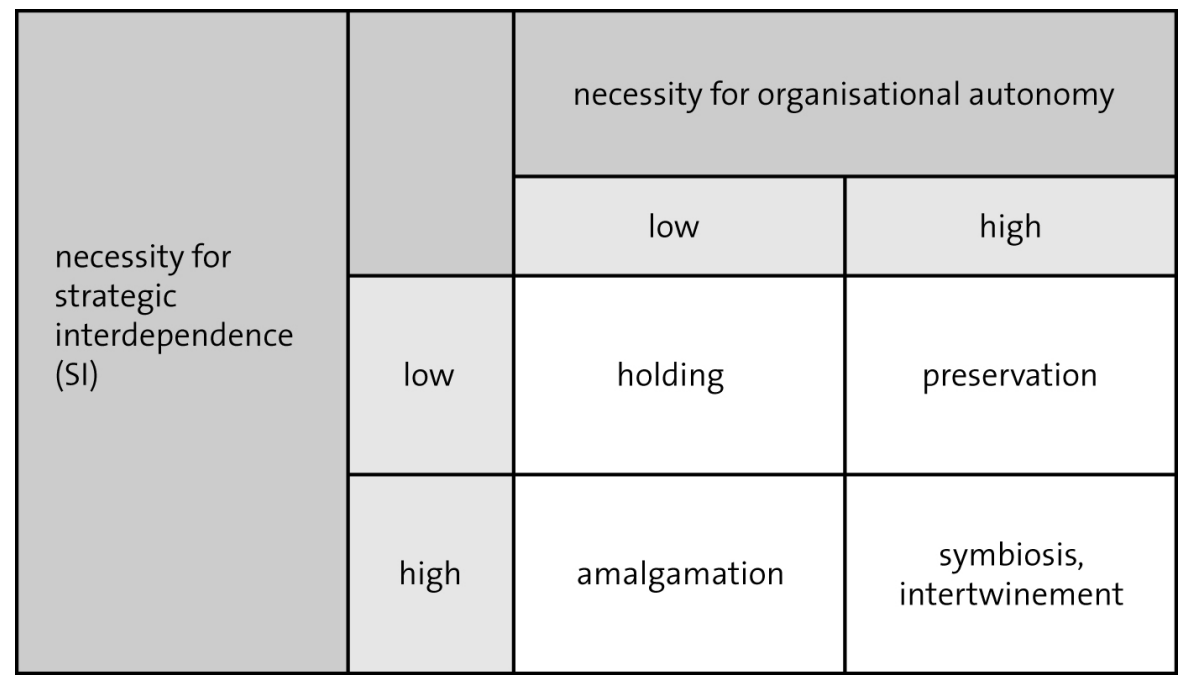

Figure 1: modes of integration

The holding is well known and represents an organisation in which the centre is generally very lean. Management control style can be characterised as financial control, the entities are autonomous and are primarily managed by financial objectives.

Amalgamation or absorption is the type of integration that is used for mergers or acquisitions aiming to strengthen the domain in which the organisation is active. Integration management is characterised as determined, meaning that right from the start there is a clear blueprint for the con- 
solidation of the new organisation, the new organisation is managed from the start as a whole, best practices from both sides are adopted and the original complementarity is strengthened. In terms of leadership there is a clear transfer of the affiliation. The original interface between the two organisations disappears quickly and this transition is smoothly managed. The added value being created is primarily in efficiency gains. Typical examples of mergers or acquisitions are e.g. mergers of airlines, supermarkets, electrical appliances companies, etc. Also, the acquisition of the German Democratic Republic by the Federal Republic of Germany was managed like an absorption, with all the consequences for the still existing divide between the two constituents. The management control style can more be characterised as strategic planning.

Preservation is aimed at domain exploration. The goal in such a merger or acquisition is clearly to learn and not to homogenise the two organisations. Thus the interface is being managed as gate keeping, keeping the two organisations separate except for well-controlled strategic interventions, and the unit is being supported in its original goals, meaning that the purpose is being confirmed both internally and externally, knowledge is being accumulated for learning purposes and the commitments of the unit are proactively defended. An example of such a preservation merger is e.g. the takeover of a nutrition company by an oil company in order to explore the bio industry, or the merger of two research institutes with the purpose of becoming involved in interdisciplinary research.

The most complex type of integration is the symbiosis. The aim here is domain expansion. Symbiotic integration starts as preservation followed by content and competence transfer. Both units are adjusted to each other, starting with operational transfers, gradually transforming into strategic transfers and leading to a long term amalgamation of the two units. This means that the purpose of both units is redefined. The interface between the two units is carefully managed, like regulating a membrane. Examples of such mergers or acquisitions are e.g. takeovers of databases by scientific publishers in making the transition to the digital era with its opportunities for integrated information products. In the latter two types, preservation and symbiosis, a strategic control style seems most appropriate as management control style.

It may be obvious that these modes of integration are ideal modes in the Weberian sense, implying that in real life a mixture of integration modes 
can be used by applying a different type of integration to specific functions or entities within the overall organisation. The overall integration is then predominantly characterised as a specific ideal type.

3 The university as a permanently merging and integrating organisation

After this brief excursion into strategic management issues from the area of mergers and acquisitions we will now return to the topic at hand: the university, and will inspect if we can apply some of the above to the university in its struggle to become an autonomous and competitive organisation with a clear strategic focus in terms of its primary processes of research and teaching.

The strategic positioning model has been successfully applied by Kurek et al. (2007) to study the strategic positioning of the researcher, as individual, as research group or as research institute in the environment, be this the research environment proper or the wider societal environment; combining in this way the inside-out view with the outside-in view. This was new, as policy studies describing mode 1 and mode 2 such as by Gibbons (1999) or Ziman (1994) restrict themselves to the outside-in view in describing the influence of the societal environment on research. Combining the inside-out view with the outside-in view is required to allow strategy development on the part of the researcher. Applying the mode 1 of strategic positioning, Kurek et al (2007) were able to derive different modes of positioning for the researcher: mode 1 or the ivory tower and mode 2 or the strategic researcher, both also known from policy studies ${ }^{*}$, as well as a new mode, mode 3: the research entrepreneur. And it is the research entrepreneur who is leveraging the environment by creating demand for his research products rather than supplying on the demand of the environment. Having applied this strategic positioning model to research and its positioning in the environment, we make in this paper an attempt to apply the model to the university, analysing the strategic positioning of its different entities.

\footnotetext{
* However, by restricting to the outside-in view only mode 1 and mode 2 from these policy studies are different from the mode 1 and mode 2 from Kurek et al. Rather, the former modes are encapsulated in the latter modes.
} 
Inspecting the modes of integration in figure 1, we are tempted to compare the Humboldtian university with the holding type. The centre is very lean, the rector being the primus inter pares of the faculty deans, and the terms of office of all managerial functions are extremely short, reducing in this way their managerial influence, in particular with respect to long term strategy. The rector and deans are elected for one or at most two years. In Germany the chancellor as head of the administration has a powerful position, being also in command of the budget and as liaison officer to the powerful ministry.

As we have seen above, the transition to a more autonomous and competitive organisation with a clear strategic focus requires a realignment or integration of the structures of the university, and in particular of the management structures. As we remarked above different integration strategies may be applicable for different integrations. This can also be the case in a university where different integration strategies may be needed for the integration of different entities, such as faculties, administration or line or staff departments. Figure 2 visualises the different alignment or integration paths that a university can take in departing from the Humboldtian structure.

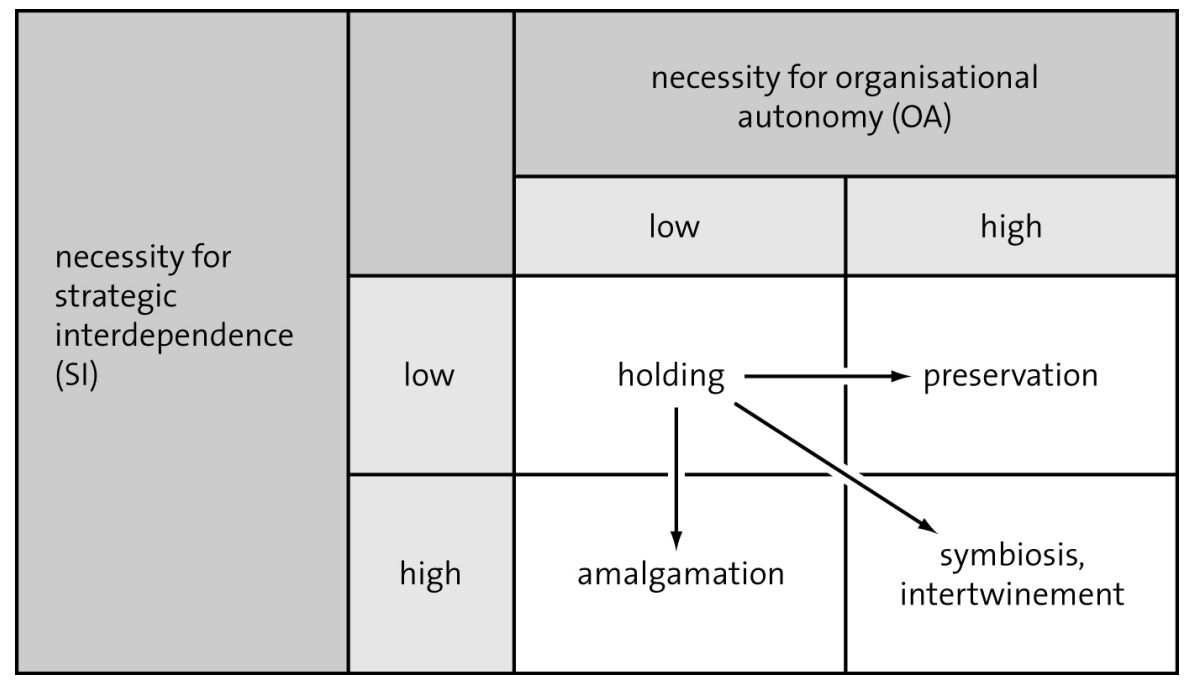

Figure 2: integration paths 
Depending on the mission, vision and strategic goals of the university as laid down in the institutional strategy, each university has to choose how to align the faculties and different departments as to create a clear institutional identity commensurate with the resources and competencies in research and teaching in which this university excels. There is clearly not one recipe that fits all universities. In particular, the inside-out element present in the model demands that each university creates an organisation fitting its unique resources and competencies and by doing so will distinguish itself from other universities, thereby creating a clear competitive advantage.

\subsection{Primary processes}

In this short paper, like in the presentation, we will restrict ourselves to giving just some examples as illustrations. An illustration could be to look at the organisation of the primary processes of research and teaching, each having their own different responsibilities, funding and cash flows and consequently their own accounting lines within the organisation. This calls for a managerial separation, albeit not for a separation in content. In particular at the master level a tight content relation between research and teaching is mandatory. One way to organise this managerial separation is to separate at the top, i.e. at the board or presidency level, in creating research institutes as separate from teaching schools. It may be remarked that in this way there need not be a one to one mapping between research institutes and teaching schools.

Starting from the fragmented research focuses now present at the university, this scheme allows for integration towards a limited number of new research focuses, possibly of an interdisciplinary or multidisciplinary nature if so desired, properly supported by a solid disciplinary basis. A condition is that researchers should to a certain extent be autonomous in setting research goals and directions within these research focuses.

This calls for an integration path starting with preservation and gradually moving into symbiosis.

In teaching and learning one could apply a somewhat different strategy. With respect to disciplinary bachelors, a preservation strategy seems the obvious choice; however for a broad bachelor spanning a number of disciplines a symbiosis strategy is more appealing. For masters, as they are strong- 
ly related to the research strongholds of the university, a symbiosis strategy seems the appropriate choice.

\subsection{Secondary processes}

With respect to the secondary processes, an option is to distinguish between line functions and staff services. Line functions could either be located centrally or decentrally, depending on the location of the portfolio holder. The location of the portfolio holder may be determined as the location of the budget owner, being either the centre for university wide functions, such as strategic human resource management or strategic financial management, or as the location of a faculty, institute or school in case of again human resource or financial management, but now specific in terms of the chosen autonomy of this entity. This results in high necessities for both autonomy and at the same time interdependence and thus calls for a more symbiotic approach.

General supporting and adaptable functions, such as administration, personnel or financial or other types of administration need not be duplicated within the university and could therefore comfortably be organised in the centre, however with proper outsourcing arrangements with the decentral entities. In general, this would call for an amalgamation strategy.

\subsection{University management}

With respect to the management of the university we have observed complementary roles for the centre on the one hand, and the faculties, institutes and schools on the other. Budget responsibilities and authorities will be spread over these different stakeholders and will be the object of negotiation between these stakeholders. Decentral entities such as faculties, institutes and schools and strategic functions will need to have clear powers of directives commensurate with their strategic position in terms of autonomy and interdependence. This calls for a symbiotic relation between these stakeholders following the principle of a clear allocation of management portfolios. This means that the sharing of responsibilities between the centre and these other stakeholders as we know them from the Humboldtian university need be adjusted, the purpose of leadership needs redefin- 
ing and the interfaces between these stakeholders should resemble flexible membranes rather than rigid iron curtains.

A number of aspects will play a role in this symbiotic relation between the centre and the other stakeholders. In deciding on its structure, the university should be led by the condition that this structure should allow the achievement of the university's strategic goals. If the university e.g. decides to have a strong centre, i.e. a more central structure, this centre has the task to decide on strategic decisions, actions, etc. and on how to position the entities within the university. Independent of the university's structure, university management should set a clear institutional strategy comprising a clear mission, vision and goals to communicate in order to be productive and competitive to all inside and outside stakeholders.

As stated above, university management requires the definition of stakeholders and issues to be addressed by them. This means that there must be a clear agreement and understanding of the relations to be established between the entities, and in alignment with the institutional strategy the activities to be performed by which entities. Management then involves establishing who will make which decisions, what will be the respective responsibilities, and which type of managerial control is most suitable for the organisation at hand.

In terms of a more concrete operationalisation we can envisage that the following aspects may be relevant for the relation between centre and faculties or research institutes: institutional strategy, acquisition of financial resources, investments, and budget. Within the faculties specifically an issue is the teaching programmes, capacities and teaching performance control. For the research institutes the following issues come to the fore: research programmes, funding and research performance control. On a lower level, in the relation between research directors and research groups issues can be research funding, research performance control and reporting lines. It should be understood that these examples cannot be exhaustive.

The overall administration apparatus supporting all these primary processes and comprising of routine management services could well be amalgamated at the centre, so as to provide an overall view and to avoid unnecessary duplication and costs, again with concomitant outsourcing arrangements with the decentral stakeholders. 
As we stated, different universities will have different structural configurations. The main condition is that the chosen configuration is in line with the specific institutional strategy of the university.

\section{Concluding remarks}

This short paper has been given at the Symposium 'Hochschulmanagement neue Wege der Hochschulgovernance' on the occasion of the retirement of Prof. Dr. Dr. h. c. Wolfgang Weber from the University of Hamburg. As stated in the introduction, the subject of the central-decentral paradox in university management was chosen at the specific request of Wolfgang Weber as this paradox is an issue that university managers are struggling with.

In this paper we have analysed management structures taken from the strategic management literature to see if solutions to the paradox might present themselves. The university is then seen as a continuously changing organisation, the starting point being a Humboldtian type structure. As the Humboldtian structure is a rather fragmented one, this then leads to the perspective of viewing the university as a continuously or permanently merging or integrating organisation. It therefore seems appropriate to look at the options strategic management knowledge on alliances, mergers and acquisitions can offer. This knowledge has already successfully been applied to analyse the strategic positioning of the researcher at various aggregation levels in the environment, narrow or broad. And indeed, if applied to the different entities of a university it allows and advises a number of different integration options, each requiring its own management approach and style.

The central-decentral divide or rather paradox has been seen to be a strategic issue in all organisations, be these public or private. It is and will remain a hot topic in strategic management and above all in university management. As the environment of the university changes, and it will continue to change, universities have to develop new strategies requiring in turn new central-decentral arrangements and integration strategies. The need to discern these changes and the knowledge of how to deal with them requires a clear and crisp institutional strategy on the part of the autonomous and highly competitive university, as a model to observe the environ- 
ment and as guidance to arrive at a consistent allocation of central and decentral managerial responsibilities.

The strategic positioning model presented in this short paper provides an analytical instrument for a transparent strategic discussion between the stakeholders. The model needs to be operationalised for an individual organisation to allow the specific inside-out view for this particular university. In this sense, strategic management knowledge on alliances, mergers and acquisitions as expressed in the strategic positioning model can be helpful for university management.

\section{Acknowledgements}

Hans Roosendaal would like to thank Wolfgang Weber for giving him the opportunity to give this presentation at the above mentioned workshop and for having seduced the authors into writing out this presentation as given on October 16, 2008 in Hamburg.

The authors should like to thank their co-author Peter Geurts of Kurek et al. (2007) for his contribution to the development of the strategic positioning model used here in a new application.

\section{References}

Clark B. (2001): The entrepreneurial university: new foundations for collegiality, autonomy, and achievement. Higher Education Management, 13 (2), pp. 9-24.

Haspeslagh P. C., and D. B. Jemison (1991): Managing acquisitions. Creating value through corporate renewal. New York.

Gibbons M. (1999): Science's new social contract with society. Nature 402, pp. C81-C84.

Kurek K., P. A. T. M. Geurts, and H. E. Roosendaal (2007): The research entrepreneur. Strategic positioning of the researcher in the societal environment. Science \& Public Policy 34 (7), DOI: 10.3152/030234207X244810.

Ziman J. (1994): Prometheus bound. Science in a dynamic steady state. Cambridge. 

Steuerung autonomer Universitäten: Erfahrungen

mit der österreichischen Universitätsreform

Barbara Sporn

1 Einleitung

Universitäten in Europa sind einem ständigen Wandel unterworfen. Vor allem die Autonomie der Hochschulen war in den letzten beiden Jahrzehnten ein vieldiskutiertes und oft umgesetztes Thema. In Systemen, die über öffentliche Finanzierung und dementsprechend bürokratische Steuerung verfügen, stellen autonome Universitäten eine besondere Herausforderung dar. Sie müssen effizient und effektiv geführt werden, gleichzeitig aber nicht gänzlich der staatlichen Kontrolle entweichen. Neue Steuerungsmodelle waren und sind gefragt. Dieser Beitrag unternimmt daher den Versuch, die Steuerung autonomer Universitäten anhand der österreichischen Praxis darzustellen.

\subsection{Steuerungsansätze für Universitäten}

Die Steuerung komplexer Systeme wie Universitäten hat die Forschung schon seit längerer Zeit beschäftigt (Cohen and March 1974; Mintzberg 1979; Baldridge 1983; Clark 1983; Birnbaum 1989). Dabei kamen vor allem Disziplinen wie die Betriebswirtschaftslehre, Organisationssoziologie, Volkswirtschaftslehre und Politikwissenschaft zum Tragen. Aus diesen Bereichen haben sich unterschiedliche Erklärungsmuster und Lösungsansätze herauskristallisiert, die hier im Überblick dargestellt werden. Eine gewisse chronologische Verbindung lässt sich ebenfalls feststellen. Am Anfang stand das bürokratische Regelwerk beziehungsweise das akademische Wertegefüge als Steuerinstrument. Durch die Einführung des Wettbewerbsgedankens kam es zu einer gesteigerten Marktorientierung. Das Kontraktmanagement und letztendlich die Ex-post-Steuerung stellen die am weitest verbreiteten Praktiken dar. 


\section{Steuerung über Werte und Normen}

Universitäten sind von ihrem Ursprung her Gelehrtengemeinschaften. Diese Konstellation hat es bedingt, dass die Steuerung vor allem über Werte und Normen der akademischen Gemeinschaft passiert. Professor/inn/en und Studierende agieren auf Basis eines Ehrenkodex miteinander. Das Lernen und Lehren stand im Vordergrund. Universitäten hatten generell die Aufgabe, Wissen zu generieren (durch Forschung) und dieses zu vermitteln (durch Lehre), um Studierende zu Bildungsbürger/innen zu machen. Das Wissen war breit angelegt und diente einem intellektuellen Streben und weniger der Erzielung eines besonderen Gewinns am Arbeitsmarkt. Ausbildung und Beruf standen nicht im Vordergrund.

Die Steuerung basierte auf einem verhaltensorientierten Ansatz. Besondere Werte und Normen zur Wissensgenerierung und -vermittlung standen im Vordergrund. Die Gemeinschaft der Lehrenden und Lernenden sollte sich an diese halten und so ihre Interaktion beziehungsweise Arbeitsweise maßgeblich prägen. Dieses Modell war vor allem in autonomen Universitäten des letzten Jahrhunderts stark präsent. Ihr Umfeld war durch relativ stabile Ressourcenlage, wenig staatliche Intervention und starke interne Einheiten geprägt. Wettbewerb und Knappheit gehörten nicht zu den Herausforderungen.

\section{Steuerung über Regeln und Gesetze}

Im Laufe der Zeit haben Universitäten immer mehr als Ausbildungsstätten an Bedeutung gewonnen und wurden zusehends öffentlich erhalten und finanziert. Der Staat hat sein Bekenntnis zur Erhaltung der Universitäten mit der Verpflichtung gekoppelt, über Regeln, Gesetze und Vorgaben die Steuerung der Hochschulen zu übernehmen. Dadurch ist eine Expert/inn/enbürokratie entstanden, die vor allem durch Gesetze gesteuert wurde. Die Eigentümer waren gut vertreten und konnten so Einfluss auf das Geschehen an Universitäten ausüben. Pflichterfüllung stand eher im Vordergrund. Strategien wurden von den offiziellen Behörden definiert. Die Professor/inn/en waren daran interessiert, ihre Position zu erhalten und in ihrer Disziplin zu reüssieren. Wenig strategische Planung konnte in diesem stark reglementierten Umfeld entstehen. 
Die Verrechtlichung der Steuerung von Universitäten hat die Rolle der öffentlichen Hand als Eigentümer abgesichert. Das hat dazu beigetragen, dass in vielen - vor allem kontinentaleuropäischen - Ländern die gesetzlichen Regelungen sehr weitreichend sind. Es werden die Erstellung von Curricula, die Anstellung von wissenschaftlichem Personal, die Bewirtschaftung der Gebäude oder das Berichtswesen gesetzlich geregelt. Damit wird natürlich auch der Handlungsspielraum der Universitäten und Hochschulen massiv eingeschränkt. Für die staatlichen Behörden musste eine große und kompetente Beamt/inn/enschaft aufgebaut werden, um die Administration zu steuern. Augenscheinlich hat das nicht oder nur wenig zur Effizienzorientierung beigetragen, da die jeweiligen Leitungsorgane der Universitäten mehr an der Regelerfüllung als an der Weiterentwicklung und der Förderung des unternehmerischen Denkens interessiert waren.

\section{Steuerung über den Markt}

Mit Ende der 1980er-Jahre begann der Staat seine Steuerungsmechanismen zu ändern (Höllinger/Steinbacher 1992; Titscher/Höllinger 2004). Teilweise war das durch die Budgetengpässe motiviert. Aber auch die Motivation, Studien marktgerechter zu gestalten, Entscheidungen schneller und effektiver zu treffen und Universitäten am Markt zu positionieren, trugen maßgeblich zur Änderung bei. Marktmechanismen wurden zur Steuerung eingesetzt. Das Spiel von Angebot und Nachfrage sollte die Dynamisierung der Universitätslandschaft begünstigen.

Die Wettbewerbsorientierung hat den Gedanken der Knappheit der Güter, des Vergleichs und des Benchmarkings mit sich gebracht. Universitäten mussten lernen, sich dem Wettbewerb zu stellen. Das bedeutete, ein Profil und einen strategischen Fokus aufzubauen, institutionelle Stärken zu definieren und entsprechende Maßnahmen zu entwickeln. Die Leistungsmessung rückte als Steuerungselement in den Vordergrund. Rankings, Evaluationen oder Benchmarking wurden als Instrumente eingesetzt. Ziel des Wettbewerbs sollte es sein, von außen erkennbar zu machen, welche Qualität an welcher Institution geboten wird.

Gerade die Profilbildung spielt in diesem Zusammenhang eine bedeutende Rolle. Der Wettbewerb bedingt nämlich, dass sich Universitäten und Hochschulen ein bestimmtes Profil oder einen Charakter geben, an dem sie erkennbar sind und an dem sich die internen Verteilungsprozesse orientie- 
ren können. Gerade Schlagworte wie „Stärken stärken“ oder „strategische Planung" haben Einzug in den Managementalltag an Universitäten gefunden. Die Universitäten gewannen Autonomie und mussten sich selbst ein Profil geben. Der Staat hat viel an Steuerungseinfluss aufgegeben.

\section{Steuerung über Ziele}

Hochschulen und Zielvereinbarungen sind ein relativ neues Phänomen (Fedrowitz, Krasny et al. 1999). Sie finden weite Verbreitung im deutschsprachigen Raum oder in Skandinavien - Regionen, die durch eine starke Rolle des Staates geprägt sind. Die öffentlichen Mittel unterliegen immer häufiger der Kontrolle durch staatliche Organe, die auf die ordnungsgemäBe Verwendung Wert legen. Die knappen öffentlichen Budgets und der Wille zur Delegation sind Teil dieser Entwicklung. Im Vordergrund stehen die Ziele und ein klar definierter Aushandlungsprozess. Als Basis dient das in der Betriebswirtschafts- und Führungslehre wohlbekannte „Management by Objectives".

Die Steuerung der Universität läuft in verschiedenen Phasen ab. In einem ersten Schritt geht es um die Erstellung eines Zielkatalogs - meist unter Einbindung der Betroffenen und unter Heranziehung der strategischen Ziele der jeweiligen Institution. Danach folgt die Differenzierung in Formal- und Sachziele. Der Aushandlungsprozess findet in einer dialogischen Form statt und legt schlussendlich fest, in welchem Zeitraum welche Ziele zu erreichen sind. Meist sind mehrere Gesprächsrunden erforderlich. Die Ziele gelten dann aber auch für mehrere Jahre.

Ein Problem des Kontraktmanagements ist die Gefahr der Verpolitisierung und des strategischen Verhaltens. Die einzelnen Einheiten werden weniger Anreize erhalten, für das Gesamtwohl der Institution zu arbeiten als vielmehr für die Interessen der einzelnen Einheit. In jedem Fall ist es ratsam, Kontraktmanagement und Zielvereinbarungen als Steuerungsinstrument nur dann einzusetzen, wenn die Ziele überprüfbar, realistisch, konsistent sind und der Prozess partizipativ und transparent abläuft. Die Verantwortlichkeiten sollten klar definiert, Anreize und Sanktionen verknüpft und ein entsprechendes Controlling und Berichtswesen eingerichtet sein. 


\subsection{Ex-post-und Ex-ante-Steuerung}

Steuerung von autonomen Hochschulen wird sehr oft über eine Input- beziehungsweise Output-Orientierung organisiert (Müller-Böling/Fedrowitz 1998). Dabei spielt es eine entscheidende Rolle, ob Universitäten beispielsweise an der Zahl der Ausbildungsplätze oder der Absolvent/inn/en gemessen werden sollen.

Die Input-Orientierung weist eine vergangenheitsbezogene Vorgehensweise auf. Die Studierendenzahlen, Immatrikulationen, zugewiesenen Mittel oder auch akquirierte Forschungsaufträge werden bereits als Leistung definiert und mit der Rolle der Universität in Verbindung gebracht. Alle Anreizmechanismen laufen in die Richtung, besonders aktive Personen und Prozesse zu belohnen, die Ressourcen akquirieren. Weniger Augenmerk wird auf die internen Prozesse (Throughput) oder die mit diesen Ressourcen erzielten Ergebnisse (Output) gelegt.

Konsequenterweise geht daher eine Input-Orientierung meist mit einer Erhöhung der Studierendenzahlen, der Drittmitteleinnahmen oder der Steigerung des Personalstandes einher. Die Steuerung achtet weniger darauf, was mit den Ressourcen passiert und wie sie zielführend eingesetzt werden können. Die Kapazitätsverordnung mit der Festlegung von Studierendenzahlen in Deutschland ist nur ein Beispiel.

Output-orientierte Steuerung zielt hingegen viel stärker auf die Ergebnisse des Leistungsprozesses ab. Mit eingesetzten Mitteln soll eine optimale Leistung erstellt werden. Der Output wird gemeinsam mit den relevanten Entscheidungsträger/innen definiert.

Diese Vorgehensweise hat den Vorteil, dass die Universitäten und ihre Leitungen auf bestimmte Ziele hinarbeiten können. Sie werden daran interessiert sein, ihre Prozesse entsprechend zu verbessern beziehungsweise zu optimieren. Die Qualität des Leistungserstellungsprozesses rückt in den Mittelpunkt. Insgesamt wird die Universität daran interessiert sein, über Ergebnisse ihre Stellung am Markt zu sichern und auszubauen. Beispielsweise sind die Publikationsleistungen oder die Absolvent/inn/enzahlen ein wichtiger Indikator für den Erfolg einer akademischen Einrichtung. 
2 Die Universitätsreform in Österreich das Universitätsgesetz 2002

Das österreichische Beispiel zeigt, wie die Steuerung autonomer Universitäten entwickelt werden kann. Die Universitätsreform in Österreich hat eine lange Geschichte (Sporn 1999; Titscher, Winckler et al. 2000; Weber 2003). Anfang der 90er-Jahre wurde das österreichische Hochschulsystem grundlegend reformiert. Es kam in der Folge zu mehreren Novellierungen der Universitätsorganisationsgesetze, der Einführung der Fachhochschulen, der Evaluierungsverordnung, der Bologna-Studienarchitektur, der Zulassung von Privatuniversitäten und zuletzt zur Einführung des Universitätsgesetzes 2002. Dieses ist 2004 in Kraft getreten und regelt alle Bereiche des Universitätsgeschehens: Entscheidungsstrukturen, Einrichtung von Studien, Gleichbehandlung, Personalfragen. Im Kern wurden damit die Universitäten in die Autonomie entlassen. Ihr Freiraum vergrößerte sich maßgeblich. Die staatlichen Behörden nahmen ihren Einfluss stark zurück. Als Steuerungsinstrument kamen vor allem das Kontraktmanagement zum Einsatz, das heißt Leistungsvereinbarungen zwischen Ministerium und Universität, sowie Zielvereinbarung zwischen den Rektoraten und den jeweiligen akademischen Einheiten (zum Beispiel Departments oder Institute).

\subsection{Grundprinzipien der Reform}

Im Überblick kann die Reform durch einige Grundprinzipien charakterisiert werden:

- Reduktion der staatlichen Regulierung

- Institutionelle Autonomie

- Zunahme des Wettbewerbs

- Stärkung der Führungsstrukturen an Universitäten

- Effizienzsteigerung

- Neue Beziehung zwischen Universität und Staat

Der staatliche Einflussbereich wurde reduziert. Die Ministerien hatten keinen Einfluss mehr auf die Verwendung der Mittel, die Einstellung von Personal, die innere Organisation oder die Einrichtung von Studien. In diesem Sinn erhielten die österreichischen Universitäten mit dem Universitätsge- 
setz 2002 (UG 2002) Finanz-, Organisations-, Personal- und Programmautonomie. Damit konnte sich das kreative und gestalterische Potenzial der Universitäten entfalten. Sie waren aber auch gefordert, sich auf ihr Profil zu konzentrieren und daraus einen Entwicklungsplan zu erstellen. Eine strategische Planung war die Folge.

Deregulierung führte automatisch auch zu mehr Autonomie. Die Selbstständigkeit im oben beschriebenen Sinn war für Universitäten ein Anreiz, sich durch mehr Selbstständigkeit auch neue Möglichkeiten zu verschaffen. Neue Marktpositionen, leichter einzurichtende Studien, ein mehr an Flexibilität waren die Folgen. Es konnten neue Positionen geschaffen und Personen aus dem Ausland zu attraktiven Konditionen für die Universitäten gewonnen werden.

Damit einhergehend war auch mehr Wettbewerb innerhalb der Universitäten und zwischen den Institutionen verbunden. Durch die Entwicklungspläne geben sich die Universitäten eine Strategie, wie sie sich mittelfristig am Bildungsmarkt positionieren wollen. Vor allem die Professuren und die strategischen Handlungsfelder in der Lehre spielen dabei eine besondere Rolle. Für die Internationalisierung ist der Wettbewerb wichtig. Benchmarks mit anderen Universitäten spielen eine immer größere Rolle. Zusätzliche Finanzmittel für Infrastruktur oder Forschung werden in einem Wettbewerbsverfahren vergeben und dienen dazu, die Besten zu selektieren. Insgesamt soll sich der Hochschulraum Österreichs verbessern und international stärker wahrgenommen werden.

Im Zuge der Universitätsreform wurde auch die Führung an Hochschulen gestärkt. Die Rektorate sind dazu berufen, die Universität strategisch, organisatorisch, personell und finanziell nach klaren und transparenten Prinzipien zu führen. Sie sind einem externen Aufsichtsgremium verantwortlich (Universitätsrat). Der Senat wurde in seiner Stellung verändert und ist nun vor allem für Studienfragen und Berufungen zuständig. Entwicklungs- und Organisationsplan kommen vom Rektorat. Die Satzung ist vom Senat zu bestimmen. Ein neues Miteinander ist seitdem an Universitäten in Österreich gefordert. Das Zusammenspiel wird durch das Prinzip der doppelten Legitimation geregelt. Vorschlagsrecht auf der einen Seite und Entscheidungsrecht auf der anderen Seite sollen garantieren, dass beide Seiten gut aufeinander abgestimmt agieren können.

Effizienz ist ein wichtiges Stichwort der Reform. Durch die neue Universitätsorganisation sollte die Effizienz des Universitätsgeschehens maßgeb- 
lich verbessert werden. Eingesetzte Ressourcen müssen optimal verwendet und die Zielerreichung sollte kontrolliert werden. Effizientes Management sollte sich dabei auf schnelle Entscheidungsprozesse und die Klarheit der Ziele beziehen. Dadurch können Universitäten schneller auf Veränderungen reagieren.

Die Beziehung zwischen Staat und Universität war einem besonderen Wandel unterzogen. Gerade bei der Gewährung von umfassender Autonomie an Universitäten ist die Neuregelung dieser Relation von zentraler Wichtigkeit. Zum einen bleibt es im Interesse des Staates, auf die öffentlich finanzierten Institutionen weiterhin steuerende Wirkung auszuüben. Zum anderen impliziert Autonomie auch die Möglichkeit, den Hochschulen einen möglichst großen Handlungsspielraum zu gewähren. In Österreich wurde dem durch zwei Instrumente Rechnung getragen: Leistungsverträge und Globalbudgets.

Leistungsverträge dienen dazu, eine Vereinbarung zwischen Staat und Universität abzuschließen. Darin ist der Leistungsumfang definiert und an eine entsprechende Finanzierungsgarantie geknüpft. Der Staat hat damit auch die Möglichkeit, im Rahmen von Verhandlungen bestimmte Leistungen im Detail vorzusehen. Die Universitäten haben im Gegenzug die Möglichkeit, ihre Leistung an ein entsprechendes Finanzierungsversprechen zu knüpfen. Die Globalbudgets dienen dazu, die Universität nicht in ihrer Autonomie einzuschränken. Sie können frei über ihre Mittel verfügen und festlegen, wofür Budgets verwendet werden.

\subsection{Neue Führungsstrukturen an Universitäten}

Die erfolgreiche Steuerung von autonomen Universitäten hängt zu einem guten Teil von den Führungsstrukturen ab. An wesentlichen Leitungsorganen sind an österreichischen Universitäten der Universitätsrat, das Rektorat und der Senat eingerichtet. Wie bereits erwähnt hat die Reform des UG 2002 eine Verschiebung der Macht vom Senat in Richtung Rektorat gebracht. Der Universitätsrat agiert als eine Art Aufsichtsrat und ist für die Kontrolle zuständig, bestellt den/die Rektor/in, beschließt den Organisations- und Entwicklungsplan und nimmt das Budget zur Kenntnis. Die Mitglieder müssen alle von außerhalb der Universität kommen, wobei die Hälfte auf Vorschlag des Senats und die Hälfte vom Ministerium bestellt 
werden. Das Rektorat kann aus maximal fünf Personen bestehen und führt das Alltagsgeschäft an der Universität. Damit fungiert es als eine Art Vorstand, der Strategie und Funktionalbereiche (zum Beispiel Studien, Finanzen, Personal, IT, Marketing, Internationales) abdeckt. Der Senat ist für ganz bestimmte Bereiche zuständig, vor allem für Studien- und Berufungsangelegenheiten. Er ist die Einrichtung der universitären Selbstverwaltung und bietet allen vertretenen Gruppen (Professor/inn/en, Mittelbau, Verwaltung, Studierenden) die Möglichkeit der Mitbestimmung. Durch diese Struktur soll Verantwortung und Entscheidung in eine Hand gelegt werden und die Hochschulen zu modern geführten Institutionen mutieren.

Als Resultat dieser Reform wurden die monokratischen Organe eindeutig gestärkt. Rektorate, aber auch Department-Vorstände erhalten eine größere Machtfülle. Sie haben finanzielle Mittel zur Verfügung, um ihre Entscheidungen auch entsprechend umzusetzen. Gleichzeitig wurde die Bedeutung der Kollegialorgane zurückgedrängt und auf ganz spezifische Bereiche fixiert. Dadurch sollte vermieden werden, dass Senate über Budgets entscheiden, ohne selbst für die Umsetzung verantwortlich zu sein. Gleichzeitig sollten die Senate über Studien entscheiden, die aus curricularer Sicht Sinn machen. Dennoch bleibt es den Rektoraten vorbehalten, über die Finanzierung der Studien auch deren tatsächliche Einführung zu entscheiden. Schlussendlich hat das Ministerium einen Rückzug aus der Alltagsarbeit der Universitäten angetreten. Sein Einfluss ist auf die Steuerung von Dreijahresverträgen und die Finanzierung beschränkt. Durch gesetzliche Rahmenbedingungen wird dafür gesorgt, dass die Universitäten ihrem öffentlichen Auftrag nachkommen.

\subsection{Steuerungsansatz der österreichischen Universitätsreform}

Der Steuerungsansatz für österreichische Universitäten folgt vier Prinzipien:

1. Von der bürokratischen zu einer unternehmerischen Universität (Wettbewerbsorientierung)

Wie bereits erwähnt, soll der unternehmerische Gedanke besondere Aufmerksamkeit erlangen. Dies wird durch eine klare Wettbewerbsorientierung massiv gefördert. Die Universitäten treten untereinander in Wettbewerb und auch innerhalb der Institutionen sollen Wettbewerbsbedingungen ge- 
schaffen werden. Dies geschieht vor allem dadurch, dass Förderungen auf Antragsbasis vergeben, Projekte definiert und Kooperationen innerhalb und zwischen Universitäten und anderen Bildungseinrichtungen besonders gefördert werden.

\section{Management mit Zielvorgaben}

Leistungsvereinbarung zwischen Ministerium und Universität sowie Zielvereinbarungen innerhalb der Universität sind die Konkretisierung des klaren „Management by Objectives“-Ansatzes der österreichischen Universitätsreform. Über Ziele soll das gesamte System gesteuert werden. Die entsprechenden „Verträge“ basieren auf einem Aushandlungsprozess zwischen den Verhandlungspartnern. Vorschläge für Ziele und deren Erfüllung werden an Finanzierungszusagen geknüpft. Das gesamte Geschehen erhält durch diese Vorgehensweise eine politische Dimension. Die Akteure achten auf ihre Interessen und versuchen diese durchzusetzen. Die Chance besteht vor allem darin, dass dadurch mehr strategisches Denken über die jeweilige Zukunftsperspektive entsteht und eine Übereinstimmung mit der Gesamtstrategie der Institution hergestellt wird.

\section{Leistungsindikatoren}

Um Ziele auch messbar zu machen, bedarf es der Entwicklung von Leistungsindikatoren. In der österreichischen Reform sind daher Wissensbilanz und Formelbudget eingeführt worden. Die Wissensbilanz soll das intellektuelle Kapital jeder Universität durch ein umfangreiches Bündel an Messzahlen darstellen. Die Palette reicht von Indikatoren zur Lehre, Forschung, Drittmitteleinnahmen, Internationalisierung, Raum und Berufungen. Die jährliche Darstellung verhilft allen Steuerungsorganen - vor allem Rektorat, Universitätsrat und Ministerium - zu einem wichtigen Steuerungsinstrumentarium. Das Formelbudget setzt ergänzend dazu Anreize in eine ganz bestimmte Richtung. 20 Prozent des Globalbudgets werden für das Formelbudget einbehalten. 80 Prozent werden über die Leistungsvereinbarungen vergeben. Im Formelbudget sind Indikatoren zu den Studierendenzahlen, zu den Forschungsdrittmitteln, zur Frauenförderung und zur Studierendenmobilität enthalten. 


\section{Fokus auf Stärken, Profilbildung, Schwerpunkte}

Wichtiges Steuerungselement der Reform ist die Frage der Profilbildung. Im Rahmen der Entwicklungsplanung legt jede Universität fest, wo die jeweiligen Stärken und Schwächen beziehungsweise Chancen und Risiken liegen. Das bietet dann die Basis für eine umfassende strategische Planung. Als Resultat entstehen Schwerpunkte, in die die Institution besonders investieren beziehungsweise diese ausbauen will. Wichtig dabei ist, dass damit eine starke Position im Wettbewerb erarbeitet wird, um sich so von der Konkurrenz abzuheben. Aus diesen Analysen und den daraus entstehenden Schwerpunkten resultiert dann insgesamt ein institutionelles Profil. Aus Sicht des Ministeriums entsteht auch die Möglichkeit, nationale Profilbildung zu betreiben und Überlappungen beziehungsweise fehlende Bereiche zu erkennen und entsprechend gegensteuern zu können.

Zwei Einschränkungen sind bedeutsam: der freie Hochschulzugang und die gesetzlich geregelten Studiengebühren. In einem Wettbewerbsumfeld autonomer Universität wäre es eigentlich nur logisch, auch alle entsprechenden Instrumente zur Verfügung zu haben, um das freie Spiel von Angebot und Nachfrage zielgerecht nützen zu können. Per Gesetz sind aber die Nachfrage (Hochschulzugang) und die Preise (Studiengebühren) geregelt. Die Universitäten sind also fundamental in ihrem Handlungsspielraum eingeschränkt und noch viel mehr - sie sind gegenüber den österreichischen Fachhochschulen massiv benachteiligt. Diese haben nämlich die Möglichkeit, die Anzahl der Studierenden nach Kapazität und mit einer gesicherten öffentlichen Studienplatzfinanzierung zu regeln. Für Universitäten in Österreich gilt hingegen, dass sie alle Studieninteressierten mit Matura oder gleichwertiger Qualifikation aufnehmen müssen. Darüber hinaus sind die Gebühren geregelt, das heißt für ein Regelstudium fallen in Österreich derzeit keine Gebühren an (Ausnahmen sind Weiterbildungsangebote). Damit sind die Universitäten im Wettbewerb extrem benachteiligt und das System insgesamt verzerrt. Es entstehen überlastete Massenfächer, die sich nur schwer im internationalen Wettbewerb bewähren können. Dieser Zustand beeinträchtigt die umfassende Universitätsreform in Österreich. 


\subsection{Interne Steuerung: Prinzipien der unternehmerischen Universität}

Die österreichische Reform kann also durch eine Wettbewerbsorientierung charakterisiert werden, die danach trachtet, unternehmerisches Agieren auf Seiten der Universitäten zu fördern. Dabei spielt ebenfalls eine Reihe von Prinzipien eine entscheidende Rolle:

- Universität als Dienstleistungsorganisation

- Förderung von Innovation und Konkurrenz

- Effizienz-, Ergebnis- und Serviceorientierung.

Universitäten in Österreich werden nicht mehr als nachgeordnete Dienststellen des Staates empfunden oder als bürokratische Einrichtung zur Verwaltung von Universitätsgesetzen. Sie sind vielmehr moderne Dienstleister, die sich den Prinzipien der Kundenorientierung verschrieben haben. Dabei wird aber der/die Studierende oder auch der/die Mitarbeiter/in nicht notwendigerweise als Kunde/Kundin im engeren Sinn gesehen. Die Gruppen sind vielmehr Mitglieder der Organisation Universität und an der erfolgreichen Leistungserstellung unmittelbar beteiligt. In der Verwaltung jedoch geht es um die Serviceleistungen für die Gruppen, sie mit aktuellen Informationen und Leistungen zu versorgen, um so die Leistung insgesamt $\mathrm{zu}$ steigern. Als Beispiele können eine einwandfreie IT-Infrastruktur, ein Beratungszentrum oder die Prüfungsabwicklung gesehen werden.

Eine positive Einstellung zu Innovation und Konkurrenz spielen in diesem Zusammenhang eine große Rolle. Innerhalb der Universität werden die Erneuerungskräfte gefördert und eine stärkere Konkurrenz angestrebt. Die Mechanismen und Anreize laufen in die Richtung, dass Innovation gefördert wird und Mittel oft nach dem Prinzip des Wettbewerbs vergeben werden. Dadurch soll die Qualität insgesamt angehoben werden.

Durch die Herausbildung eines Entwicklungsplans und einer Strategie ist die Orientierung an den Zielen der Universität wesentlich. Alle Maßnahmen und Aktivitäten sollen auf die Gesamtvision abgestimmt sein und im Hinblick auf deren Beitrag zur Zielerreichung bewertet werden. Die eingesetzten Mittel sollen effizient eingesetzt werden.

Darüber hinaus kommt der Ergebnisorientierung Bedeutung zu. Das Universitätsmanagement beschäftigt sich damit, definierte Outputs zu erreichen. Interne Leistungsvereinbarungen stehen dafür zur Verfügung. Sie 
basieren auf einem Aushandlungsprozess und zeigen, was eine akademische Einheit zum Gesamtergebnis der Universität beitragen kann. Die Mittelzuweisung erfolgt dementsprechend. Nur bei einem klaren Vereinbarungsergebnis kommt es zur finanziellen Förderung des jeweiligen Bereichs.

Die Serviceorientierung ist ganz wesentlich für die unternehmerische Universität. Die Wünsche und Bedürfnisse aller beteiligten Universitätsangehörigen sollten im Vordergrund stehen, und die Erfüllung drückt sich in der Neugestaltung der Leistungsprozesse aus. So werden die Studien- und Prüfungsabteilungen, die Internationalen Büros oder auch die Rektorate nach dieser Serviceorientierung bewertet.

\subsection{Externe Steuerung: Vorgaben durch das Universitätsgesetz}

Die externe Steuerung der Universitäten geschieht über das Ministerium und Gesetze, die zu Konflikten führten. Dazu gehören die Selbstverwaltung, die Zielvereinbarungen, die zentrale Regelung der Studiengebühren sowie die Kontrolle über den Hochschulzugang.

Einige Konfliktfelder bestehen zwischen Universitätsrat, Rektorat und Senat. Beispielsweise betrifft das die Wahl des Rektors/der Rektorin. Der Universitätsrat ernennt den/die Rektor/in. Der Rektor/in schlägt sein/ihr Team dem Universitätsrat zur Bestellung vor. Auch die Entwicklungspläne werden von den Rektoraten erstellt und vom Universitätsrat verabschiedet. Der Senat hat damit an Macht und Einfluss verloren. Das wird aber durch das Prinzip der doppelten Legitimation gemildert: Der Wahlvorschlag für den/die Rektor/in wird vom Senat erstellt, und die Entwicklungspläne müssen dem Senat zur Kenntnis gebracht werden. So werden wesentliche Entscheidungen jeweils von allen Parteien getragen, um die Nachhaltigkeit und die erfolgreiche Implementierung sicherzustellen.

Die Finanzierung der Reform ist ein wichtiges Steuerungsinstrument. Um autonome und unternehmerische Einrichtungen entstehen zu lassen, bedarf es zusätzlicher Ressourcen. Jedoch sind die permanente Unterfinanzierung der österreichischen Universitäten sowie die zentrale Regelung der Studiengebühren und der Zugang zu Hochschulen erschwerende Faktoren. Universitäten haben nicht genügend Spielraum, um ihre Pläne umsetzen 
zu können. Sie sind hier an externe Bedingungen gebunden. Für kurze Zeit gab es Studiengebühren in Österreich (2001-2009). Aus politischen Gründen wurden diese wieder abgeschafft und mit dem freien Hochschulzugang verknüpft. Damit stehen zwei wesentliche Steuerungsmechanismen nicht mehr zur Verfügung. Der (internationale) Wettbewerb wird dadurch erschwert. Unternehmerische Kräfte sind umso mehr gefordert.

3 Erfahrungen einer autonomen Universität:

Wirtschaftsuniversität Wien (WU)

Die Erfahrungen einer bestimmten österreichischen Universität sollen das unternehmerische Prinzip verdeutlichen und illustrieren. Die Wirtschaftsuniversität Wien (WU) gehört heute zu den Top 5 im deutschsprachigen Raum und ist damit eine der wichtigen Wirtschaftshochschulen in Europa. Hier wird ein kurzer Überblick geliefert, welchen Weg die WU in den letzten Jahren beschritten hat (Sporn 1999; Badelt 2003).

\subsection{WU als autonome und unternehmerische Universität}

Die WU versteht sich als unternehmerische Universität und begann mit der Umsetzung der Idee gleichzeitig mit der Einführung des UG 2002. Als generelles Ziel gilt, dass die WU zu den Top 5 im deutschsprachigen Raum und zu den Top 15 in Europa zählen will. Erreicht wird dieses Ziel durch die Ausdifferenzierung in Bachelor- und Masterprogramme sowie eines umfassenden Angebots an PhD-Studien. Die Bologna-Studienarchitektur wird flächendeckend an der WU seit 2006 umgesetzt.

Die WU hat bewiesen, dass sie offen für Veränderung ist und sich dem Wettbewerb in einem internationalen Kontext stellen will. Das BolognaSystem dient dazu, verschiedene Märkte zu definieren und die Programme danach auszurichten. So sind die Bachelorprogramme für den regionalen Markt, die Master-Programme für Europa und die PhD-Programme für die weltweite Zielgruppe positioniert. Die postgradualen Programme zielen vor allem auf den zentraleuropäischen Markt ab.

Die Qualitätsprüfung durch eine internationale Akkreditierung stellt ein wesentliches Instrument dar, um die Universität auch nach außen als exzel- 
lent darzustellen. Dabei sollen jene Agenturen in Betracht kommen, die weltweit Anerkennung finden und wesentliche Merkmale wie internationale Ausrichtung der Universität oder Verbindung zur Wirtschaft prüfen. Die Qualität in Lehre und Forschung steht dabei im Mittelpunkt. Die WU stellt sich dabei erstmalig der Prüfung durch externe Evaluationen.

Die mehrfach erwähnte Output-Orientierung statt einer Input-Maximierung (zum Beispiel durch Leistungsverträge mit den Departments) steht im Vordergrund. Diese Output-Orientierung zieht sich durch die gesamte Universität. Das Rektorat schließt Zielvereinbarungen mit dem Universitätsrat ab. Dieses wiederum vereinbart Ziele mit den Departments. Insgesamt soll daraus ein Bündel an miteinander in Verbindung stehenden Zielen entstehen.

Ein neues strategisches Konzept bildet die Basis der Entwicklung. Die Etablierung einer „Undergraduate School“ (für die Bachelor-Programme), einer "Graduate WU“ (für Master und PhD), der Forschungsinstitute und Kompetenzzentren für die Wirtschaft sowie die Executive Academy als Anbieter postgradualer Programme ist dabei handlungsleitend. Für den angloamerikanischen Bereich mag es keine besondere Neuerung sein. Für den österreichischen Markt ist diese Vorgehensweise doch sehr innovativ.

Auch die neue Departmentstruktur der WU weist in diese Richtung. Aus mehr als 60 Instituten wurden zwölf Departments geschaffen. Sie werden von einem Vorstand geleitet, der für die strategische Ausrichtung, Personalfragen und Budgetfragen zuständig ist. Die Departments sind das wesentliche Gegenüber des Rektorats und bestimmen das Geschehen an der WU maßgeblich. Für den Nachwuchs entsteht eine größere Einheit, die Orientierung bieten kann.

Bereits erwähnt wurde die Serviceorientierung gegenüber verschiedenen "Stakeholdern“ (zum Beispiel Wirtschaft, Studierende). Die WU sieht sich hier als Vorreiter durch verschiedenste Einrichtungen, die eine gute Abstimmung sicherstellen sollen. Die Dienstleistungen sind auf die einzelnen Zielgruppen genau abgestimmt.

Die WU hat aber auch Verantwortung gegenüber der Gesellschaft und sieht es als eine wesentliche Aufgabe, ihre unternehmerischen Kräfte auch in den Dienst der Allgemeinheit zu stellen. So sollen die Bachelorprogramme einer möglichst großen Zahl ein Studium ermöglichen. Der öffentliche Bildungsauftrag und der Wunsch, dies mit einem qualitativ hochwertigen 
Studium zu kombinieren, um vielen Absolvent/inn/en ein erfolgreiches Berufsleben zu ermöglichen, stehen im Vordergrund.

Gleichzeitig setzt die unternehmerische WU auch auf gewinnorientierte Aktivitäten in einem Nonprofit-Umfeld. Durch die Aktivitäten der Executive Academy werden die postgradualen Programme der WU gegen Marktpreise angeboten. Die Academy ist als Profit-Center konzipiert und soll zusätzliche Mittel gewinnen. Die kreativen und innovativen Programme helfen dabei, die WU auch in diesem Marktsegment als Top-Anbieter zu etablieren.

\subsection{Bisherige Zielerreichung der unternehmerischen WU}

Die WU hat sich große Ziele gesetzt. An dieser Stelle sind die wesentlichsten Umsetzungsschritte genannt:

1. Die WU wurde 2007 als eine von fünf Universitäten im deutschsprachigen Raum mit einer EQUIS-Akkreditierung ausgezeichnet. EQUIS steht für European Quality Improvement System und misst die Qualitätsstandards von Wirtschaftshochschulen mit besonderem Fokus auf die strategische Ausrichtung, die Internationalisierung und die Verbindung zur Wirtschaft.

2. Die WU hat 2006 komplett auf das Bologna-Studiensystem umgestellt. Es werden zwei Bachelorprogramme (Wirtschafts- und Sozialwissenschaften, Wirtschaftsrecht), 14 Masterprogramme (die Hälfte davon auch in Englisch) und PhD-Programme angeboten.

3. Die Rankings der Jahre 2008 und 2009 zeigen den Erfolg der WU. Die „Financial Times“ reihte das Diplomstudium Internationale Betriebswirtschaft auf Platz 18 (von 54) und das Executive MBA auf Platz 51 (von 100). Die Tageszeitung „Handelsblatt“ setzte die WU auf Platz fünf im deutschsprachigen Raum unter allen Fakultäten der Sozial- und Wirtschaftswissenschaften.

4. Die WU weist in ihrem Entwicklungsplan ein klares Forschungsprofil auf, das sieben Schwerpunkte der WU-Forschung definiert:

- Computing, Informationstechnologie und Entscheidungsunterstützung

- Finanzwirtschaft

- Innovation, Kommunikation und Information in und zwischen Unternehmen und Institutionen 
- International Tax Coordination

- Wachstum, Beschäftigung und Wettbewerbsfähigkeit in Europa

- Wirtschaftsrecht

- Zentraleuropäischer Wirtschaftsraum

5. Die Leistungsvereinbarungen mit dem Ministerium werden regelmäßig in die interne Planung aufgenommen. Es wird daraus eine Art „Business Plan“ erstellt, auf dessen Basis Finanzierungsentscheidungen getroffen werden. Die dreijährige Periode mit dem Ministerium wird auch intern gespiegelt und mit den Departments entsprechend vereinbart.

6. Die WU hat sich im Laufe der Jahre auch neue Strukturen gegeben. Es sind zwölf Departments entstanden. 14 Forschungsinstitute, die interdisziplinär und departmentübergreifend an aktuellen Themen arbeiten. Meist werden diese von Unternehmen oder Einrichtungen des öffentlichen Sektors gefördert. Programmdirektor/inn/en managen die Studienprogramme und sind von Curricular-Erstellung und Qualitätssicherung bis zum Marketing für das Programm zuständig. Sie „,kaufen“ Leistungen von den Departments, um die Programme erfolgreich anbieten zu können.

7. Bereits erwähnt wurde die Differenzierung der WU-Strategie: Undergraduate School, Graduate WU, Forschungsinstitute und Kompetenzzentren, WU Executive Academy. Diese vier Eckpfeiler dienen dazu, die WU in verschiedenen Märkten zu positionieren und unterschiedliche Studierende und andere "Stakeholder" anzusprechen. Die Programme sind bereits etabliert, die neuen Strukturen werden in den nächsten Jahren folgen.

8. Insgesamt will die WU sich verstärkt international positionieren und auch rekrutieren. Studierende und wissenschaftliches Personal sollen vermehrt einen internationalen Background aufweisen. Die Bemühungen reichen von proaktiver Suche nach Professor/inn/en bis hin zur Vertretung der WU bei internationalen Medien und Messen. Dafür wurde ein neues Corporate Design und Logo entwickelt.

\subsection{WU-Erfahrungen externer Steuerung:}

Leistungsvereinbarungen

Die Erfahrungen der WU mit externer Steuerung werden hier beispielhaft anhand der Leistungsvereinbarungen zwischen Ministerium und Wirtschaftsuniversität Wien illustriert. Die WU hat bereits eine Periode abge- 
schlossen, die bestehenden Vereinbarungen wurden 2007 abgeschlossen. Dem vorausgegangen ist ein aufwendiger Prozess der Erstellung eines Entwurfs, in dem sowohl auf die Lage der Universität insgesamt als auch auf einzelne besondere Projekte zum Zwecke der Profilbildung eingegangen wurde. Dabei wurde im Dokument zwischen Vorhaben und Zielen unterschieden, wobei für beide Bereiche entsprechender Output definiert wurde. Das gesamte Programm wurde entsprechend mit „Preisen“ versehen und diente als Basis für die Gespräche. Als Ergebnis konnte die WU einen Schwerpunkt definieren, der besonders gefördert wurde, und erlangte in den Verhandlungen eine Budgetsteigerung von zehn Prozent (zuzüglich Inflationsabgeltung) im Vergleich zu den Vorjahren. Die WU erhielt damit ein Drei-Jahres-Globalbudget, das autonom von der WU-Führung verteilt werden konnte. Es wurden dadurch Engpässe vor allem in den Bachelorstudien beseitigt, ein Schwerpunkt für Mittel- und Osteuropa und die weitere Internationalisierung der WU besonders gefördert und ausgebaut. Über die Erfüllung der Leistungsvereinbarung musste jedes Jahr ausführlich an das Ministerium berichtet werden.

Insgesamt lassen sich die Erfahrungen in zwei Teile trennen. Zum einen stellte sich heraus, dass die Steuerung stark abhängig von politischen Willen der jeweiligen Parteien getrieben war und dass wenig Bezug zur eigentlichen Problemsituation bestand. Auf die Situation der WU mit ihren hohen Studierendenzahlen, den Kapazitätsengpässen und dem Willen zur internationalen Positionierung wurde wenig eingegangen. Die Gespräche hatten also wenig Bezug zum eigentlichen Kerngeschäft der WU. Zum anderen kann der Prozess eben durch das Fehlen einer inhaltlichen Orientierung als stark politisch charakterisiert werden. Die Leistungsvereinbarungen fordern dazu auf, sozial erwünschte Themen zu präsentieren. Die Universitäten überlegen sich also, welche Themen angeschnitten werden und welche auf große Zustimmung stoßen müssten. Auch das Verhandlungsgeschick, die Art der Gesprächsführung und die Präsentation des Leistungsvereinbarungsentwurfs spielen in einer solchen Situation eine wichtige Rolle. Die Interessen der beiden Verhandlungsparteien müssen im Vorfeld gut bekannt sein und sollten antizipiert werden können. 


\subsection{Erfahrungen mit der Steuerung innerhalb der WU}

Die WU hat auf Basis der Leistungsvereinbarung mit dem Ministerium auch Zielvereinbarungen mit den Departments abgeschlossen. Wie bereits erwähnt, wurde das Verhältnis der Entscheidungsgremien maßgeblich durch das UG 2002 verändert. Der Entwicklungsplan wird vom Rektorat erstellt - allerdings auf Basis einer Abstimmung mit wichtigen Vertreter/inn/en des Senats. Die Satzung kommt vom Senat, wird aber auch in enger Abstimmung mit dem Rektorat entwickelt. Die Studienpläne, eine Kernaufgabe des Senats und seiner Studienkommission, werden von Programmverantwortlichen erstellt, mit dem Rektorat abgestimmt und dann entschieden. Insofern wird an der WU das Prinzip der doppelten Legitimation klar gelebt.

Die interne Steuerung einer autonomen Universität wie der WU hat auch Spannungsfelder im wissenschaftlichen Bereich gebracht. So steht seit einigen Jahren oftmals die Autonomie der Professor/inn/en im Gegensatz zur Autonomie der Institution. Beispielsweise ist die Freiheit der Lehre dadurch eingeschränkt, dass gewisse Studienpläne nach internationalen Standards entwickelt werden müssen. Die Evaluation ist für alle Bereiche und in regelmäßigen Abständen vorgeschrieben. Die Transparenz der Leistungen ist eine Notwendigkeit, um Einblicke in die Stärken und Schwächen zu erlangen. All dies schränkt die vormals breite Freiheit der Professor/inn/en ein und liefert der Universität wichtige Impulse zur Weiterentwicklung.

Die Zielvereinbarungen mit den Departments basierten auf einer Selbstbeschreibung. Es konnten spezielle Projekte und daraus abgeleitete Ressourcenwünsche präsentiert werden. Auf der Basis wurden dann mehrstündige Gespräche zwischen Rektorat und Department-Vertreter/innen geführt, die auf den gesamten Text eingingen und Ziele vereinbarten.

Es zeigte sich, dass ein Dialog mit den Departments über die Belastung und Pläne in Lehre und Forschung gestartet wurde. Es konnte dadurch mehr Transparenz und Offenheit erzeugt werden. Die Departments erhielten die Möglichkeit, sich zu präsentieren. Das Rektorat konnte Stärken erkennen. Es wurde damit eine Entwicklung ausgelöst, die sowohl den Departments als auch der WU insgesamt hilft, im Sinne einer Stärkung von Stärken weiterzuarbeiten. Das Rektorat achtete klar darauf, dass eine Übereinstimmung mit dem Entwicklungsplan stattfand. Der Prozess war zwar sehr aufwendig und neu für die WU; der Datenbedarf war ausgeprägt. Das 
Rektorat erhielt erstmals ein Bild über die Departments und deren Angehörige. Spezifische Anliegen des Rektorats, wie beispielsweise die Frauenund Nachwuchsförderung, wurden durch die spezielle "Ausschreibung" von Stellen im Rahmen der Zielvereinbarungen besonders betont.

\section{Resümee}

Die Steuerung einer autonomen Universität stellt gerade für Universitäten im deutschsprachigen Raum eine Chance und Herausforderung dar. Das österreichische Beispiel zeigt, dass Vorteile entstehen, die Universitäten wie der WU dazu verhelfen, sich im internationalen Markt erfolgreich zu bewähren und intern die Prozesse in Lehre und Forschung zu verbessern. Es kann eine neue Art der Universität entstehen, die auch für den jeweiligen Standort von großem Nutzen ist.

Dazu gehört die Sichtweise, die Autonomie als Chance zu begreifen. Freiheit und Flexibilität ermöglichen Handlungsspielraum. Diesen zu nutzen und das unternehmerisch zu begreifen kann eine neue Entwicklung einleiten. Die WU konnte davon profitieren. Ohne Autonomie wäre diese Entwicklung undenkbar gewesen.

Wichtig ist auch, die politischen Prozesse genau zu beobachten. Die WU wie viele andere Universitäten in Europa - ist öffentlich finanziert und stark von gesetzlichen Vorgaben anhängig. Der Einflussbereich von Regierungen und Gesetzgeber muss daher immer beachtet werden und spielt für ein erfolgreiches Management eine wichtige Rolle. Gute Verbindungen in die Politik, geschicktes Lobbying und klare Kommunikation der Universitätsbedürfnisse gehören zur Praxis in dieser Situation.

Innerhalb der Universität ist das „Buy-in“ der Universitätsangehörigen sicherzustellen. Keine Reform wird erfolgreich implementiert werden können, wenn die Betroffenen nicht auch einbezogen werden. Es sollten Prozesse geschaffen werden, die die Möglichkeit der Partizipation bieten. Damit können die unterschiedliche Hintergründe, Wünsche und Bedürfnisse berücksichtigt werden.

Die Leistungsvereinbarungen haben auch gezeigt, dass eine Kohärenz von Strategie und Budgetierung (,Business Plan“) eine entscheidende Rolle spielt. Die Universität muss in der Lage sein, ihre Strategie auch mit Prei- 
sen zu versehen und daraus dann die Implementierung abzuleiten. Die in der Vergangenheit gewählte Trennung von Entscheidung und Verantwortung ist damit zu Ende.

Darauf aufbauend hat sich gezeigt, dass nur eine langfristige Sichtweise und eine klare Perspektive den Erfolg einer autonomen Universität bestimmen. Kurzfristige Ziele werden sich weniger in den Entwicklungsplänen finden und Maßnahmen müssen antizipieren, welche Wirkung auf das Gesamtgeschehen an der Universität entsteht.

Für den Erfolg und das professionelle Management hat sich der Bedarf nach einem durchgängigen Indikatorensystem gezeigt. Dadurch wird Transparenz geschaffen, die wichtig ist, um die Bedingungslage genau zu kennen. Vor allem die Entscheidungsqualität wird sich dadurch maßgeblich verändern. Für die Betroffenen und die Außenstehenden werden Entscheidungen nachvollziehbar. Die eigene Leistung kann besser eingeordnet und mit den Zielen der Universität in Beziehung gesetzt werden.

Das Streben nach internationaler Ausrichtung kann als Hebel fungieren. Die WU hat sich entschieden, zu den Spitzeninstitutionen zu gehören. Das bewirkt eine Analyse von Vergleichsinstitutionen und der stärkeren Einbeziehung von internationalen Standards. Eine Akkreditierung oder Benchmarking sind wichtige Maßnahmen in dem Zusammenhang. Für die Universitätsangehörigen kann daraus Motivation entstehen, zu den Besten im Feld zu gehören.

Für die Internationalisierung sind Profil und Schwerpunkte zentral. Keine Universität kann in alle Bereichen die Spitze erreichen. Knappe Ressourcen sind im Wettbewerb zu vergeben. Der Wettbewerb erfordert die klare Kommunikation eines bestimmten Charakters einer Institution. Dazu sind eine klare Profilbildung und auch Schwerpunkte notwendig. Für die WU war der Prozess der Profilbildung ein ganz wesentliches Element, die gesamte WU zusammenzubringen und zu überlegen, wo Exzellenz erreicht werden kann. Schwerpunkte verhelfen damit der Entwicklung von Spitzenleistungen und der Positionierung im internationalen Markt zum Durchbruch.

Ein Klima für Veränderungen zu schaffen zählt zu den wichtigsten und schwierigsten Aufgaben des Managements von autonomen Universitäten. Für die Universitätsangehörigen muss klar werden, warum ein Wandel notwendig und welcher Nutzen damit verbunden ist. Das Renommee, der Ruf und schlussendlich der Stolz auf die Universität können bei vielen den 
Willen zur Veränderung auslösen. Es wird immer ein Balanceakt sein, die Zweifelnden und die Befürworter zusammenzubringen, um den Erfolg gewährleisten zu können. Wichtig ist vor allem, ein gemeinsames klares Bild über die Zukunft der Universität zu entwickeln und auch zu kommunizieren. Dann haben zumindest alle die Möglichkeit, sich damit zu identifizieren und damit die wichtigen Schritte der Weiterentwicklung mitzutragen.

Autonome Universitäten in Österreich haben viele Möglichkeiten. Wie gezeigt wurde, kann das Potenzial nur durch ein Zusammenspiel verschiedener Kräfte voll ausgeschöpft werden. Die Instrumente und Maßnahmen sind genau zu bewerten. Insgesamt bietet Autonomie die Chance, eine Universität der Zukunft zu gestalten, die vielen Generationen von Lehrenden, Forschenden und Lernenden einen spannenden Ort der Auseinandersetzung, des Studiums und der Forschung bietet.

\section{Literatur}

Badelt, C. (2003): Die unternehmerische Universität: Herausforderung oder Widerspruch in sich? Wien.

Baldridge, J. V. (1983): Organizational Characteristics of Colleges and Universities. In: J. V. Baldridge; Deal, T. (Hg.): The Dynamics of Organizational Change in Education. Berkeley, CA, S. 38-59.

Birnbaum, R. (1989): How Colleges Work: The Cybernetics of Academic Organization and Leadership. San Francisco.

Clark, B. R. (1983): The Higher Education System: Academic Organization in Cross-National Perspective. Berkeley, CA.

Cohen, M. D.; March, J. G. (1974): Leadership and Ambiguity: The American College President. Boston.

Fedrowitz, J., Krasny, E. et al. (Hg.) (1999): Hochschulen und Zielvereinbarungen. Gütersloh.

Höllinger, S.; Steinbacher, W. (1992): Selbstorganisation und Management gegen Bürokratie. In: Altrichter, H.; Schratz, M. (Hg.): Qualität von Universitäten. Innsbruck, S. 43-57.

Mintzberg, H. (1979): The Structuring of Organizations. Englewood Cliffs, NJ.

Müller-Böling, D.; Fedrowitz, J. (Hg.) (1998): Leitungsstrukturen für autonome Hochschulen. Gütersloh. 
Sporn, B. (1999): Adaptive University Structures: An Analysis of Adaptation to Socioeconomic Environments of US and European Universities. London.

Titscher, S.; Höllinger, S. (Hg.) (2004): Die österreichische Universitätsreform: Zur Implementierung des Universitätsgesetzes 2002. Wien.

Titscher, S.; Winckler, G. et al. (Hg.) (2000): Universitäten im Wettbewerb Zur Neustrukturierung österreichischer Universitäten. München.

Weber, W. (2003): Strategische Positionierung von Universitäten. In: Titscher, S.; Höllinger, S. (Hg.): Hochschulreform in Europa - konkret. Österreichs Universitäten auf dem Weg vom Gesetz zur Realität. Opladen, S. 91-104. 



\section{Steuerungsinstrumente für Hochschulen}

Hans-Ulrich Küpper

1 Hochschulreformen in der Bundesrepublik Deutschland

Vor dem Hintergrund des 1964 von Georg Picht ${ }^{1}$ ausgerufenen Bildungsnotstands löste die Studentenbewegung von 1968 eine tief greifende Reform des deutschen Hochschulsystems aus. Unter dem Motto der „Demokratisierung" mündete sie in die Gruppenuniversität. Während sich diese Reform im Rampenlicht der Öffentlichkeit vollzog, wurden die Veränderungen des Hochschulsystems nach 1990 zuerst kaum wahrgenommen. ${ }^{2}$ Angesichts des immer noch nicht bewältigten "Studentenbergs" rückte das Ziel der Effizenzsteigerung in den Vordergrund. Dadurch erhielten betriebswirtschaftliche Konzepte und Instrumente ein bis dahin nicht gekanntes Gewicht für die Hochschulen. Neue Hochschulgesetze in den Bundesländern, die fast im Wettbewerb entstanden und zum Teil nach wenigen Jahren erneut weitergeführt wurden, ${ }^{3}$ schraubten die Macht der Gremien und der Gruppen zurück. Ohne dass es zu großen Widerständen kam, wurden wichtige Elemente aufgehoben. Inzwischen haben die Veränderungen ein Ausmaß erreicht, die es gerechtfertigt erscheinen lassen, sie als die zweite große Hochschulreform der Bundesrepublik Deutschland zu bezeichnen. Da sich diese über einen längeren Zeitraum hinweg vollzog, kann sie (symbolisch) mit der Jahrtausendwende verknüpft und als effizienzorientierte Hochschulreform 2000 bezeichnet werden.

In ihr spielt der Übergang auf moderne Steuerungsinstrumente eine zentrale Rolle. Wesentliche Gründe hierfür liegen in den in Abschnitt 2 skizzierten Problemen, denen sich das deutsche Hochschulsystem durch die dramatische Ausweitung seiner Studentenzahlen seit 1970 ausgesetzt sah.

\footnotetext{
${ }^{1}$ Picht 1964.

${ }^{2}$ Vgl. Küpper 1997, Küpper 1998 a, Harnier u. a. 1998, S. 42.

${ }^{3}$ Beispielsweise gab es in Bayern 1998 und 2006 jeweils ein neues Hochschulgesetz.
} 
Aufgrund dieser Probleme wurde Effizienzsteigerung zu einem wichtigen Ziel für die nach 1995 begonnene Hochschulreform. In ihr wird den Hochschulen vom Staat deutlich mehr Autonomie eingeräumt. Damit gewinnt deren Steuerung ein besonderes Gewicht. Man benötigt leistungsfähige Steuerungsinstrumente auf zwei Ebenen. Zum einen liegt sie in der Beziehung zwischen den Landesregierungen sowie zuständigen Ministerien und den Hochschulen. Für diese in Abschnitt 3 behandelte Ebene ist der vermehrte Übergang auf Systeme zur Koordination und Steuerung dezentraler Einheiten wie die outputbezogene Budgetierung und Zielvereinbarungen charakteristisch. Die andere Ebene betrifft das Verhältnis zwischen Hochschulleitungen, Fakultäten und den darunter liegenden Einheiten wie Departments. In Abschnitt 4 wird aufgezeigt, durch welche Instrumente die Steuerungsprobleme innerhalb der Hochschulen besser bewältigt werden können. Dabei wird deutlich, dass eine Anpassung dieser Instrumente an die spezifischen Bedingungen und Ziele von Hochschulen notwendig ist. Dies mündet in die im letzten Abschnitt 5 aufgestellte These, dass es nicht um eine "Ökonomisierung“ oder "Amerikanisierung“ der Hochschulen gehen kann. Vielmehr muss auf Grundlage der deutschen, mit dem Namen Humboldt verbundenen Tradition ein angemessener Einsatz moderner Steuerungsinstrumente gefunden werden.

\section{Auslöser und Ziele der Hochschulreform 2000}

\subsection{Probleme des deutschen Hochschulsystems}

Den Hintergrund für die im vergangenen Jahrzehnt vollzogene Hochschulreform bilden einerseits interne Mängel des Hochschulsystems, die mit den Jahren immer deutlicher und bedrängender geworden sind. Zum anderen sind es externe Faktoren, durch die neue Anforderungen an die Hochschulen gestellt wurden. Zu Letzteren gehören insbesondere die durch die Wiedervereinigung ausgelösten Aufgaben, die Hochschulen in den neuen Bundesländern innerhalb kürzester Zeit wieder funktionsfähig zu machen und deren gesamtes System auf die veränderten Bedingungen auszurichten. Darüber hinaus hat die vor allem durch den Zusammenbruch des Kommunismus und die technologischen Entwicklungen vorangetriebene Globalisierung die Hoch- 
schulen in viel stärkerem Maße dem internationalen Wettbewerb ausgesetzt.

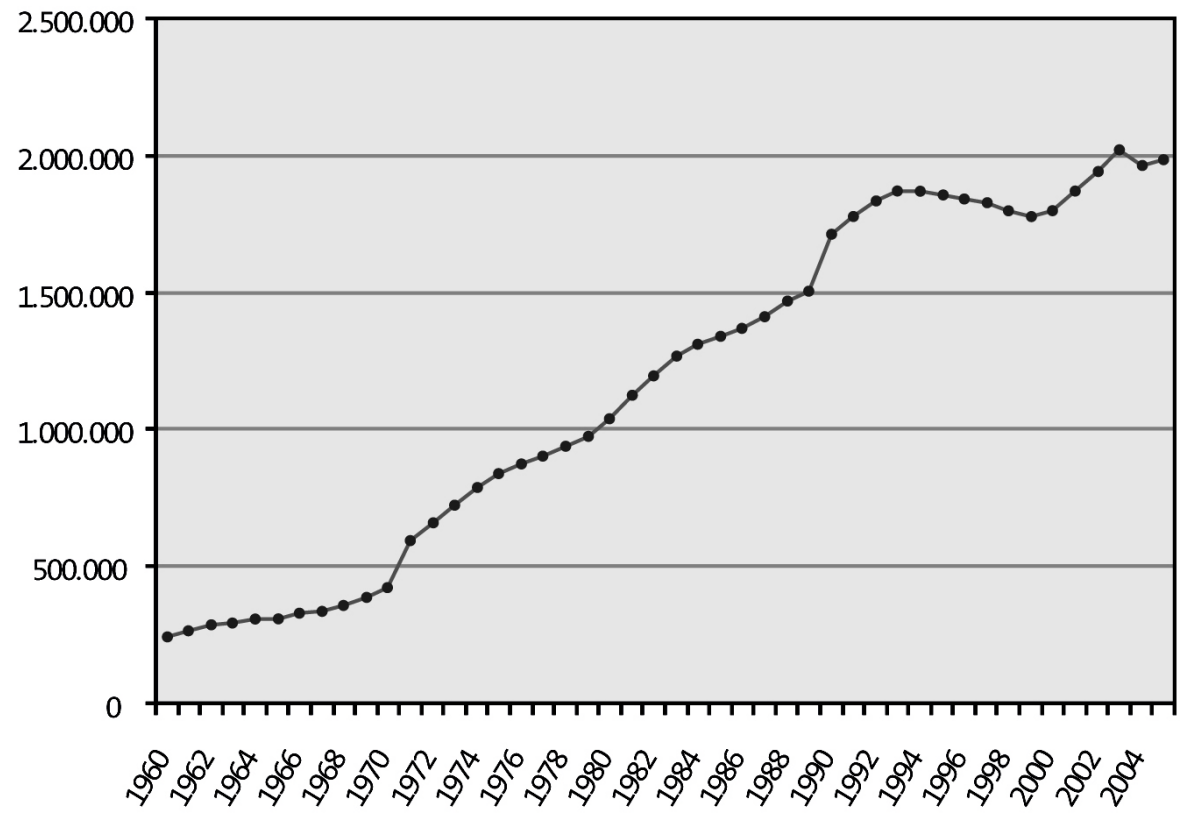

Abbildung 1: Entwicklung der Studentenzahlen in Deutschland (Quelle: Statist. Bundesamt [Hg.]: Bildung im Zahlenspiegel 2002; Statist. Bundesamt, Fachserie 11 R 4.3.1, 2003 und 2006/2007)

Diese erhöhten Anforderungen der Gesellschaft trafen auf ein Hochschulsystem mit gravierenden Mängeln. Es war und ist deutlich überlastet, weil wie von Georg Picht gefordert - die Studentenzahlen gemäß Abbildung 1 in zwei Jahrzehnten auf mehr als das Dreifache stiegen, die finanzielle Ausstattung der Hochschulen aber weit geringer war. ${ }^{4}$ Deshalb müssen insbesondere die Universitäten in vielen Fächern wie der Betriebswirtschaftslehre (BWL) einen Massenbetrieb bewältigen. Obwohl in der Reform nach

\footnotetext{
${ }^{4}$ Vgl. Kultusministerkonferenz (KMK) 2008, S. 149; so nahmen die Ausgaben der Hochschulen für Lehre und Forschung ohne die Hochschulkliniken und die Fächergruppe Humanmedizin zwischen 1980 und 1990 nominal um ca. 55 \%, real um nicht ganz 20 \% zu; vgl. Wissenschaftsrat 2002, S. 59.
} 
1968 das „Kleingruppenkonzept“ empfohlen wurde, hat man als Betriebswirt im Grundstudium praktisch nichts anderes erlebt und weiß, welchen Anspruch (insbesondere Anfänger-)Veranstaltungen mit bis zu 1000 Hörern im Hinblick auf die Vorlesung, die sie begleitenden Übungen und die zu korrigierenden Klausuren mit sich bringen. Betroffen davon sind primär die Universitäten, weil die Lenkung der Studentenströme in Deutschland äußerst problematisch erfolgt, indem entsprechend Abbildung 2 nur circa 30 Prozent eines Jahrgangs auf die Fachhochschulen gehen. Es ist Indiz einer derartigen Fehllenkung, wenn man „eben“ zur Universität gehen muss, weil an Berufsakademien (wie in Baden-Württemberg) sowie Fachhochschulen ein strengerer NC (Numerus Clausus) herrscht und allein die Universitäten räumlich sowie personell zur Bewältigung von Massen in der Lage sind.

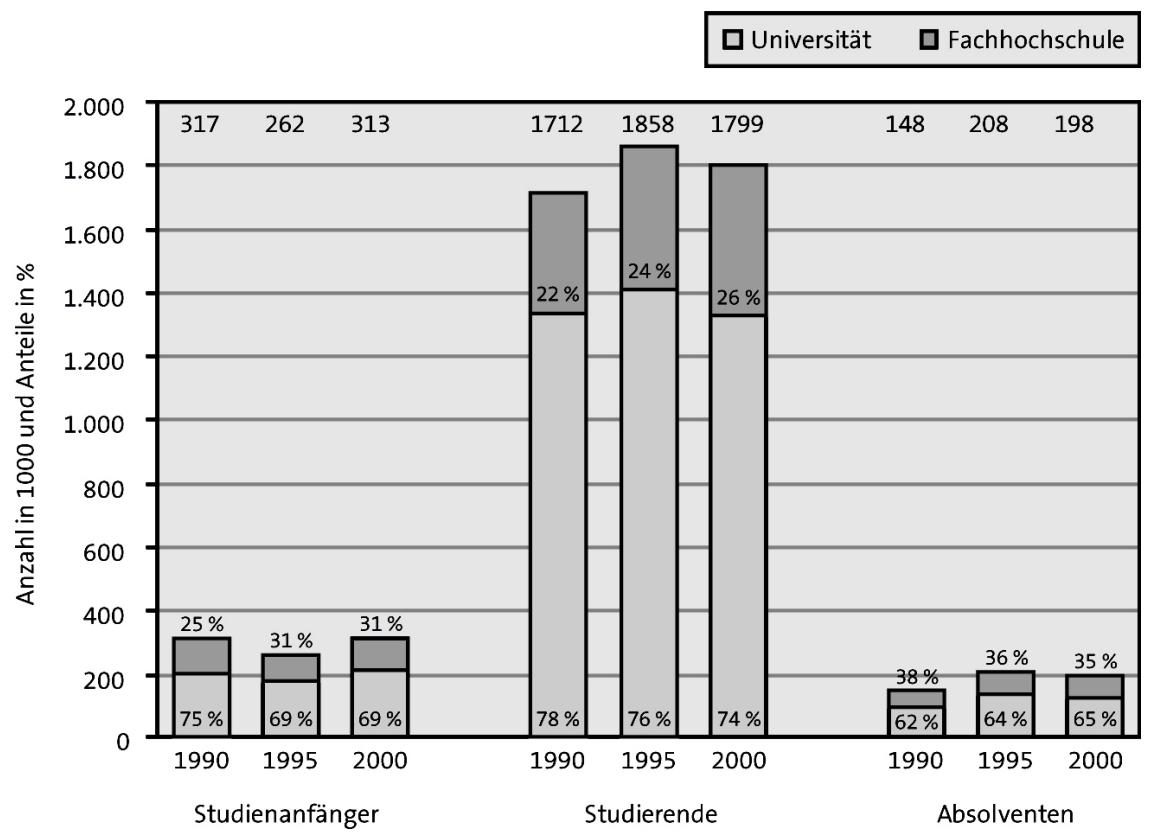

Abbildung 2: Verteilung von Studierenden auf Universitäten und Fachhochschulen in Deutschland von 1990 bis 2000 (Quelle: Bundesministerium für Bildung und Forschung, Grund- und Strukturdaten 2000/2001, S. 159 f.) 
Der zu bewältigenden Studentenzahlen versuchte man mit einem Kapazitätsrecht und einer zentralen Verteilung der Studierenden Herr zu werden. Verbunden mit einer zum Teil detailgenauen Steuerung durch die Landesministerien sowie Landesparlamente wies das Gesamtsystem ein überaus hohes $\mathrm{Maß}$ an Regulierung auf. Einen besonderen Ausdruck fand die schwierige Lage in einer Aussage des Bundesverfassungsgerichts von 1973, niedrige Betreuungsrelationen zwischen Studierenden und Professoren an Universitäten seien Ausdruck einer „unzulässigen Niveaupflege“. Zahlreiche Klagen unter anderem für den Zugang in zulassungsbeschränkte Fächer verschärften die Bürokratisierung und Regulierung, so dass zum Beispiel Prüfungsordnungen weniger der Information der Studierenden als der Absicherung gegen Rechtsverfahren dienen.

\subsection{Ziele der Hochschulreform 2000}

Auch wenn die in den 1990er-Jahren einsetzenden Änderungen im Hochschulsystem keinem einheitlichen Konzept folgen, lassen sich implizit zumindest drei Ziele erkennen, die mit ihnen erreicht werden sollen: eine Steigerung der Leistungs- und Wettbewerbsfähigkeit der Hochschulen, die Verstärkung des Wettbewerbs und die Dezentralisierung ihrer Steuerungssysteme. Die Erweiterung sowie Stärkung der europäischen Gemeinschaft nach 1990 und die Globalisierung haben in der Gesellschaft das Bewusstsein geweckt, wie wichtig die Hochschulen für die künftige Stellung eines Landes sind. Damit sind ihre Anforderungen an die Hochschulen deutlich gestiegen.

Von diesen werden nicht nur eine Steigerung der Effizienz zur bestmöglichen Nutzung der bereitgestellten Ressourcen und Finanzmittel verlangt. Ihre Studiengänge sollen internationalen Ansprüchen genügen, so dass die Absolventen gegenüber den wichtigsten anderen Ländern konkurrenzfähig sind. In der Forschung sollen zumindest die besten Universitäten den Anschluss an die internationale Spitzenforschung halten. Am deutlichsten sichtbar wurde dieser Anspruch, als nach Jahren eines kritischen Umgangs mit dem Begriff Leistungsorientierung ein sozialdemokratischer Bundeskanzler Anfang 2004 die Einrichtung einer „Elite“-Universität forderte.

Statt auf eine zentrale Regulierung wird zunehmend auf Elemente des Wettbewerbs gesetzt. Das zeigt sich unter anderem an den Bestrebungen zur 
Abschaffung des Hochschulrahmengesetzes und der zentralen Verteilung von Studienplätzen, der Einführung von Studiengebühren beziehungsweise Studienbeiträgen und der Exzellenzinitiative. Es wird auch deutlich an den vielfältigen Rankings von Hochschulen beziehungsweise deren Fächern, wie sie seit Jahren nicht nur vom Centrum für Hochschulentwicklung (CHE), sondern auch von renommierten privatwirtschaftlichen Magazinen ermittelt werden, was auf ihre Beachtung in der Gesellschaft hinweist.

Dem entspricht eine zunehmende Dezentralisierung und Differenzierung des Hochschulsystems. Eine stärkere Autonomisierung der Hochschulen wird nicht nur von den Hochschulen, deren Präsidenten und Professoren gefordert. Sie hat auch immer mehr Eingang in politische Forderungen und Hochschulgesetze gefunden, wofür die Einrichtung von Hochschulräten und die Übertragung des Berufungsrechts auf die Hochschulen sichtbare Beispiele bilden. Obwohl viele Hochschullehrer es kaum glauben wollen, stellt die Autonomie auch für viele Ministerien und deren Beamte ein Reformziel dar.

Ein wichtiges Instrument zur Erreichung dieser grundlegenden Ziele wird im Rahmen der Hochschulreform 2000 in der Nutzung betriebswirtschaftlicher Führungs- und Steuerungsinstrumente gesehen. Man erkannte, dass eine Übertragung von Autonomie nur sinnvoll ist, wenn die Hochschulen über die notwendigen Instrumente und Kenntnisse verfügen. Die Abkehr von einer vielfach tief gehenden Steuerung durch Ministerien und Parlamente setzt voraus, an Stelle der bisherigen Regulierungssysteme Verfahren zur Koordination und Lenkung der Hochschulen einzuführen, da diese weiterhin in hohem Maße vom Staat finanziert werden. Teilweise wurde dabei von Politikern und Ministerien die Auffassung vertreten, Hochschulen könnten umso mehr Autonomie erhalten, je mehr sie die ökonomischen Instrumente erwerbswirtschaftlicher Unternehmungen übernehmen. Der Glaube an deren Zweckmäßigkeit fand einen besonders extremen Ausdruck im Modellversuch eines SPD-geführten Bundeslandes, bei dem drei seiner Hochschulen die Rechnungslegung des Handelsgesetzbuchs (HGB) übernahmen, obwohl gleichzeitig die SPD-Bundesbildungsministerin die Einführung von Studiengebühren verbieten wollte.

Die Steuerung der Hochschulen betrifft vor allem zwei Ebenen. Zum einen bezieht sie sich auf das Verhältnis zwischen den Bundesländern und den Hochschulen, von denen die ganz überwiegende Zahl staatlich ist und die zu einem wesentlichen Teil vom Staat finanziert werden. Zum anderen betrifft sie das Führungssystem innerhalb der einzelnen Hochschule. Grundlage 
für eine zielorientierte und effiziente Steuerung sind auf beiden Ebenen aussagefähige Informationssysteme. Diese bilden die Grundlage für den Einsatz von Koordinations- und Steuerungskonzepten, wie sie insbesondere im Controlling entwickelt und analysiert werden, sowie die Nutzung spezifischer Führungsteilsysteme in den Hochschulen.

\section{Steuerung des Hochschulsystems}

\subsection{Dezentralisierung der Steuerung}

Da es in Deutschland relativ wenige Privathochschulen gibt, hat der Staat nicht nur als Gesetzgeber, der das Bildungssystem zu regulieren hat, sondern auch als Eigentümer der meisten Hochschulen einen großen Einfluss auf das Hochschulsystem. Eine Besonderheit gegenüber anderen Staaten besteht darin, dass die Kulturhoheit bei den 16 Bundesländern liegt. Daraus entsteht ein Wettbewerb, wie er zum Beispiel im Hinblick auf die Reformierung der Hochschulen durch neue Landesgesetze und in der Exzellenzinitiative sichtbar geworden ist. Ein grundsätzliches Merkmal der Hochschulreform 2000 liegt darin, dass man entsprechend Abbildung 3 von einer eher zentralisierten zu einer stärker dezentralisierten Steuerung der Hochschulen mit marktwirtschaftlichen Elementen gelangen möchte.

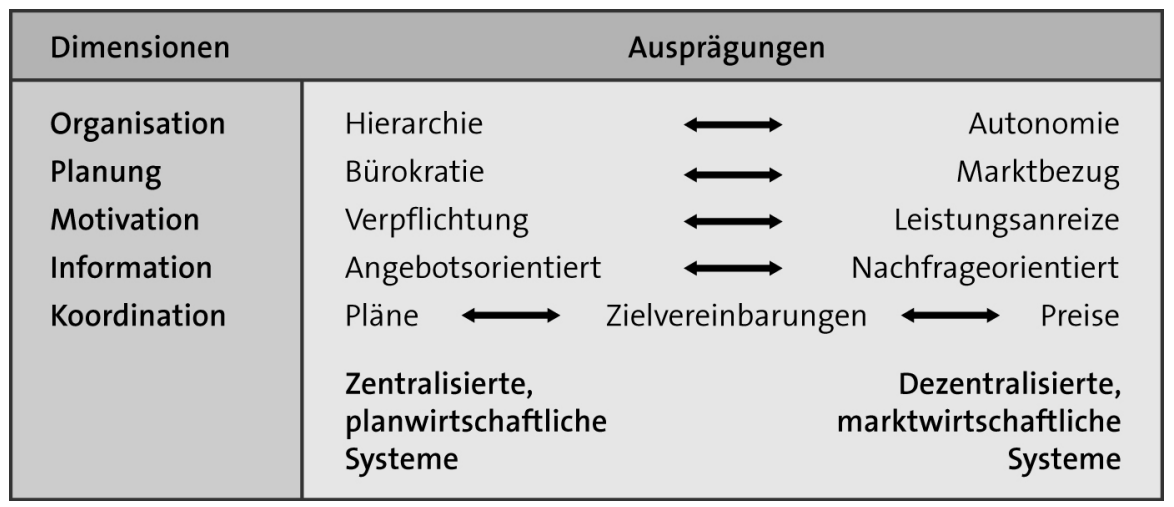

Abbildung 3: Dimensionen von Steuerungssystemen 


\subsection{Regelung des Studiensystems}

In jedem Land hat der Gesetzgeber die Aufgabe, Regelungen für die grundsätzliche Struktur des Studiensystems vorzugeben. Die Hochschulgesetze aller Bundesländer enthalten dementsprechend Vorschriften insbesondere zu möglichen Studiengängen, den in ihnen abzulegenden Prüfungen und staatlich anerkannten Abschlüssen. Das Bestreben, Kompetenzen der Ministerien abzugeben, zeigt sich in diesem Bereich vor allem in dem Übergang auf ein Akkreditierungssystem. Bis in die 90er-Jahre hinein mussten Prüfungs- und Studienordnungen nicht nur von den zuständigen Ministerien genehmigt werden. Diese übernahmen darüber hinaus eine eingehende Prüfung der von den Hochschulen ausgearbeiteten (und dort schon auf ihre rechtliche Zulässigkeit geprüften) Ordnungen. Dabei orientierte man sich an zum Beispiel an Allgemeinen Bestimmungen für Diplomprüfungsordnungen und Rahmenprüfungsordnungen, wie sie für verschiedene Fächer ausgearbeitet worden waren. Darin lag ein zentralisierendes Element, das zu einer Vereinheitlichung des Studiums an den Universitäten beziehungsweise Fachhochschulen beitrug. Die Übertragung der fachlichen Prüfung auf (unterschiedliche) Akkreditierungsagenturen, in denen auch Vertreter der Wirtschaft und Gesellschaft sitzen, dürfte $\mathrm{zu}$ einer wesentlich stärkeren Differenzierung der Studiengänge führen. Zudem hat sich die Prozess-Akkreditierung einzelner Studiengänge als sehr zeit- und kostenintensiv erwiesen. Deshalb besteht eine Tendenz, zu einer System-Akkreditierung zu gelangen, in deren Mittelpunkt das Qualitätssicherungssystem der Hochschule und nicht mehr der einzelne Studiengang steht. Wegen der unterschiedlichen Auffassungen auch der Bundesländer ist gegenwärtig nicht klar ersichtlich, welche Form sich letztlich durchsetzen wird.

Einen wesentlich größeren Einfluss auf das Studium hat der BolognaProzess. Auch wenn das Diplom in Deutschland - und zumindest teilweise (zum Beispiel für Ingenieure) im Ausland - sowie bei vielen Politikern ${ }^{5}$ eine hohe Anerkennung genoss, unterzeichnete der Vertreter der Bundesrepublik 1999 die gemeinsame Erklärung der Europäischen Bildungsminister zur Struktur des europäischen Hochschulraums in Bologna. Erst im darauffolgenden Jahrzehnt wurde deutlich, dass alle Bundesländer in den meis-

\footnotetext{
${ }^{5}$ Beispielsweise bei dem (von 1986) bis 2003 für Bayern zuständigen Wissenschaftsminister Hans Zehetmair.
} 
ten Studiengängen deshalb das Diplom aufgeben und auf ein gestuftes System mit Bachelor und Master übergehen (müssen). ${ }^{6}$ Dies führt in ihnen zu einer grundsätzlichen Analyse sowie Neugestaltung des Studiums, wodurch die Differenzierung des Studiensystems weiter zunehmen dürfte.

Deutliche Auswirkungen auf das Studiensystem hat die Abkehr von einer zentralen Verteilung knapper Studienplätze. An die Stelle dieses zentralistischen planwirtschaftlichen Systems tritt in vielen Fächern eine dezentrale Auswahl durch die einzelne Hochschule. Neben den in - inzwischen nicht mehr bundeseinheitlichen, sondern länderspezifischen - Kapazitätsverordnungen festgelegten Regeln für die Auswahl von Studierenden in Studiengängen mit einem NC können die Hochschulen zudem Eignungsfeststellungsverfahren ${ }^{7}$ einrichten. Damit gewinnt die Auswahl der Studierenden für jede Fakultät eine zentrale Bedeutung. Wie Erfahrungen im Ausland zeigen, bildet dieser Zugang einen wichtigen Parameter für die Ausrichtung einer Fakultät, durch den die Differenzierung der Hochschulen gefördert wird. Auf dessen Gewicht weisen schon die ersten Erfahrungen der Universitäten hin. Wie Abbildung 4 dokumentiert, haben sich beispielsweise an den Universitäten München und Tübingen durch die dezentrale Auswahl verbunden mit dem Übergang auf ein Bachelorstudium der Anteil an Studienanfängern mit einem besseren Abiturnotenschnitt und die Leistungsergebnisse deutlich erhöht. Attraktive Fakultäten und Hochschulen erhalten dadurch die Möglichkeit, die für sie geeigneten Studierenden auszusuchen.

Diese Veränderung in der Verteilung der Studentenströme dürfte auch durch die nach einem Urteil des Bundesverfassungsgerichts ${ }^{8}$ möglich gewordene und von mehreren Bundesländern eingeführten Studiengebühren verstärkt werden. Werden diese Mittel wie geplant zur Verbesserung der Studienbedingungen genutzt, könnten derartige "Studienbeiträge“ die Attraktivität sogar erhöhen. Um positive Wirkungen eines solchen Systems zu nutzen, ${ }^{9}$ erscheint es jedoch notwendig, dass es einerseits zu einer (echten) Differenzierung ihrer Höhe kommt und andererseits das Stipendiensystem ausgeweitet wird, damit nicht soziale Faktoren die Studienplatzwahl (zu stark) beeinflussen.

\footnotetext{
${ }^{6}$ Vgl. Gensch/Schindler 2003; Kehm/Teichler 2005; Kehm/Teichler 2006; Witte 2006 a und b.

${ }^{7}$ Vgl. z. B. Art. 44 des Bayrisches Hochschulgesetz (BayHSchG) 2006

${ }^{8}$ Urteil des Bundesverfassungsgerichts vom 26. Januar 2005.

${ }^{9}$ Vgl. auch Küpper 2002 b.
} 


\begin{tabular}{|c|c|c|c|}
\hline \multicolumn{4}{|c|}{ Zulassung zum BWL-BA-Studium an der Universität München } \\
\hline Abiturnote & $1,0-1,5$ & $1,0-2,0$ & $1,0-2,5$ \\
\hline Jahrgang 2005 & $10 \%$ & $33 \%$ & $65 \%$ \\
\hline Jahrgang 2006 & $16 \%$ & $70 \%$ & $90 \%$ \\
\hline Jahrgang 2007 & $21 \%$ & $84 \%$ & $88 \%$ \\
\hline \multicolumn{4}{|c|}{ Ergebnisse aus BWL-Grundstudium Universität Tübingen } \\
\hline & $\begin{array}{l}\text { Gesamtes Pflicht- } \\
\text { programm }\end{array}$ & Durchfallquote & Durchschnittsnote \\
\hline Jahrgang 2003 & $43 \%$ & $24 \%$ & 3,1 \\
\hline Jahrgang 2004 & $46 \%$ & $21 \%$ & 3,2 \\
\hline Jahrgang 2005 & $58 \%$ & $20 \%$ & 2,8 \\
\hline Jahrgang 2006 & $77 \%$ & $12 \%$ & 2,7 \\
\hline
\end{tabular}

Abbildung 4: Auswirkungen des Übergangs Auswahl der Studierenden und Bachelor

Damit die Hochschulen und die Studienbewerber diese für beide zentral wichtige Entscheidung fundiert treffen können, müssen sie über die erforderlichen Informationen verfügen. Deshalb wird die Bedeutung von Informationsinstrumenten eher zunehmen. Zusammen mit einer Vielzahl von Einzeluntersuchungen lassen sich aus ihnen Erkenntnisse über relevante Merkmale von Hochschulen und Fakultäten gewinnen. Während es schon bisher eine Vielzahl von Informationen über das Studium gab, wird das Defizit in Bezug auf den Weg nach dem Studium in Deutschland erst langsam beseitigt. Zwar führt Hochschulinformations-System GmbH (HIS) seit Langem bundesweite Absolventenstudien durch; ${ }^{10}$ diese erlauben jedoch keine Rückschlüsse auf die einzelnen Hochschulen. Dem wirken tiefer gehende Absolventenstudien entgegen, wie sie zunehmend in den Bundesländern und Hochschulen vorgenommen werden. Das 2005 gestartete Bayerische Absolventenpanel $B A P^{11}$ erfasst in einer Vollerhebung zuerst die Studierenden in den wichtigsten Studiengängen an allen Bayerischen Universitäten und Fachhochschulen circa anderthalb Jahre nach ihrem Abschluss. Die ersten beiden Erhebungen der Absolventenjahrgänge 2003/4 und 2005/6 wurden für ganz Bayern und für jede einzelne Hochschule ausgewertet. ${ }^{12}$ Das Panel wird fünf und zehn Jahre nach dem Abschluss erneut befragt, um Infor-

\footnotetext{
${ }^{10}$ Vgl. Minks/Briedis 2005; Kerst/Schramm 2008.

${ }^{11}$ Vgl. Falk/Reimer/Hartwig 2007.
} 
mationen über die weitere berufliche Entwicklung zu erhalten. Die erste derartige erneute Befragung ist für 2010 geplant.

\subsection{Verteilung der staatlichen Ressourcen und Finanzmittel}

An den staatlichen Hochschulen bildet die Verteilung der Ressourcen und Finanzmittel ein wichtiges Instrument zur Steuerung der Hochschulen. Besonders in diesem Bereich zeigt sich der Übergang auf stärker dezentralisierte Koordinations- und Steuerungssysteme. Seit den ersten Schritten der Hochschulreform 2000 werden Globalhaushalte für die einzelnen Hochschulen diskutiert und zunehmend umgesetzt. ${ }^{13}$ Damit erhalten diese eine eigene finanzielle Autonomie.

Gleichzeitig wurden verschiedene Verfahren zur Verteilung der Mittel auf die Hochschulen diskutiert und in unterschiedlicher Weise in den Ländern umgesetzt. Dabei scheint sich die Gliederung in eine Grundversorgung, einen kennzahlenbasierten und einen verhandlungsbasierten Teil herauszuschälen. Ersterer umfasst insbesondere die einer Hochschule zugewiesenen Stellen oder orientiert sich an diesen. Der zweite Block wird mit Bedarfsund Leistungsgrößen wie der Zahl an Studierenden und/oder Absolventen, Promotionen und Habilitationen, eingeworbenen Drittmitteln, der Frauenquote, dem Anteil an Ausländern und Ähnlichem verknüpft. Von ihm sollen unmittelbar Leistungsanreize ausgehen. Als drittes, zunehmend wichtiges Instrument werden Zielvereinbarungen getroffen, durch welche die Hochschulen für einen Zeitraum Planungssicherheit erhalten sollen. In ihnen werden konkrete Ziele zum Beispiel im Hinblick auf Studiengänge, Studentenzahlen, Innovationen und so weiter festgelegt.

An dieser Entwicklung erkennt man, dass auch im Hochschulbereich mit Verfahren der outputbezogenen Budgetierung sowie Kennzahlen- und Zielsystemen neuere Ansätze des Controlling genutzt werden. ${ }^{14}$ Die politischen Ziele eines Bundeslandes und die Machtverhältnisse zwischen seinen politisch relevanten Gruppen sowie zwischen Wissenschafts- und Finanzministerium schlagen sich in der konkreten Ausprägung des jeweiligen

\footnotetext{
${ }^{12}$ Vgl. Falk/Reimer 2007; Reimer 2008; http://www.ihf.bayern.de/?BAP\%3A_Das_Bayerische_Absolventenpanel:Ergebnisse.

${ }^{13}$ Vgl. Krasny/Ziegele 1997.

${ }^{14}$ Vgl. hierzu Küpper 2008, S. 360 ff. und S. 389 ff.
} 
Verteilungssystems, dem Gewicht der verschiedenen Parameter und der Präzision sowie Bindung der Zielvereinbarungen nieder. Erkennbar ist aber durchweg, dass man auf ein wesentlich breiteres sowie stärker leistungsorientiertes Instrumentarium übergeht, als es die weitgehende Verankerung in einem gegebenenfalls zweijährigen Landeshaushalt bedeutete.

In dem Zeitraum zwischen 2006 und 2020 sieht sich Deutschland erneut mit einer Ausweitung der Studienbewerber konfrontiert. Die Prognosen besagen, dass die Gesamtzahl der Studierenden bis circa 2014 um zwischen 20 und 30 Prozent zunehmen und bis zum Ende dieses Jahrzehnts auf dem dann erreichten Niveau verbleiben wird. Dazu kommt, dass in einer Reihe von Bundesländern wegen des Übergangs auf ein achtjähriges Gymnasium in einzelnen, aber unterschiedlichen Jahren zwei Abiturjahrgänge an die Hochschulen drängen. Um dem zu begegnen, hat die Bundesregierung zuerst für vier Jahre mit den Ländern einen „Hochschulpakt" geschlossen, der durch eigene Programme der einzelnen Länder ergänzt wird. So wird beispielsweise in Bayern den Hochschulen für die Jahre 2008 bis 2013 eine zusätzliche Milliarde Euro zur Einrichtung von Personalstellen und weitere Mittel zur Schaffung der erforderlichen Raumkapazitäten bereitgestellt. Verbunden mit einem breiten Katalog von Einzelmaßnahmen unter anderem wie der vorgezogenen Wiederbesetzung von Professuren und der Gewinnung von Seniorprofessoren sollen die Studienkapazitäten entsprechend ausgeweitet werden.

Während dieses Programm auf das Studium gerichtet ist, erhält die Forschung Anreize durch das Exzellenzprogramm. Die Wirkungen des ersten Programms dieser Art lassen erkennen, dass mit ihm der Wettbewerb zwischen den Universitäten im Forschungsbereich beflügelt wird. Auch die Auszeichnung einzelner „Eliteuniversitäten“ trägt zur Differenzierung zwischen den Hochschulen bei.

4 Steuerung der einzelnen Hochschulen

\subsection{Ausbau des Führungssystems}

In der Hochschulreform 2000 werden vielfältige Entscheidungsrechte an die Hochschulen übertragen. Dies verlangt auf der anderen Seite, dass diese 
über die notwendigen Kompetenzen und Instrumente verfügen. Während in der Reform nach 1968 Organisationsfragen im Mittelpunkt standen, erstreckt sich die Hochschulreform 2000 auf das gesamte Führungssystem. ${ }^{15}$ Entsprechend Abbildung 5 werden mit ihm über den Einsatz der Ressourcen und Potenziale die Geschäftsprozesse einer Hochschule. ${ }^{16}$ gesteuert. Seine Komponenten sind Organisation und Personalführung, Planung und Kontrolle, das Informations- sowie das koordinierende Controllingsystem. ${ }^{17}$

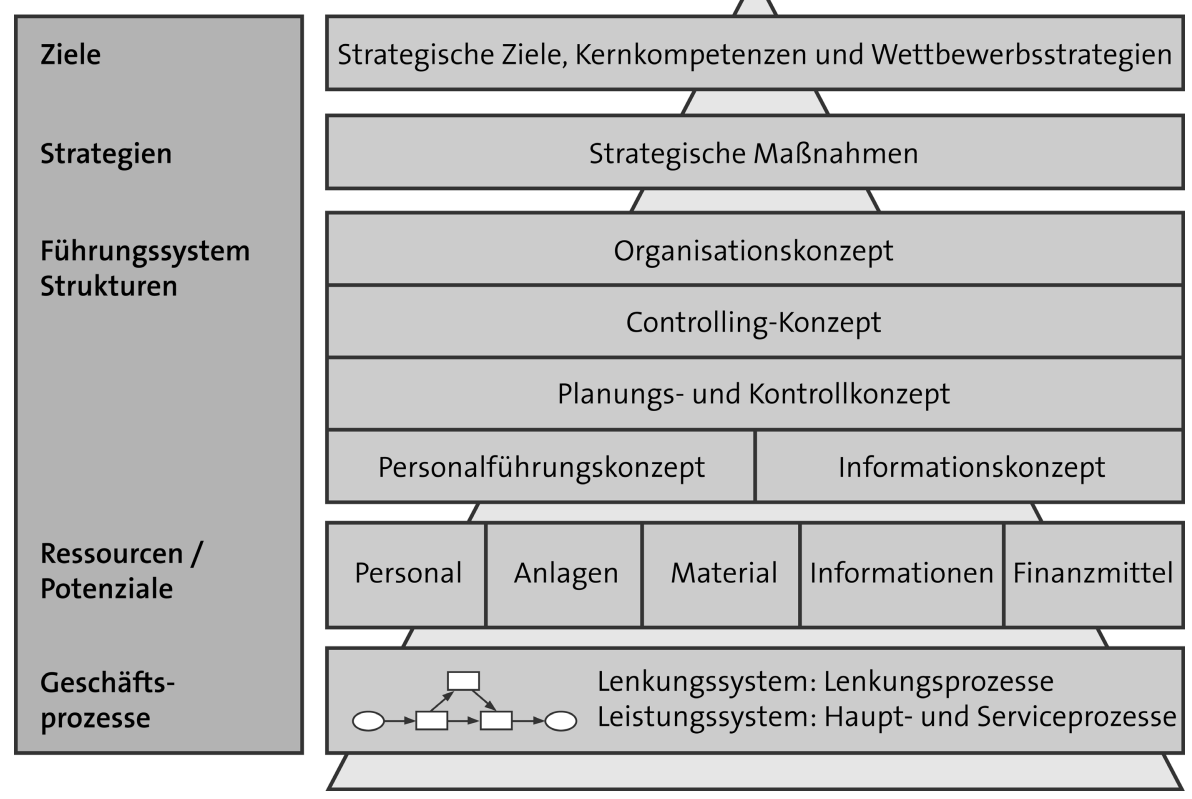

Abbildung 5: Strukturmodell von Hochschulen

\footnotetext{
${ }^{15}$ Vgl. Küpper/Sinz 1998.

${ }^{16}$ Vgl. Sinz 1998, S. 5; Küpper 2008, S. 518 f.

${ }^{17}$ Vgl. Küpper 2008, S. 28 ff.
} 


\subsection{Organisation und Personalführung}

Zwar wird Organisationsfragen nicht dasselbe Gewicht wie in der Reform nach 1968 beigemessen, dennoch spielen sie wieder eine Rolle. Verschiedene neue Hochschulgesetze der Bundesländer haben die Macht der Hochschulleitungen und ihrer Präsidenten sowie der Dekane deutlich gestärkt. ${ }^{18}$ Dahinter steht möglicherweise die Überlegung, dass in einem Bereich, in dem die Freiheit von Forschung und Lehre grundgesetzlich gesichert ist, Reformen lediglich von starken Führungsorganen durchgesetzt werden können. Viele Hochschulen sehen es auch als erforderlich an, die Organisationsstrukturen zu straffen und gehen daher auf weniger und größere Fakultäten beziehungsweise Fachbereiche über. Auf der darunter liegenden Ebene wird häufig versucht, leistungsfähige Einrichtungen wie Departments zu schaffen, welche über bisherige Lehrstuhlgrenzen hinausgehen. Zudem gibt es Überlegungen wie in dem Konzept "Wissenschaftsland Bayern 2020 " ${ }^{19}$ hochschulübergreifende Einheiten zu bilden. Geht man diesen Schritt weiter, so ist es denkbar, die in einem Raum ansässigen Forschungsund Lehreinheiten beispielsweise in Natur- oder Ingenieurwissenschaften, Wirtschafts- und Rechts- oder Sozialwissenschaften und Ähnliches zu relativ selbstständigen Einheiten zusammenzufassen, über welchen die Gesamtleitung in Form einer Holding organisiert wird.

Mit der Übertragung von Autonomie auf die Hochschulen und dem Rückzug von Ministerien sowie Landesparlamenten aus der Detailsteuerung stellt sich das Problem, wie der Staat seine Funktion als Eigentümer wahrnimmt. Eine Antwort darauf wurde insbesondere durch die Einrichtung von Hochschulräten gesucht, in die Vertreter aus Wissenschaft, Gesellschaft und Wirtschaft ${ }^{20}$ berufen werden. Inwieweit diese an die Stelle von Ministerien und Parlamenten treten können, ist zumindest fraglich. Die Interessenwahrnehmung der Gesellschaft als Eigentümerin der staatlichen Hochschulen erscheint ein bisher noch nicht ausreichend analysiertes und ungelöstes Problem im Dezentralisierungsprozess der Hochschulreform 2000. Ferner wirft das Zusammenspiel zwischen hochschulinternen und

\footnotetext{
${ }^{18}$ Vgl. z. B. Art. 20, 21 und 28 Abs. 3 BayHSchG 2006.

${ }^{19}$ Wissenschaftsland 2005.

${ }^{20}$ Beispielsweise sind nach Art 26 BayHSchG 2006 neben des Vertretern des Senats ,,acht Persönlichkeiten aus Wissenschaft und Kultur sowie insbesondere Wirtschaft und beruflicher Praxis" zu bestellen.
} 
hochschulexternen Funktionsträgern sowie zwischen Hochschulleitung, Dekanen, Senat und Hochschulrat eine Reihe von Problemen auf.

Mit der Stärkung der Dekane verbindet sich die Frage, inwieweit auch die Leitung dieser dezentralen Lehr- und Forschungseinheiten neben der Stellvertretung durch den Prodekan einer Verbreiterung bedarf. Dem wird teilweise durch ihre Erweiterung um Forschungsdekane und Leitern von (Studenten- und/oder Prüfungs-)Serviceeinheiten begegnet.

Ein grundsätzliches Problem liegt im künftigen Verhältnis zwischen Hierarchie und Kollegialität innerhalb der Fakultäten und darüber hinausgehend der gesamten Hochschule. Durch die Freiheit von Forschung und Lehre sowie die Kompetenz der Professoren in ihrem jeweiligen Fach wird diese Frage anders als in Wirtschaftsunternehmungen zu lösen sein.

Die Wahrnehmung der gestiegenen Verantwortung erfordert eine stärkere Professionalisierung der Führungspersonen auf den relevanten Ebenen. Im Hinblick auf die Personalführung stellt sich zudem die Frage, wie die wissenschaftlichen Anreizsysteme für Professoren und Mitarbeiter auszubauen sind. ${ }^{21}$ Die mit dem Übergang auf die „W-Besoldung“ vorgenommenen Versuche, in die Belohnung der Professoren weitere Leistungskomponenten einzubauen, erscheinen gegenüber der Wirkung des Berufungsmarktes sekundär und stellen die Hochschulen vor Verteilungsprobleme, welche die Kollegialität belasten.

\subsection{Planung und Kontrolle}

Planung ${ }^{22}$ und Kontrolle waren an den Hochschulen und deren Fakultäten nicht grundsätzlich unbekannt. Immer wieder wurden Struktur- und Entwicklungspläne verabschiedet, in denen man zum Beispiel die künftige Ausrichtung der Studiengänge und Professuren sowie gemeinsame Forschungsfelder beschrieb. Deren Wirkungen blieben jedoch begrenzt.

Mit der Hochschulreform 2000 scheint dieses Führungsinstrument mehr Bedeutung zu gewinnen. Man erkennt eher, dass auch Hochschulen strategische Überlegungen anstellen müssen, wie es im Strukturmodell von Abbildung 5 verankert ist. Diese Planungsebene spielt für sie eine besondere Rolle, weil ein Großteil ihrer Entscheidungen zum Beispiel über Studien-

\footnotetext{
${ }^{21}$ Vgl. Küpper 1997, S. 131 ff.; Hartmann 1998, S. 47 ff. und S. 87 ff.

${ }^{22}$ Vgl. Küpper 1998 b.
} 
gänge, die Einrichtung und Besetzung von Fakultäten, Departments und Professuren sowie Forschungsschwerpunkten längerfristigen Charakter hat. Sie dienen der Schaffung von Ausbildungs- und Forschungspotenzialen.

Die Exzellenzinitiative hat dazu beigetragen, dass Profilbildung als strategische Aufgabe erkannt wurde. Aufbauend auf Stärken- und Schwächenanalysen können Hochschulen und deren Fakultäten Strategien dafür erarbeiten, wie sie sich in Studium und Lehre, Forschung sowie in ihren Serviceaktivitäten aufstellen. Die Notwendigkeit derartiger Überlegungen ist durch den zunehmenden Wettbewerb zwischen den Hochschulen und die Neuorientierung des Studiums im Übergang auf Bachelor- sowie konsekutive, nicht konsekutive und exekutive Masterstudiengänge noch deutlicher geworden. Dazu kommt die Nachwuchsförderung, in der die Einrichtung von postgradualen Forschungsstudiengängen, Graduiertenkollegs, der Übergang auf kumulierte Promotion sowie Habilitation und Juniorprofessoren strategische Weichenstellungen darstellen.

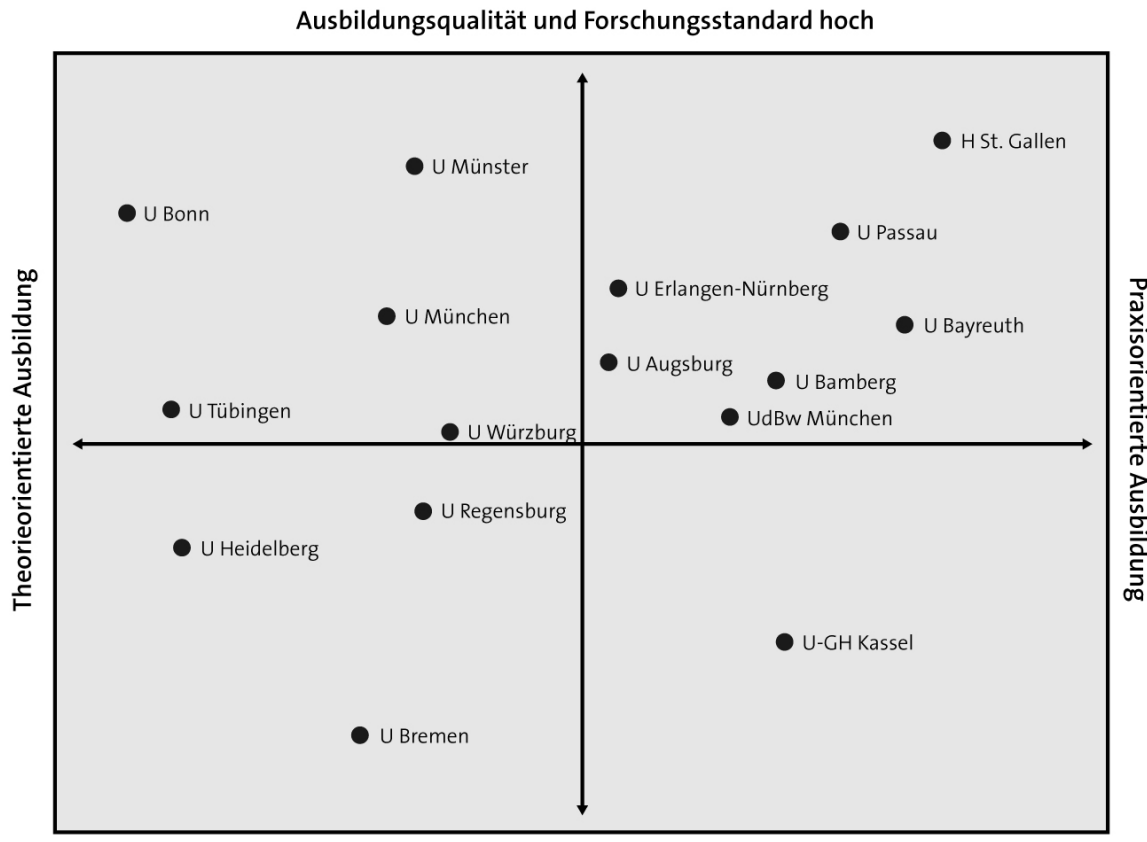

Ausbildungsqualität und Forschungsstandard niedrig

Abbildung 6: Darstellung der strategischen Positionierung einer Hochschule 
Zur Untermauerung der Entscheidungsfindung im strategischen Bereich lassen sich betriebswirtschaftliche Planungs- und Kontrollinstrumente auf Hochschulen übertragen. Dazu gehören SWOT-Analysen für die Herausarbeitung interner Stärken und Schwächen sowie die Früherkennung externer Chancen und Gefahren. Die Darstellung, Beurteilung und Festlegung von Strategien kann mit der Portfolio-Analyse plastisch untermauert werden. Für die gesamte Hochschule kann man auf diese Weise beispielsweise entsprechend Abbildung $6^{23}$ veranschaulichen, wo sie im Hinblick auf die Theorie- oder Praxisorientierung der Ausbildung und die Ausbildungsqualität sowie ihre Forschungsstandards steht.

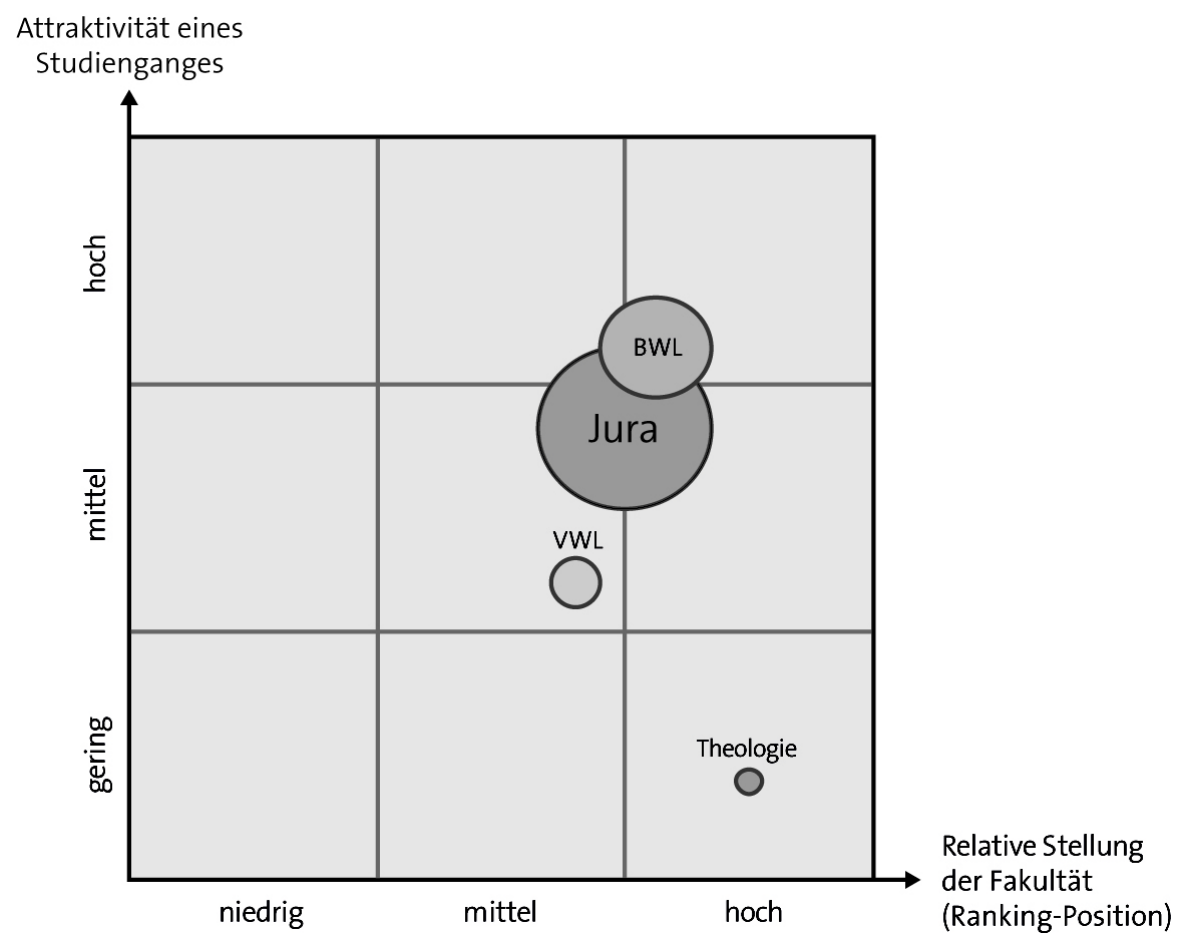

Abbildung 7: Einordnung von Studiengängen und Fakultäten in ein Portfolio

${ }^{23}$ Küpper 1998 b, S. 142. 
Das Portfolio-Instrumentarium lässt sich in vielfältiger Weise gestalten. So kann man zum Beispiel wie in Abbildung $7^{24}$ die (über Bewerberzahlen oder Ähnliches gemessene) Attraktivität von Studiengängen und die (über Rankings oder Ähnliches gemessene) Reputation der sie anbietenden Fakultäten einander gegenüberstellen, in der die Größe der Kreise die Zahl der Studienanfängerplätze, Studierenden oder Absolventen oder anderes wiedergeben kann. Die zweidimensionale Darstellung begrenzt zwar den Untersuchungsgegenstand, führt aber zu einer Veranschaulichung als Grundlage der Analyse. Mit ihr lassen sich Vergleiche plastisch untermauern, die Einbindung in Zusammenhänge und die Notwendigkeit zur strategischen Abstimmung aufzeigen.

\subsection{Informations- und Controllingsysteme}

Rationale Entscheidungen können nur auf der Basis ausreichender Informationen getroffen werden. Ein auffallendes Merkmal der sich vollziehenden Reform liegt darin, dass der lange bestehende Mangel an Informationen als Defizit empfunden wurde und man intensiv um dessen Behebung bemüht ist. Wie Abbildung 8 veranschaulicht, sollte eine Hochschule über leistungsfähige Informationssysteme auf Hochschul-, Fakultäts- und Studentenebene verfügen.

\begin{tabular}{|c|c|c|}
\hline & Informationsträger & $\begin{array}{l}\text { Informationsbedarf zur } \\
\text { Entscheidungsvorbereitung }\end{array}$ \\
\hline $\begin{array}{l}\text { Hochschul-Informations- } \\
\text { system }\end{array}$ & $\begin{array}{l}\text { - Rektor / Präsident } \\
\text { (Vizerektor/-präsident) } \\
\text { - Kanzler } \\
\text { - Professoren } \\
\text { - Wissenschaftliche Mitarbeiter } \\
\text { - Studentenvertreter } \\
\text { - Nicht wissenschaftliches Personal }\end{array}$ & $\begin{array}{l}\text { - Parlament / Versammlung } \\
\text { - Senat } \\
\text { - Kommissionen } \\
\text { - Ausschüsse }\end{array}$ \\
\hline $\begin{array}{l}\text { Fakultäts-Informations- } \\
\text { system }\end{array}$ & $\begin{array}{l}\text { - Professoren } \\
\text { - Wissenschaftliche Mitarbeiter } \\
\text { - Studentenvertreter } \\
\text { - Nicht wissenschaftliches Personal }\end{array}$ & $\begin{array}{l}\text { - Dekan / Dekanat } \\
\text { - Fachbereichsrat } \\
\text { - Ausschüsse } \\
\text { - Institute } \\
\text { - Lehrstühle }\end{array}$ \\
\hline $\begin{array}{l}\text { Studenten-Informations- } \\
\text { system }\end{array}$ & $\begin{array}{l}\text { - Studierende } \\
\text { - Studieninteressenten }\end{array}$ & \\
\hline
\end{tabular}

Abbildung 8: Ebenen für Informationssysteme in Hochschulen

\footnotetext{
${ }^{24}$ Küpper 1998 b, S. 143.
} 
Große Aufmerksamkeit genießen die in den Fakultäten angewandten Evaluationssysteme für Lehrveranstaltungen, was sich auch in ihrer Verankerung in Hochschulgesetzen ${ }^{25}$ niederschlägt. Eine Fakultät benötigt jedoch wesentlich mehr Informationen, wenn sie im Wettbewerb eine gute Position erreichen möchte. Abbildung 9 verdeutlicht, dass ein Fakultätsberichtssystem $^{26}$ quantitative und qualitative Daten zu Lehre und Forschung liefern sollte. Die Evaluation der einzelnen Lehrveranstaltung ist primär für den jeweiligen Dozenten wertvoll und kann von diesem für Verbesserungen genutzt werden. Demgegenüber hat sich gezeigt, dass sich Probleme im Lehr- und Prüfungsbetrieb vor allem durch eine umfassende Befragung der Studierenden und Dozenten beziehungsweise durch Zufriedenheitsstudien ${ }^{27}$ in Erfahrung bringen lassen. Sie decken insbesondere Strukturprobleme in den Studienbedingungen wie die Überschneidung von Lehrveranstaltungen, das Ausfallen und die mangelnde inhaltliche Abstimmung von Lehr-

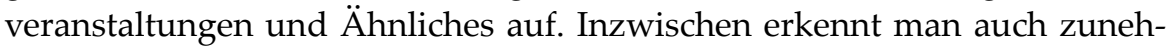
mend, welche Bedeutung die Evaluation der Forschung für eine Fakultät und die Hochschule besitzt.

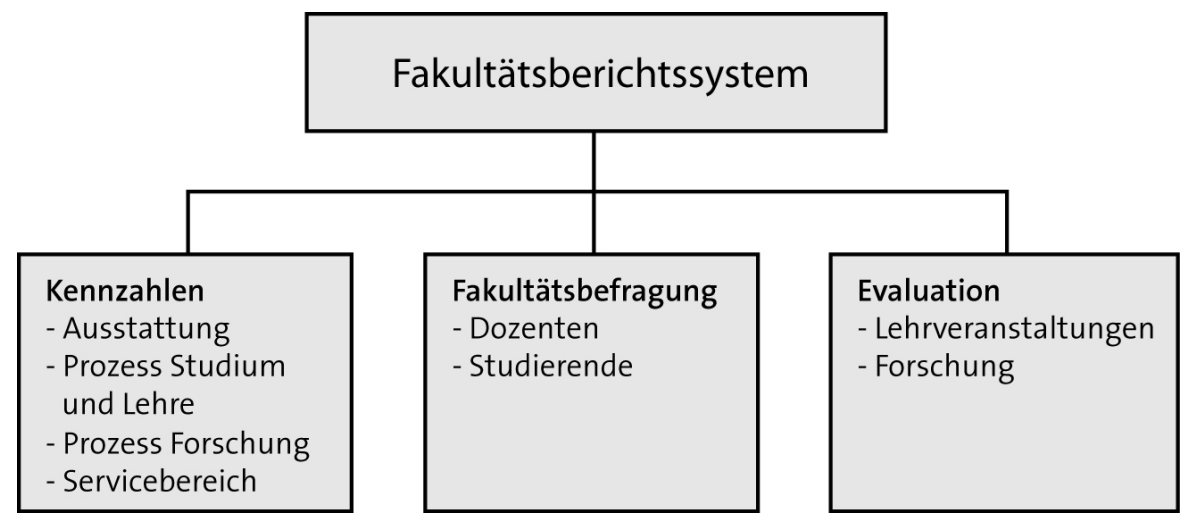

Abbildung 9: Komponenten eines Fakultätsberichtssystems

\footnotetext{
${ }^{25}$ Vgl. z. B. Art. 30 Abs. 2 Nr. 2 BayHSchG 2006.

${ }^{26} \mathrm{Vgl}$. Zboril 1998, S. 131 ff.

${ }^{27}$ Vgl. Schwaiger 2003.
} 
Informationen in einer Hochschule zu Forschung, Studium und Lehre sowie Service werden von vielen Empfängern und für zahlreiche Zwecke benötigt. Deshalb sind sie in Systeme einzustellen, die eine flexible Auswertung ermöglichen. Hierzu bieten sich Data-Warehouse-Systeme an, in denen die Daten der laufenden Anwendungssysteme zum Beispiel für die Studenten- und Prüfungsverwaltung eingehen, die über längere Zeit hinweg gespeichert werden und dadurch Analysen über zeitliche Entwicklungen ermöglichen. So wurde in Bayern vor über einem Jahrzehnt speziell für Hochschulzwecke das Data-Warehouse-System CEUS, das „Computerbasierte Entscheidungs-Unterstützungssystem " ${ }^{28}{ }^{28}$ entwickelt. Mit seiner in Abbildung $10^{29}$ skizzierten Struktur wird ein solches System in Bayern vom Wissenschaftsministerium und den meisten Universitäten genutzt.

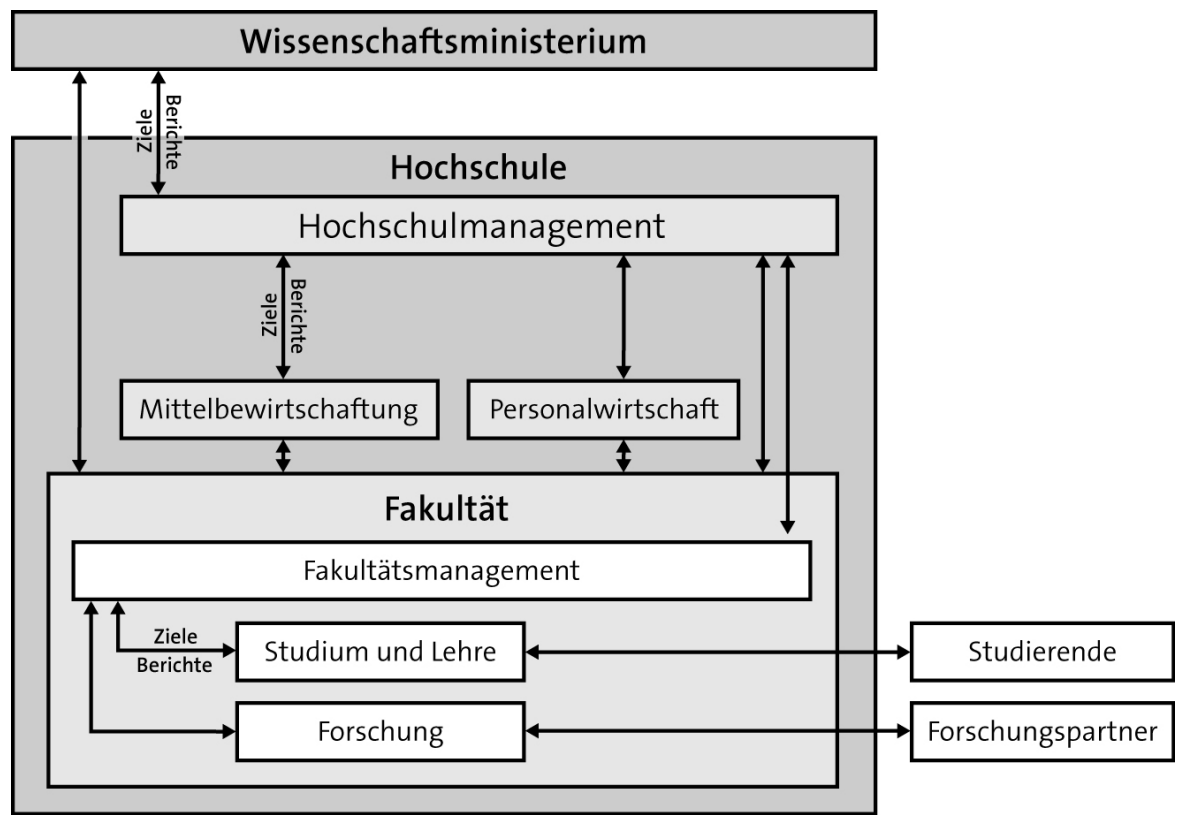

Abbildung 10: Komponenten des Data-Warehouse-Systems CEUS

\footnotetext{
${ }^{28}$ Vgl. Sinz u. a. 1999; Sinz u. a. 2001.

${ }^{29} \operatorname{Sinz}$ u. a. 1999.
} 
Schon nach 1965 gab es intensive Bemühungen, deutsche Hochschulen mit einer eigenständigen Kostenrechnung auszustatten. ${ }^{30}$ Die damaligen Modellversuche wurden letztlich nicht umgesetzt. Erst nach 1990 erkannte man zunehmend, dass die Hochschulen ein eigenes leistungsfähiges Rechnungswesen benötigen. Um ein möglichst einheitliches Vorgehen zu erreichen, gründeten die Kanzler aller deutschen Universitäten den Arbeitskreis „Hochschulrechnungswesen“. Dieser erarbeitete das Konzept für eine Hochschulrechnung ${ }^{31}$, dessen zentrale Elemente 1999 in einer "Greifswalder Erklärung“ der Vollversammlung aller Kanzler niedergelegt wurden. ${ }^{32}$ Darin wird eine Trennung zwischen Grund- und Auswertungsrechnungen empfohlen, um deutlich zu erkennen, welche Größen prüfbare empirische Sachverhalte wiedergeben und welche auf zweckabhängigen Zurechnungen beruhen.

Im Kern sieht das Konzept ein mehrteiliges Rechnungssystem vor. Zu diesem gehören einerseits, wie aus Abbildung 11 ersichtlich, Finanz- sowie Vermögensänderungsrechnung sowie die Bilanz. Diese Komponenten ermöglichen eine finanz- und vermögensorientierte Rechnungslegung und entsprechen dem externen Rechnungswesen erwerbswirtschaftlicher Unternehmungen. Mehr als in diesen wird jedoch die Bedeutung der Finanzrechnung betont, weil Zahlungen die Basis aller monetären Rechnungen bilden, Hochschulen aus einem kameralistischen Rechnungssystem herkommen und häufig darüber noch mit dem Landeshaushalt verknüpft sind. Ein zentraler Unterschied gegenüber dem Rechnungswesen erwerbswirtschaftlicher Unternehmungen liegt darin, dass staatliche Hochschulen keine Erlöse für auf Märkten verkaufte Leistungen erzielen. ${ }^{33}$ Deshalb fehlt ihnen eine klare Erfolgsgröße, deren Erreichung im Rechnungswesen gemessen werden könnte. Aus diesem Grund können sie keine Gewinn- und Verlustrechnung ${ }^{34}$ durchführen; an deren Stelle tritt im Konzept der Universitätskanzler die Vermögensänderungsrechnung, in welcher die Wertänderungen am Vermögen näherungsweise erfasst werden.

\footnotetext{
${ }^{30}$ Vgl. Angermann/Blechschmidt 1972; Wibera 1972; Schweitzer/Hettich 1981.

${ }^{31}$ Vgl. Arbeitskreis Hochschulrechnungswesen 1999; Weichselbaumer 1999.

${ }^{32}$ Vgl. Kronthaler 1999.

${ }^{33}$ Vgl. hierzu Küpper 2000; Küpper 2001; Krützfeld 2007, insbesondere S. 69.

${ }^{34}$ Soweit Hochschulen dennoch (wie z. B. die Universität Heidelberg) Gewinn- und Verlustrechnungen erstellen, sind diese weder für den Erfolg noch für die Einhaltung des Finanzrahmens aussagefähig und insofern irreführend. Vgl. Krützfeld 2007, S. 70 ff. Die Verwendung eines Instruments zur Messung einer Erfolgsgröße, die es überhaupt nicht gibt, dient eher der Verwirrung als der Information.
} 


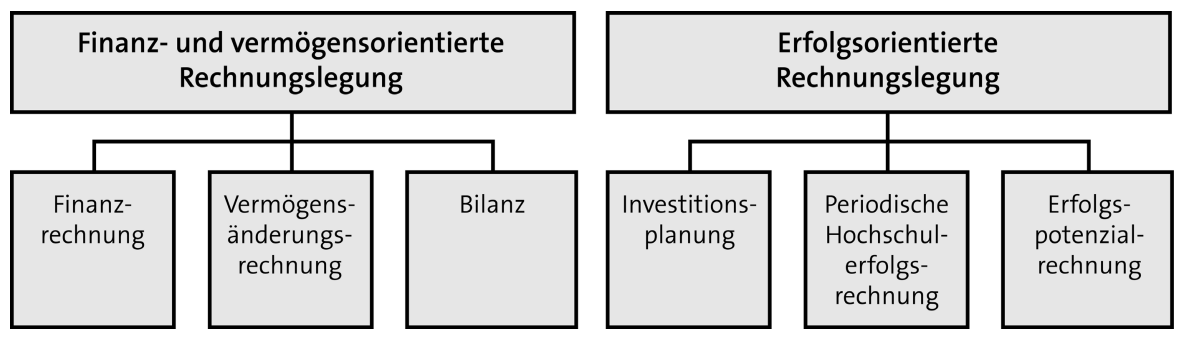

Abbildung 11: Struktur einer ausgebauten Hochschulrechnung

Insbesondere durch die Entwicklungen in der Europäischen Union, die ab 2010 zur ausreichenden Finanzierung von Gemeinkosten bei ihren Drittmittelprojekten Vollkostenkalkulationen ${ }^{35}$ verlangen will, hat die Einrichtung von Kostenrechnungen ${ }^{36}$ hohe Aktualität gewonnen. Sie ist teilweise sogar in den Hochschulgesetzen verankert. ${ }^{37}$ Dabei erscheint wichtig, dass man nicht nur die Kostenseite betrachtet, sondern in die Rechnung auch die vielfältigen, nicht monetär bewerteten Leistungen von Hochschulen eingehen. Dies führt zu einer Periodenerfolgsrechnung, wie sie entsprechend dem Vorschlag des Arbeitskreises Hochschulrechnungswesen in Abbildung 12 skizziert ist.

Die Universitätskanzler haben auch erkannt, dass Hochschulen über Investitionsplanungen verfügen müssten, weil der größte Teil ihrer Mittel auf längere Sicht gebunden wird. Darüber hinaus sollte man die Entwicklung von Rechnungen anstreben, welche das für Hochschulen besonders wichtige Potenzial ${ }^{38}$ in Forschung und Lehre erfassen. In Österreich ist ein solcher Versuch schon unternommen worden. ${ }^{39}$

Dann gelangt man zu den drei in Abbildung 11 wiedergegebenen kurz-, mittel- und langfristigen Komponenten der erfolgsorientierten Rechnungslegung von Hochschulen.

\footnotetext{
${ }^{35}$ Vgl. Küpper 2002 a; Embert/Stich/Götz 2007.

${ }^{36}$ Vgl. Schweitzer/Küpper 2008, insbesondere S. 749 ff.

${ }^{37}$ Vgl. z. B. § 89 Hess. Hochschulgesetz 1998.; Art. 5 Abs. 1 S. 6 BayHSchG 2006.

${ }^{38}$ Vgl. auch Breid 1994; Kemmler 1990.

${ }^{39}$ Vgl. Titscher 2004.
} 


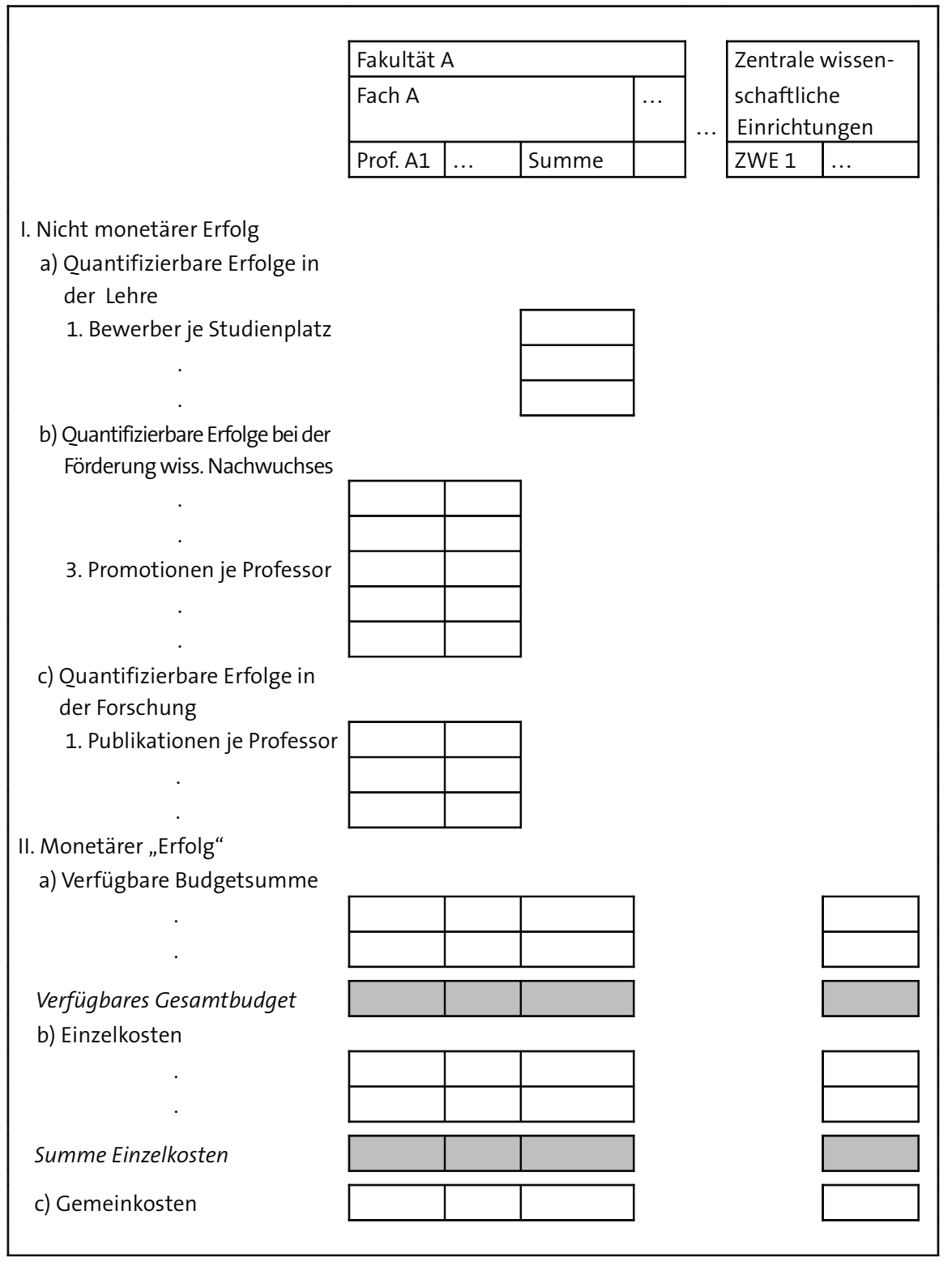

Abbildung 12: Konzept einer universitären Erfolgsübersicht 
Für die Koordination der Führungsteilsysteme einer Hochschule in ihrem Controlling ${ }^{40}$ bieten sich grundsätzlich die gleichen Instrumente wie für die Steuerung der Hochschulen eines Landes an. In vielen Hochschulen wurde die früher übliche Fortschreibungsbudgetierung durch Verfahren der outputbezogenen Budgetierung, eine kennzahlenbasierte Mittelverteilung und Zielvereinbarungen $^{41}$ ersetzt. Einzelne Hochschulen nutzen dabei auch das Instrumentarium der Balanced Scorecard, die man beispielsweise nach den in Abbildung 13 wiedergegebenen vier Dimensionen gliedern kann. Sie unterstützt die Koordination und Steuerung über Ziele ${ }^{42}$ und hilft, diese in Kennzahlen, Vorgaben und Maßnahmen umzusetzen.

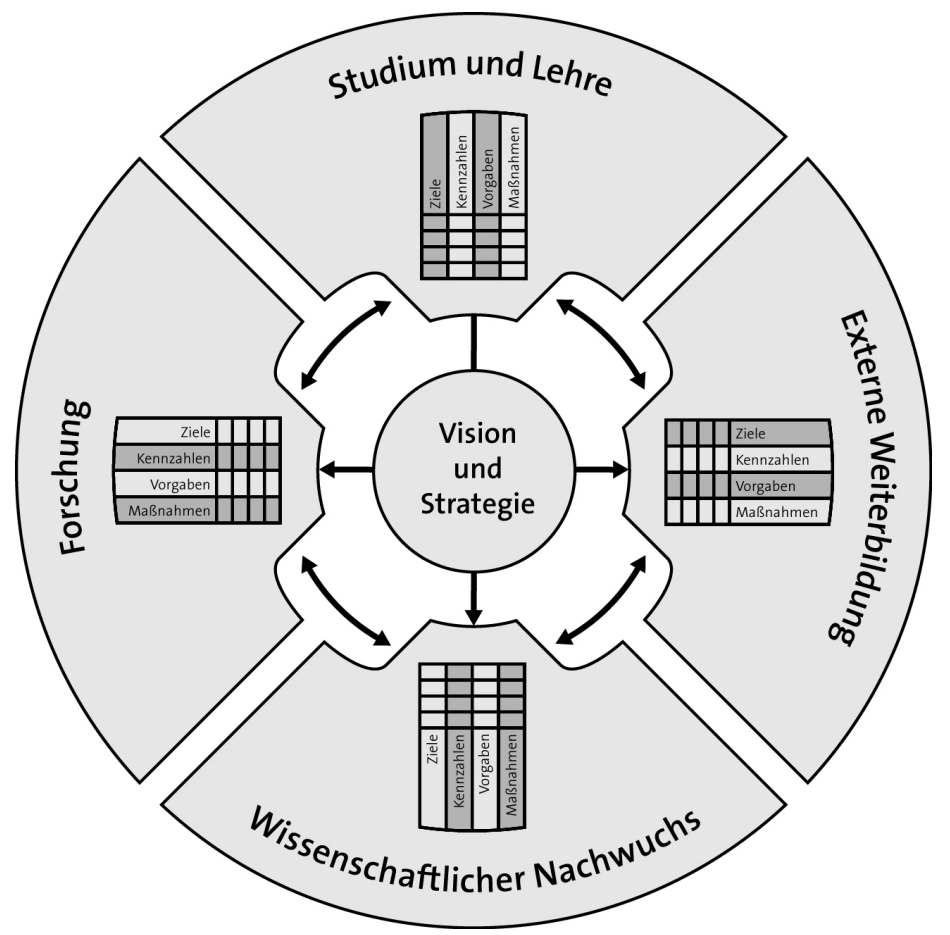

Abbildung 13: Beispiel einer Balanced Scorecard für Hochschulen

\footnotetext{
${ }^{40}$ Vgl. Küpper 1996; Küpper 2008, S. 518 ff.

${ }^{41} \mathrm{Vgl}$. Weichselbaumer 2007.

${ }^{42}$ Vgl. Küpper 2008, S. 416 ff.
} 


\section{Perspektiven für das Hochschulsystem}

Die Analyse macht deutlich, dass in den vergangenen 15 Jahren viel Bewegung in die deutsche Hochschullandschaft gekommen ist. Im Anschluss an die Integration der ehemaligen DDR-Hochschulen und einer Vielzahl von Einzelmaßnahmen zur Verbesserung der Studienbedingungen musste man nach 1995 „auf eine ,strategische' Ebene übergehen [...], [um] entweder die Rahmenbedingungen in Bezug auf Studentenzahlen und Ressourcenausstattung deutlich zu verändern oder einschneidende Strukturreformen durchzuführen" ${ }^{43}$ Es blieb nur der zweite Weg. Von den damals ins Auge gefassten Möglichkeiten „einer breiteren Einführung studienbegleitender Prüfungssysteme („Credit Points“), [...] Übertragung der Auswahlverfahren [...] auf die Universitäten [...], Einführung von Studiengebühren, [...] Ausrichtung der Ressourcenzuteilung an Leistungskriterien, neue[n] Organisationsformen [...] mit einer Dezentralisierung der Kompetenzen bei gleichzeitiger Stärkung der Leistungsorientierung und Verantwortlichkeit $^{\prime \prime 4}$ ist relativ viel auf den Weg gebracht worden. Das lässt es gerechtfertigt erscheinen, von einer zweiten großen Hochschulreform in der Bundesrepublik Deutschland zu sprechen. Neben die hier schwerpunktmäßig betrachteten Änderungen in der Steuerung der Hochschulen treten dramatische internationale Einflüsse auf die Struktur von Forschung und Lehre. $\mathrm{Zu}$ diesen gehören neben dem in Europa vereinbarten Übergang auf ein Bachelor- und Mastersystem insbesondere die Öffnung sowie Diskussion um die Qualifizierungswege zum Universitätslehrer über Habilitation oder Juniorprofessur, ${ }^{45}$ die Veränderung der Bewertungskriterien für Hochschullehrer und Hochschulen mit der besonderen Betonung streng referierter internationaler Publikationen und das Gewicht der Drittmittelforschung.

Aus den Meinungsäußerungen in Politik und Gesellschaft gewinnt man den Eindruck, die hohe Bedeutung der Ausbildung und der Forschung in den Hochschulen für die künftige Position des Landes werde erkannt. Umso wichtiger ist es, welchen Weg sie künftig gehen. Es wäre schlimm, wenn man den Hochschulen 20 Jahre nach der Reform wiederum mangelnde

\footnotetext{
${ }^{43}$ Küpper in: Harnier u. a. 1998, S. 42.

${ }^{44}$ Ebd.

${ }^{45}$ Vgl. Berning/Harnier/Hofmann 2001 sowie Berning/Küpper 2001.
} 
Wettbewerbsfähigkeit vorwerfen und daher zentrale Komponenten auch dieser Reform aufheben müsste.

Die sich jetzt vollziehende Hochschulreform 2000 stellt das deutsche Hochschulsystem vor eine grundsätzliche Frage. Sie hatte einen Ausgangspunkt in der Verbesserung des Führungssystems und der Nutzung betriebswirtschaftlicher Instrumente zur Effizienzsteigerung. Dabei zeigt sich die Gefahr, dass man die aus der Wirtschaft abgeleiteten Instrumente - wie zum Beispiel die Bilanzierung - zu wenig an die Bedingungen der Hochschulen anpasst. Hochschulen, insbesondere staatliche, sind keine erwerbswirtschaftlichen Unternehmungen. Die deutschen Hochschulen kommen aus einer mit dem Namen Humboldt verbundenen Tradition der Verbindung von Forschung und Lehre. Es erscheint nicht zweckmäßig, diese Ausrichtung völlig aufzugeben. Eine "Ökonomisierung" und „Amerikanisierung" dürfte nicht der richtige Weg sein. Vielmehr sind die aus Ökonomie und Internationalisierung kommenden Impulse im zweckmäßigen Maß aufzunehmen und an die, von einer langen Tradition mit eindrücklichen Leistungen geprägten Bedingungen der Hochschulen unseres Landes anzupassen.

\section{Literatur}

Angermann, Adolf; Blechschmidt, Uwe (1972): Hochschulkostenrechnung. Weinheim u. a.

Arbeitskreis Hochschulrechnungswesen der deutschen Universitätskanzler (1999): Schlussbericht. München.

Berning, Ewald; Harnier, Louis v.; Hofmann, Yvette (2001): Das Habilitationswesen an den Universitäten in Bayern. Praxis und Perspektiven. München.

Berning, Ewald; Küpper, Hans-Ulrich (2001): Juniorprofessuren statt Habilitation? Eine Klärung festgetretener Positionen. In: Beiträge zur Hochschulforschung (23), S. 121-141.

Breid, Volker (1994): Erfolgspotenzialrechnung - Konzeption im System einer finanzierungstheoretisch fundierten, strategischen Erfolgsrechnung. Stuttgart. 
Ederleh, Jürgen (1996): Leistungsbezogene Mittelzuweisung. In: Globalhaushalt - Modelle und Erfahrungen. Clausthaler Beiträge zum Hochschulmanagement. Clausthal-Zellerfeld, S. 63-94.

Embert, Uwe; Stich, Andreas; Götz, Wolfgang (2007): Modell zur Berechnung der Kosten für die Bereitstellung eines Studienplatzes. In: Küpper, H.-U. (Hg.): Hochschulrechnung und Hochschulcontrolling, Special Issue 5/2007 der Zeitschrift für Betriebswirtschaft. Wiesbaden, S. 35-58.

Falk, Susanne; Reimer, Maike; Hartwig, Lydia (2007): Absolventenforschung für Hochschulen und Bildungspolitik. Konzeption und Ziele des Bayerischen Absolventenpanels. In: Beiträge zur Hochschulforschung, (29), S. 6.

Falk, Susanne; Reimer, Maike (2007): Verschiedene Fächer, verschiedene Übergänge. Der Berufseinstieg und „frühe“ Berufserfolg bayerischer Hochschulabsolventen. In: Beiträge zur Hochschulforschung, (29), S. 3470 .

Gensch, Sigrid Kristina; Schindler, Götz (2003): Bachelor- und Master-Studiengänge an den staatlichen Hochschulen in Bayern. München.

Harnier, Louis v.; Länge-Soppa, Ricarda; Schüller, Joachim; SchneiderAmos, Ingrid (1998): Studienbedingungen und Studiendauer an bayerischen Universitäten. München.

Hartmann, Yvette (1997): Controlling interdisziplinärer Forschungsprojekte. München.

Kehm, Barbara M.; Teichler, Ulrich (Hg.) (2005): Bachelor- und Master-Studiengänge in ausgewählten Ländern Europas im Vergleich zu Deutschland: Fortschritte im Bolognaprozess. Bonn u. a.

Kehm, Barbara M.; Teichler, Ulrich (2006): Which direction for bachelor and master programmes? A stocktaking of the Bologna process. In: Tertiary Education and Management (TEAM) (12), S. 269-282.

Kemmler, Walter (1990): Controlling für Hochschulen - dargestellt am Beispiel der Universität Zürich. Bern.

Kerst, Christian; Schramm, Michael (2008): Der Absolventenjahrgang 2000/2001 fünf Jahre nach dem Hochschulabschluss - Berufsverlauf und aktuelle Situation, HIS: Forum Hochschule Nr. F 10. Hannover.

Krasny, Erhard; Ziegele, Frank (1997): Das Modellvorhaben zur globalen Steuerung von Hochschulhaushalten in Niedersachsen. Gütersloh. 
Kronthaler, Ludwig (1999): Greifswalder Grundsätze. Weshalb Hochschulen ein modernes Rechnungswesen brauchen. In: Forschung \& Lehre Nr. 11, S. 583 f.

Krützfeld, Tim (2007): Das kaufmännische Rechnungswesen der Universität Heidelberg. In: Küpper, H.-U. (Hg.): Hochschulrechnung und Hochschulcontrolling, Special Issue 5/2007 der Zeitschrift für Betriebswirtschaft. Wiesbaden, S. 59-82.

Küpper, Hans-Ulrich (1996): Struktur, Aufgaben und Systeme des Hochschul-Controlling. In: Beiträge zur Hochschulforschung (18), S. 147-180.

Küpper, Hans-Ulrich (1997): Das Führungssystem als Ansatzpunkt für eine wettbewerbsorientierte Strukturreform von Universitäten. In: Beiträge zur Hochschulforschung (19), S. 123-149.

Küpper, Hans-Ulrich (1998 a): Transformation von Universitäten zu wettbewerbsorientierten Forschungs- und Lehrinstitutionen. In: Becker, Manfred; Kloock, Josef; Schmidt, Reinhart und Wäscher, Gerhard (Hg.): Unternehmen im Wandel und Umbruch. Stuttgart, S. 235-257.

Küpper, Hans-Ulrich (1998 b): Planung und Kontrolle in Universitäten. In: Küpper, H.-U.; Sinz, E. (Hg.): Gestaltungskonzepte für Hochschulen - Effizienz, Effektivität, Evolution. Stuttgart, S. 133-151.

Küpper, Hans-Ulrich (2000 a): Hochschulrechnung auf der Basis von doppelter Buchhaltung und HGB? In: Zeitschrift für betriebswirtschaftliche Forschung (52), S. 348-369.

Küpper, Hans-Ulrich (2000 b): Hochschulen steuern mit kaufmännischem Rechnungswesen - aber richtig! In: Beiträge zur Hochschulforschung (22), S. 217-231.

Küpper, Hans-Ulrich (2001): Rechnungslegung von Hochschulen. In: Betriebswirtschaftliche Forschung und Praxis (6), S. 578-592.

Küpper, Hans-Ulrich (2002 a): Konzeption einer Perioden-Erfolgsrechnung für Hochschulen. In: Zeitschrift für Betriebswirtschaft (72), S. 929-951.

Küpper, Hans-Ulrich (2002 b): Hochschulfinanzierung als Steuerungsinstrument. In: Beiträge zur Hochschulforschung (24), S. 18-43.

Küpper, Hans-Ulrich (2008): Controlling - Konzeption, Aufgaben, Instrumente, 5. Aufl. Stuttgart.

Küpper, Hans-Ulrich (Hg.) (2007): Hochschulrechnung und Hochschulcontrolling, Special Issue 5/2007 der Zeitschrift für Betriebswirtschaft. Wiesbaden. 
Küpper, Hans-Ulrich; Sinz, Elmar (Hg.) (1998): Gestaltungskonzepte für Hochschulen, Effizienz, Effektivität, Evolution. Stuttgart.

Kultusministerkonferenz (2008): Das Bildungswesen in der Bundesrepublik Deutschland 2007. Darstellung der Kompetenzen, Strukturen und bildungspolitischen Entwicklungen für den Informationsaustausch in Europa, bearbeitet von Brigitte Lohmann und Thomas Eckhardt. Herausgegeben vom Sekretariat der Ständigen Konferenz der Kultusminister der Länder in der BRD. Bonn.

Minks, Karl-Heinz; Briedis, Kolja (2005): Der Bachelor als Sprungbrett? Ergebnisse der ersten bundesweiten Befragung von Bachelorabsolventinnen und Bachelorabsolventen. HIS-Kurzinformation A 4. Hannover.

Picht, Georg (1964): Die deutsche Bildungskatastrophe. Analyse und Dokumentation, Freiburg i. Br. 2. unveränderte Aufl. 1965. München.

Reimer, Maike (2008): Wie können Absolventenstudien zum Qualitätsmanagement an Hochschulen beitragen? Erfahrungen des Bayerischen Absolventenpanels. In: Qualität in der Wissenschaft, 1/2008.

Schwaiger, Manfred (2003): Der Student als Kunde - eine empirische Analyse der Zufriedenheit Münchner BWL-Studenten mit ihrem Studium. In: Beiträge zur Hochschulforschung (25), S. 32-62.

Schweitzer, Marcell; Hettich, Günter O. (1981): Entwicklung des Systems einer Kostenarten- und Kostenstellenrechnung an Hochschulen, Schlussbericht zum BLK-Modellversuch. Tübingen.

Schweitzer, Marcell; Küpper, Hans-Ulrich (2008): Systeme der Kosten- und Erlösrechnung, 9. Aufl. München.

Sinz, Elmar (1998): Konzeption der Untersuchungsmethodik. In: Gestaltungskonzepte für Hochschulen, Effizienz, Effektivität, Evolution. Stuttgart, S. 1-9.

Sinz, Elmar J.; Böhnlein, Michael; Ulbrich-vom Ende, Achim (1999): Konzeption eines Data-Warehouse-Systems für Hochschulen. In: Mayr, H. C.; Steinberger, C.; Appelrath, H.-J.; Marquardt, U. (Hg.): Tagungsband zum Workshop „Unternehmen Hochschule“ im Rahmen der „Informatik '99“. Paderborn, S. 111-124.

Sinz, Elmar J.; Böhnlein, Michael; Ulbrich-vom Ende, Achim; Plaha, M. (2001): Architekturkonzept eines verteilten Data-Warehouse-Systems für das Hochschulwesen. In: H.-U.; Huther, A.; Reitwiesner, B. (Hg.): Information Age Economy, Buhl. Heidelberg. 
Titscher, Stefan (2004): Theoretische Grundlagen, Interpretationsvarianten und mögliche Auswirkungen des Universitätsgesetzes. In: Höllinger, S.; Titscher, S. (Hg.): Die österreichische Universitätsreform: Zur Implementierung des Universitätsgesetzes 2002. Wien, S. 73-123.

Waltenberger, Monika (2006): Rechnungslegung staatlicher Hochschulen: Prinzipien, Struktur und Gestaltungsprobleme. München.

Waltenberger, Monika (2007): Rechnungslegung staatlicher Hochschulen. In: Küpper, H.-U. (Hg.): Hochschulrechnung und Hochschulcontrolling, Special Issue 5/2007 der Zeitschrift für Betriebswirtschaft. Wiesbaden, S. 1-33.

Weichselbaumer, Jürgen (1999): Hochschulrechnungswesen im Wandel. Entwicklungen, Bestandsaufnahme, Perspektiven. In: Beiträge zur Hochschulforschung (21), S. 279-293.

Weichselbaumer, Jürgen (2007): Hochschulinterne Steuerung über Zielvereinbarungen - ein prozessbegleitender ökonomisch-methodischer Ansatz an der TU München. In: Küpper, H.-U. (Hg.): Hochschulrechnung und Hochschulcontrolling, Special Issue 5/2007 der Zeitschrift für Betriebswirtschaft. Wiesbaden, S. 157-171.

Wibera (1972): Kostenrechnung in Hochschulen. Gutachten der Wibera Wirtschaftsberatungs AG im Auftrag des Ministers für Wissenschaft und Forschung des Landes Nordrhein-Westfalen. Düsseldorf.

Wissenschaftsland (2005): Wissenschaftsland Bayern 2020; Empfehlungen einer internationalen Expertenkommission. München.

Wissenschaftsrat (Hg.) (2002): Eckdaten und Kennzahlen zur Lage der Hochschulen von 1980 bis 2000. Köln.

Witte, Johanna (2006 a): Die deutsche Umsetzung des Bologna-Prozesses. In: Aus Politik und Zeitgeschichte (48), S. 21-27.

Witte, Johanna (2006 b): Change of Degrees and Degrees of Change: Comparing Adaptations of European Higher Education Systems in the Context of the Bologna Process. Enschede.

Zboril, Nicole A. (1998): Fakultäts-Informationssystem als Instrument des Hochschul-Controllings. Stuttgart. 


\section{Das letzte Wort}

Wolfgang Weber

Zunächst muss ich gestehen: Die Formulierung „Das letzte Wort“ ist ein Plagiat. Ich habe diese Formulierung aus dem Verabschiedungsprogramm von Professor Müller-Böling übernommen. Ich vermute aber, dass ich mit der Ankündigung „Das letzte Wort“ so vielen Leuten in Hamburg eine wirkliche Freude mache, dass ich nicht widerstehen konnte, diese Formulierung zu übernehmen.

Es ist mir ein großes Anliegen, mich im Namen aller früheren Dekanatsmitglieder sehr herzlich für vieles zu bedanken, das uns während unserer Amtszeiten widerfahren ist. Ich bedanke mich

- für dieses hochkarätig besetzte Symposium; dabei gilt der Dank der Referentin und den Referenten, den Organisatoren der Veranstaltung und allen Anwesenden,

- bei den Mitgliedern aller Gremien in der Fakultät, insbesondere den Mitgliedern des Fakultätsrates, für die stets gute und an den Sachfragen orientierte Zusammenarbeit,

- bei den fünf anderen Fakultäten und deren Leitungen, die auch bei diesem Anlass prominent vertreten sind, für die hervorragende Zusammenarbeit,

- bei den beiden Präsidien und der Verwaltung der Universität Hamburg für das gemeinsame, am Wohl der Universität orientierte Ringen um die besten Lösungen; ich freue mich besonders, dass es sich Altpräsident Lüthje nicht hat nehmen lassen, heute mit dabei zu sein,

- bei den über 400 Mitarbeiterinnen und Mitarbeitern der Fakultät für ihren Einsatz.

Es war eine großartige Idee unserer Nachfolger, diese erste Phase des Lebens der neuen und großen Fakultät Wirtschafts- und Sozialwissenschaften mit einem Symposium zum Hochschulmanagement abzuschließen. Dafür 
bedanken wir uns sehr herzlich. Durch diese Veranstaltung wird noch deutlicher, wie wichtig dieses Thema ist.

Das Thema des Symposiums steht einer Fakultät besonders gut an, die über ein Center for Globalization and Governance verfügt und in der die Untersuchung und Erörterung von Managementfragen eine Heimat hat.

Gestatten Sie mir einen kurzen Exkurs zum Thema des Symposiums, der mit Feststellungen beginnt, die in einer Einführung in die Betriebswirtschaftslehre im ersten Semester angesiedelt sind: Die Aufgabenbereiche, die mit der Steuerung und Lenkung von Organisationen $\mathrm{zu}$ tun haben, werden üblicherweise unter der Bezeichnung Management zusammengefasst. Dabei wird das Wort Management in zweifacher Weise verwendet:

- Management als Funktion beschreibt die Teilaufgaben, die im Zusammenhang mit der Steuerung und Lenkung von Organisationen zu tun haben beziehungsweise von den Organisationen zu bewältigen sind;

- Management als Institution bezeichnet die Personen beziehungsweise die Personengruppen, die Management-Aufgaben wahrnehmen.

Bei dieser Veranstaltung wurden beide Perspektiven angesprochen. Sie sind eng miteinander verknüpft.

Die Gründungsphase der WiSo-Fakultät wurde begleitet von Ergebnissen der Management-Forschung. Dass wir überhaupt auf einschlägige und verwertbare Ergebnisse dieses Forschungszweigs zurückgreifen können, verdanken wir zu einem beachtlichen Teil Professor Müller-Böling. Wir freuen uns, dass Sie heute an dieser Veranstaltung mit vielen wichtigen Diskussionsbeiträgen teilgenommen haben. Sie haben viele Fragen frühzeitig thematisiert und im Verband der Hochschullehrer für Betriebswirtschaft die Einrichtung der wissenschaftlichen Kommission Hochschulmanagement eingeleitet, an deren späterer Arbeit Sie sich äußerst aktiv beteiligt haben.

Eine der wenigen Professuren auf diesem Gebiet hat Frau Kollegin Sporn an der Wirtschaftsuniversität Wien inne. Als derzeitige Vizerektorin sind Sie allerdings vorrangig mit der praktischen Umsetzung von Erkenntnissen der Hochschulmanagementforschung befasst. Alle Kollegen, die hier Beiträge geleistet haben, sind ihrem Thema von ihrem jeweils eigenen wissenschaftlichen Betätigungsfeld näher gekommen. Das gab dieser Veranstaltung ihr besonderes Profil: Hier haben Wirtschafts- und Sozialwissen- 
schaftlerinnen und -wissenschaftler referiert und Beiträge geleistet, die in unseren Disziplinen, die wir in der Fakultät pflegen, verwurzelt sind.

Ich erlaube mir auch einige Worte zu mir selbst. Auch wenn ich mich jetzt offiziell im Ruhestand befinde, habe ich vor, mich weiterhin auf dem Feld des Hochschulmanagements zu tummeln. Ich werde versuchen, meinen wissenschaftlichen Hintergrund - die Wirtschaftswissenschaften und insbesondere die Organisationstheorie - mit den praktischen Erfahrungen in unterschiedlichen Rollen des Hochschulmanagements zu kombinieren und den einen oder anderen Beitrag zu diesem Themenkomplex zu leisten.

Ich werde außerdem für eine überschaubare Zeit bei Leaders-In-Science, einer Personalberatungs-Initiative des Deutschen Hochschulverbandes, versuchen, bei der qualifizierten Besetzung von Positionen im Hochschulmanagement mitzuwirken.

Diese Planung erleichtert es mir, jetzt auf längere Ausführungen zur Hochschulgovernance beziehungsweise zum Hochschulmanagement zu verzichten. Ich erlaube mir jedoch einige wenige Anmerkungen hierzu.

Eine der spannenden Fragen ist, ob sich in Deutschland und seinen mitteleuropäischen Nachbarländern Karrieren im Hochschulmanagement herausbilden und so etwas wie ein neuer Berufszweig entsteht. Nach meinen Beobachtungen sind wir bereits deutlich erkennbar auf diesem Weg. Schon jetzt ist bereits die Gefahr des Auseinanderdriftens verschiedener Zielvorstellungen zu erkennen. Diesen Zielkonflikt möchte ich mit dem Begriffspaar Verwaltungseffizienz versus wissenschaftliche Effizienz kennzeichnen.

Die Beiträge dieses Symposiums spiegeln dieses Konfliktfeld in sehr anregender Weise wider. Der Politikwissenschaftler Friedbert Rüb deutete dieses Problem an, als er Governance mit der Formulierung „andere bei der Arbeit stören" illustrierte. Rolf v. Lüde, Soziologe und Wirtschaftswissenschaftler, unterschied zwischen einem normativen und einem analytischen Governance-Begriff und stellte den Gedanken der Integration - das Zusammenwirken aller oder wenigstens vieler, die am Wissenschaftsprozess beteiligt sind - in den Mittelpunkt seiner Überlegungen. Dabei kennzeichnete er den Konflikt zwischen den verschiedenen Modellen der Universität. Barbara Sporn, Wirtschaftswissenschaftlerin und Professorin für Hochschulmanagement, umriss Fragen des Handelns von Universitäten unter sich ändernden Rahmenbedingungen am österreichischen Beispiel und illustrierte dabei die Konfliktfelder anschaulich, die sich bei der An- 
wendung von Steuerungsregeln im Spannungsfeld von zunehmender Hochschulautonomie und Vorbehalten bei der Übertragung von Kompetenzen auftun. Der Beitrag von Ernst Buschor aus Schweizer Perspektive zeigte deutliche Unterschiede in der Finanzierung der deutschen und österreichischen Universitäten einerseits und der Schweizer Universitäten andererseits: Ein enger Zusammenhang zwischen der guten Finanzierung der Hochschulen in der Schweiz und der Qualität der Ausbildung ist nicht zu übersehen. Das New Public Management führt zu mehr Autonomie im Handeln der Universitäten, die bei guter finanzieller Ausstattung den Konflikt zwischen Verwaltungseffizienz und wissenschaftlicher Effizienz im Ansatz auflösen. Der niederländische Kollege Roosendaal beleuchtete die Wettbewerbsposition und das strategische Handeln in Unternehmen und in Universitäten sowie das Spannungsfeld Zentralisation - Dezentralisation von Entscheidungskompetenzen. Es spräche nichts dagegen, dass sich Universitäten an den in Unternehmen bewährten Handlungsmodellen orientierten. Die betriebswirtschaftliche Perspektive leitete auch die konzeptionellen Überlegungen von Hans-Ulrich Küpper, der strategische Perspektive und instrumentelle Umsetzung zu einem konkreten Handlungsvorschlag zusammenführt.

Damit schließt sich der Kreis. Ich bin beim Dank für die informativen und anregenden Beiträge angelangt. Das Symposium bezog seine Spannung einerseits aus der Tatsache, dass die Referentin und die Referenten aus vier Ländern mit jeweils unterschiedlichen Umfeldern kamen, aus den Niederlanden, aus Österreich, der Schweiz und aus Deutschland. Es bezog Spannung aber auch aus dem Faktum, dass eine sozialwissenschaftliche Sichtweise einer wirtschaftswissenschaftlichen Perspektive mit organisationstheoretischen und instrumentellen Anklängen gegenübergestellt wurde.

Gestatten Sie mir, dass ich zum Abschluss meine beziehungsweise unsere gemeinsamen drei Jahre Dekanatsarbeit in der Gründungsphase der Fakultät beleuchte. Ich kann dies in wenigen Sätzen zusammenfassen:

Die Aufgabe des Zusammenführens zweier Fachbereiche der Universität Hamburg und der bis dahin selbstständigen Hamburger Universität für Wirtschaft und Politik war für alle Beteiligten eine große Herausforderung. Wenn man Spaß an der Bewältigung solcher Herausforderungen hat, war dies genau die richtige Aufgabe.

Statt einer detaillierten Beschreibung der Befindlichkeiten an den rund 1000 Arbeitstagen - viele Wochenenden und angebliche Urlaubstage einge- 
rechnet - möchte ich mein Fazit wie folgt ziehen: Es gab praktisch an jedem Tag Ärger. Aber ich bin jeden Tag gerne an meinen Arbeitsplatz im Dekanat gegangen. Mit anderen Worten: Die Arbeit hat Freude gemacht. Was will man mehr? Ich habe den Eindruck, dass alle Mitglieder des Leitungsgremiums dieser Fakultät zu einem ähnlichen Ergebnis kommen.

Wenn die, die nach der ersten Dekanats-Crew kamen beziehungsweise kommen, ein ähnliches Fazit ziehen, wäre das ein gutes Ergebnis. Ich wünsche es unseren Nachfolgerinnen und Nachfolgern auf jeden Fall.

Dass wir Spaß an unserer Arbeit hatten, zeigte sich darin, dass wir innerhalb und außerhalb der weit über 100 Dekanatssitzungen viel gelacht haben - manchmal zwar bitter, meistens aber in fröhlicher Bewältigung der uns auferlegten Aufgaben.

Von den Aufgaben, die uns übertragen wurden und denen wir uns gestellt haben, konnten wir das meiste schaffen: Die Fakultät hat über ihre künftige Struktur entschieden, und sie hat einstimmig ihre Satzung beschlossen. Leider haben wir nicht alles geschafft, was wir uns vorgenommen hatten. Aber Frau Frost, Herr Rüb, Herr Bassen, Herr Nell, Herr Flieger wären uns vermutlich böse, wenn wir ihnen nichts zur Bewältigung übrig gelassen hätten.

Darüber, was noch zu tun ist und wie es weitergehen soll, kann nach der Planung dieser Veranstaltung jetzt in Kleingruppen auf dem Flur gesprochen werden. Die Veranstalter dieses Symposiums, in deren Namen ich jetzt sprechen darf, laden Sie zu einem kleinen Imbiss und zu zwanglosen Gesprächen ein.

Allen, die diese Veranstaltung möglich gemacht haben, sie vorbereitet oder heute auf dem Podium Beiträge geleistet haben, darf ich nochmals sehr herzlich danken: besonders Dr. Wolfgang Flieger, dem Geschäftsführer der Fakultät, Herrn Prodekan Friedbert Rüb, Frau Zimmermann und nochmals Ihnen allen für Ihre Anwesenheit und Thre rege Beteiligung an der Diskussion.

Dass dieses Symposium im Vorfeld einiges versprach, können Sie daran erkennen, dass Teilnehmer nicht nur aus Hamburg, sondern unter anderem auch aus Dortmund, Kiel, Hannover, Tübingen oder Stuttgart kamen. Ich wünsche sehr, dass die Wirkungen dieser Veranstaltung weit über Hamburg hinausgehen. 

Veranstaltungsprogramm

Symposium „Hochschulmanagement - neue Wege der Hochschulgovernance“

Donnerstag, 16. Oktober 2008

12.45-13.15 Uhr Kaffee-Empfang

13.15-13.45 Uhr Begrüßung und Eröffnung

Prof. Dr. Friedbert W. Rüb,

Forschungsdekan der WiSo-Fakultät, UHH

anschließend:

„Neue Governance der Wissenschaft"

Prof. Dr. Rolf v. Lüde,

Institut für Soziologie, Fachbereich Sozialwissen-

schaften,

Forschungsdekan der WiSo-Fakultät, UHH, bis

Februar 2008

13.45-15.30 Uhr „Die Steuerung autonomer Universitäten: Erfahrungen mit der österreichischen Universitätsreform“ Prof. Dr. Barbara Sporn,

Vizerektorin für Forschung, Internationales und External Relations, Wirtschaftsuniversität Wien anschließend:

„Das Schweizer Hochschulrecht vor der Novellierung"

Prof. Dr. oec. Ernst Buschor,

Mitglied der Regierung des Kantons Zürich (19932003), Vizepräsident der Schweizer Universitätskonferenz (2001/02) und ehemaliger Vizepräsident des Rates der Eidgenössischen Technischen Hochschulen (ETH)

15.30-16.00 Uhr Pause 
$16.00-17.45 \mathrm{Uhr}$ „The central-decentral paradox:

The university as a merging organization"

Prof. Dr. Hans Roosendaal,

Professor for Strategic Management, University of

Twente/Niederlande

anschließend:

„Moderne Steuerungsinstrumente für Hochschulen"

Prof. Dr. Hans-Ulrich Küpper,

Ludwig-Maximilian-Universität München, Leiter des Bayerischen Staatsinstituts für Hochschulforschung und Hochschulplanung

17.45-18.00 Uhr „Das letzte Wort“

Prof. Dr. Dr.h. c. Wolfgang Weber,

Gründungsdekan der WiSo-Fakultät, $U H \mathrm{H}$, bis

31. März 2008

18.00 Uhr

Buffet und Gelegenheit zum persönlichen Gedankenaustausch 


\section{Beitragende}

Hans-Ulrich Küpper, Prof. Dr. Dr. h. c., Institut für Produktionswirtschaft und Controlling, Ludwig-Maximilians-Universität München, und Leiter des Bayerischen Staatsinstituts für Hochschulforschung und Hochschulplanung

Rolf v. Lüde, Prof. Dr., Institut für Soziologie, Fachbereich Sozialwissenschaften, Forschungsdekan der WiSo-Fakultät der Universität Hamburg im Gründungsdekanat bis Februar 2008

Hans E. Roosendaal, Prof. Dr., Professor for Strategic Management, University of Twente/Niederlande

Barbara Sporn, Prof. Dr., Vizerektorin für Forschung, Internationales und External Relations, Wirtschaftsuniversität Wien

Wolfgang Weber, Prof. Dr. Dr. h. c. Dr. h. c., Gründungsdekan der WiSo-Fakultät der Universität Hamburg bis 31. März 2008

Kasia Zalewska-Kurek, Dr., School of Business, Public Administration and Technology, University of Twente/Niederlande 
Das Ende der Gründungsphase der Fakultät Wirtschafts- und Sozialwissenschaften mit der Integration der bis dahin selbstständigen Hamburger Universität für Wirtschaft und Politik (HWP) sowie der bisherigen Fachbereiche Wirtschaftswissenschaften und Sozialwissenschaften der Universität Hamburg war Anlass zu einem wissenschaftlichen Symposium zur Hochschulgovernance mit hochkarätiger Besetzung. Ziel war es, unterschiedliche Management-Modelle, vor allem aus dem europäischen Ausland, einander gegenüberzustellen und diese sowohl aus einer erfahrungsbasierten Leitungsperspektive als auch unter wissenschaftlich-analytischen Sichtweisen zu analysieren und zu bewerten. Ein besonderer Aspekt lag auf dem für alle Universitäten relevanten Spannungsverhältnis von Zentralität und Dezentralität. Die gehaltenen Vorträge werden in diesem Band dokumentiert.

ISBN 978-3-937816-73-9 